\title{
RESUMO DAS PRELECÇÕES DE DIREITO
}

\author{
INTERNACIONAL PUBLICO.
}

\section{Ponto $1 .^{\circ}$}

Noção de Direito Internacional. O Direito INternacional E a falta de coacÇão. Fundamento do Direito InTERnACIONAL.

A diversidade de definições de Direito Internacionạl é devida á addição de caracteristicos ou desnecessarios para determinar a idéa, ou meras exigencias de escolas de seus autores (Lafayette, p. 2).

$\mathrm{E}^{\prime}$, pois, inutil enumerar as diversas definições do Direito das Gentes, como fazem muitos autores. Basta-nos a noção dada por Oppenheim, para termos uma comprehensão clara da matéria.

A definição de Oppenheim. Diz o eminente professor de Cambridge:

"Law of Nations or International Law (Droit des Gens, Volkerrecht) is the name for the body of costumary and conventional rules which are considered legally binding by civilised states in their intercourse with each other (Internacional Law, p. 1 v. $1^{\circ}$ )"

"Direito Internacional é o corpo de regras costumeiras e convencionaes, consideradas legalmente obrigatorias pelos estados civilizados em suas relações reciprocas" 


\section{DIVISÃO}

O Direito Internacional é universal, geral ou particular. A parte das regras costumeiras e convencionaes, consideradas legalmente obrigatorias, que constituem o Direito das Gentes, respeitadas em todos os paizes civilizados sem excepção, eis o que se denomina Direito Internacional Universal. Por exemplo, o direito de legação.

A parte dessas regras obrigatoria para um grande numero de Estados, incluindo grandes potencias, constitue o Direito Internacional Geral, que tende a tornar-se Universal.

A parte dessas regras, finalmente, obrigatorias, sómente para dois ou mais Estados é o que se chama $D i$ reito Internacional particular.

\section{SYNONIMIA}

E' bom advertir que as expressões Direito Internacional e Direito das Gentes são synonimas (Lafayette, p. 2 ; Foignet, p. 1; Bonfils, p. 2; Despagnet, p. 41).

Nys (Direito Internacional), na p. 61, explica que essas expressões são synonimas, mas que alguns autores tentaram distinguil-as. Para elles, o Direito das Gentes, ensinaria a regra que deveria ser observada, o Direito Internacional, ensinaria a regra que é observada na realidade (Denis C. Heron, 1860).

Mas essa distincção não foi adoptada e os escriptores empregam indifferentemente as duas expressões.

Marcel Moye, o insigne professor de Montpellier, denomina o seu trabalho - Droit des Gens Moderne.

No Brasil, como ensina Clovis Bevilaqua (I p. 19), tem-se usado, indistinctamente, das duas expressões. $\mathrm{O}$ dec. de 25 de Novembro de 1826, que nomeou o Commendador 
Biancardi plenipotenciario para o Congresso do Panamá falou de principios luminosos do Direito das Gentes e Publico Universal.

A lei de 11 de Agosto de 1827, creando os cursos juridicos, em S. Paulo e Olinda, instituiu uma cadeira de Direito Natural Publico, analyse da Constituição do Imperio, Direito das Gentes e Diplomacia.

Essas palavras se reproduzem nos estatutos approvados pelo dec. de 7 de Novembro de 1831. Segundo' os estatutos de 1894 (dec. n. ${ }^{\circ} 1386$ de 28 de Abril), na primeira cadeira de 2. ${ }^{\circ}$ anno das Faculdades de Direito, devia ensinar-se, alem de outras materias, o Direito das Gentes. 0 dec. de 19 de Abril de 1879, falla em Direito das Gentes e da mesma designação se serve o dec. n. $1232 \mathrm{~F}$. de 2 de Janeiro de 1891. A lei n. ${ }^{\circ} 314$ de 30 de Outubro de 1895, o Codigo do Ensino, e o dec. 11.530, usam da expressão Direito Internacional.

O dec. 16.782 A, de 13 de Janeiro de 1925, falla em Direito Publico Internacional.

O DIREITO INTERNACIONAL E A FALTA

DE COACÇÃO

Muitos autores têm negado a existencia do Direito Internacional ou, pelo menos, a sua autoridade effectiva.

Diversas objecções têm sido feitas contra a sua existencia, sendo as seguintes as mais importantes:

a) falta de uma lei internacional.

b) falta de um tribunal internacional.

c) falta de força publica encarregada de o fazer respeitar. 


\section{$1 .^{\mathrm{a}}$ OBJECÇÃO}

A primeira objecção responde-se com Bonfils e Cru. chaga, que não é a mesma coisa lei e Direito. Póde não existir uma lei, e existir um Direito Internacional. A lei nada mais é do que a traducção ou transcripção do Direito, é o Direito preexistente que adquire uma forma official. Todos os codigos nasceram depois do funccionamento de regras de Direito. Poderá ser mais debil o Direito que não é consagrado officialmente em lei, mas não quer isso dizer que não exista e não tenha autoridade effectiva, como observa Phillimore.

Dentro da communhão nacional, dizem os negadores do Direito das Gentes, os costumes com o tempo chegam a ser consagrados em lei, ha uma autoridade que promulga os codigos, mas quem legisla, quem dá forma aos costumes na sociedade dos estados?

Realmente o Direito Internacional é, na sua maior parte, costumeiro, mas, ao lado delle, depois do sec. XIX, surge o Direito das Gentes convencional, com uma importancia extraordinaria. Demais, dentro em pouco, os Estados organizados terão como orgão da sociedade das nações os 3 poderes: legislativo, executivo e judiciario.

Por emquanto, os Estados não têm nenhum poder uns sobre outros, sendo o Direito Internacional um direito "between", entre os Estados, e não "above", sobre os Estados. Comtudo os Estados submettem-se ás regras do Direito Internacional pelo consentimento commum.

\section{$2 .^{2}$ OBJECÇÃo}

Esta não tem a menor importancia. Por não haver tribunal não se segue que não haja Direito. Demais, ha tribunaes internacionaes. $\mathrm{O}$ arbitramento é verdadeira- 
mente a submissão de uma contenda a um tribunal. As decisões sobre presas são outro exemplo. Alem do Tribunal Permanente de Arbitragem de Haya e do Tribunal Internacional de Presas, temos o Tribunal Permanente de Justiça Internacional, creado em virtude do Pacto da Liga das Nações (art. 14), de que fallaremos mais detalhadamente.

\section{3. ${ }^{\mathrm{a}}$ OBJECÇÃO}

Déi resposta à esta objecção no meu trabalho: concilia-se a existencia do Direito Internacional com a falta dc coacção por parte do poder publico, trabalho cuja leitura é muito proveitosa aos alumnos da cadeira (v. Revista da Faculdade, 1913 vol. XXI).

\section{RECONHECIMENTO DA AUTORIDADE DO DIREITO INTERNACIONAL PELOS ESTADOS}

Essas questões são somente theoricas. Unicamente a theoria contesta a existencia do Direito das Gentes, pois a prática nunca se recusou a reconhecer a sua autoridade. $\mathrm{Na}$ pratica internacional, os Estados่ sempre reconheceram a sua força, a obrigatoriedade de seus principios, expressa ou tacitamente.

O governo inglez, respondia, em 1763, ao governo Prussiano: "O Direito das Gentes é fundado na justiça, na equidade, na conveniencia e na razão das coisas, e confirmado por prolongado uso"

Veja-se tambem, em Fioré (1. 1. p. 138) e Martens (Recueil des Traités conclus par la Russie avec les Puissances étrangères 1 p. 178), a nota dirigida pela Russia ás potencias alliadas sobre as atrocidades praticadas pelos turcos na Servia. 


\section{O DIREITO INTERNACIONAL E OS CONGRESSOS}

O Direito das Gentes tambem foi sempre reconhecido como obrigatorio pelos congressos e conferencias.

$\mathrm{Na}$ decl. de Aix la Chapelle, de 15 de Novembro de 1818, os contractantes se obrigaram a nunca se separarem dos principios do Direito das Gentes.

Da mesma forma o Trat. de Pariz de 1856, o celebrado entre a França, os Estados Unidos e a Inglaterra em 8 de Maio de 1871 (caso do Alabama) e o de 7 de Março de 1831, entre o Chile e os Estados Unidos, rèconhecem tambem a força obrigatoria das regras de Direito Internacional.

Ainda mais, não só os Estados reconhecem a obrigatoriedade dos principios de Direito Internacional, como ainda fazem os seus tribunaes civis e criminaes, os seus funccionarios e os seus subditos respeitar as regras do Direito das Gentes.

O Direito Internacional e a opinião publica mundial

Quando um estado viola os principios do Direito das Gentes, a opinião publica mundial estigmatiza o seu procedimento, como se fosse a violação de uma lei pura e simples.

E sendo o Direito Internacional baseado no consentimento commum dos membros da communhão internacional, vê-se que elle é um Direito obrigatorio como qualquer outro.

Os tratados sobre correios, telegraphos, etc., repousando sobre o Direito das Gentes, ainda vêm confirmar a obrigatoriedade dos seus preceitos. 


\section{Violações dos principios de Direito das Gentes}

Os principios de Direito Internacional são violados frequentemente, mas os Estados que os violam são os primeiros a justificar o seu procedimento, lançando mão das proprias regras do Direito das Gentes.

Nunca se viu um povo proclamar que violou conscientemente as regras de Direito Internacional. Pelo contrario, procuram sempre os Estados que o violam, interpretal-o, affirmando que se submetteram aos seus principios. Demais, toda violação do Direito Internacional é fatal ao Estado que a pratica.

\section{RESUMO}

Resumindo: as objecções que, desde Hobbes e Pufendorff até Austin se fázem contra a existencia do Direito Internacional não resistem a um exame attento. Pouco importa que o Direito Internacional seja, na sua maior parte, costumeiro: nunca existiu povo que tivesse unicamente direito escripto (Phillimore, Oppenheim).

Por não existir um corpo de leis internacionaes, por não haver tribunal internacional, não é que o Diretto das Gentes deixaria de existir.

Emquanto houver relações de Estado a Estado, haverá um Direito que as reja juridicamente.

Fundamento do Direito Internacional. Grocio (1583-1645) baseia o Direito Internacional numa lei na- 
tural, imposta pela natureza humana e no instincto social. Essa lei natural existe independentemente da intervenção divina (De Jure - Prolegomena, lib. I cap. I) .

Pufendorff (1632 e 1694) acha que essa lei natural é imposta pela Providencia, e que o instincto social foi dada como um meio de defesa para realizar os fins da creação (Law of Nature and Nations, L. I cap. 2). Ambos, Grocio e Pufendarff, concordam em que a lei natural prohibe actos prejudiciaes á vida social.

Thomasio (1655-1728) funda o Direito das Gentes na maxima: "Não faças a outrem o que não queres que te façam a $t i "$

Wolff (1696-1764), funda-o na natureza humana, na tendencia para a perfeição, e nos direitos fundamentaes.

Kant, o grande philosopho, toma por base o principio de liberdade.

Ora, essas theorias são completamente metaphýsicas e porisso não as criticaremos.

Expliquemos, pois, a theoria positiva, realista, a doutrina de Oppenheim.

\section{Fundamento segundo}

\section{OPPENHEIM}

O excelso internacionalista Oppenheim, saudoso professor de Cambridge, define o Direito da seguinte forma: " é um corpo de regras para a conducta humana dentro de uma communhão social, que, por consentimento commum dessa communhão podem ser sanccionadas por um poder exterior" (International Law, I, p. 6).

Por conseguinte o consentimento commum é a base de toda lei, o fundamento do Direito. 


\section{CARACTERISTICOS DAS REGRAS OU NORMAS JURIDICAS}

As regras moraes applicam-se á consciencia e á consciencia unicamènte. Um acto de caridade perderia toḍo o merito se não fosse perfeitamente livre. Ao contrario, uma regra juridica caracteriza-se por poder, em caso de necessidade, ser sanccionada por uma força exterior. A sanç̧ão não é pois indispensavel á existencia do Direito, a coaç̧ão não é portanto a sua caracteristica.

Vejamos a formação das leis.

Pelo consentimento commum, na Inglaterra o Parlamento é competente para legislar. Mas, porque tem força obrigatoria uma lei emanada do Parlamento inglez? Porque, atraz delle, está o consentimento commum do povo inglez, expresso por meio do Direito não escripto.

Dahi poderemos concluir com Oppenheim: "Thus the very important fact comes to light that all statute or written law is based on unwritten law in so far as the power of Parliament to make statute law is given to Parliament by unwritten law" E' pelo consentimento commum do povo inglez que o Parlamento tem a faculdade de fazer leis, que podem ser sanccionadas por um poder exterior. $\mathrm{E}$ ainda, ao lado das leis feitas pelo Parlamento, existem, e, constantemente, dia a dia, crescem e augmentam, outras normas costumeirás ou não escriptas, reconhecidas quotidianamente pelos tribunaes.

O consentimento commum. Mas, que significa consentimento commum?

Si significasse que todo e qualquer membro de uma sociedade devesse dar esse consentimento commum a todo o momento, si significasse que, em qualquer momento, qualquer membro de uma communhão social pudesse negar, ou tivesse de dar o seu consentimento para haver lei. esse 
consentimento commum nunca existiria. Os individuos, membros de uma sociedade, nascem nella, nella crescem, desenvolvem a sua actividade, e nella morrem dando logar a outros.

A sociedade, a communhão social, conserva-se inalterada, comquanto uma mudança continua se opere nos seus membros.

$\mathrm{O}$ consentimento commum (common consent), significa portanto, o consentimento, expresso ou tacito, de uma maioria tão esmagadora, que os que dissentem desapparecem, por assim dizer, completamente. Saber si ha, em determinado caso, consentimento commum é um facto de pratica, e não de theoria. E' um caso de observação e apreciação, como a conhecida pergunta: quantos grãos fazem um monte?

As regras legaes que passam dos antepasiados aos descendentes com força obrigatoria são leis sómente emquanto estes, por consentimento commum, as observam.

Novas regras só se tornam normas juridicas si conseguem, o consentimento commum dos que compõem a sociedade em um dado momento.

E' por isso que o costume está no começo de toda lei, escripta ou não escripta.

O que dissemos acerca da lei pura e simples, applica-se ao Direito Internacional. Comtudo a communhão sobre pela qual é dado esse consentimento, não consiste em individuos ${ }_{2}$ mas sim, em Estados. $\mathrm{Na}$ sociedade dos individuos existe uma mudança constante nos seus membros, ao passo que na sociedade dos Estados, essas mưdanças são muito mais raras. De vez em quando, na Familia das Nações, surge um membro ou desapparece outro.

Nella, os novos membros são recebidos simplesmente, por consentimento expresso ou tacito dos Estados antigos. E' pois necessario estudar o que vem a ser esse consentimento commum na Familia das Nações. 


\section{CONSENTIMENTO COMMUM NA FAMILIA DAS NAÇÕES}

As regras costumeiras do Direito Internacional ap. pareceram por consentimento commum dos Estados, que, agiram de tal forma que o seu modo de proceder incluiu e significou adhesão, ao menos tacita, a ellas. Por mais longe que estudemos a formação dos usos e a transformação delles em costumes, ellas se operam da maneira seguinte: - as relações dos Estados exigiam certas regras de proceder, usos singulares crearam-se assim, agindo os povos de um mesmo modo, quando apparecia uma occasião opportuna.

No fim da Edade-Media, desenvolvendo-se extraordinariamente o commercio, e augmentando as relações entre os povos, mais se tornou necessario o apparecimento de regras reguladoras dessas relações. Essas regras, tiradas de reflexões religiosas, moraes, historicas e racionaes, esses usos e costumes reguladores das relações entre os povos christãos da Europa, formariam mais tarde o Direito das Gentes.

Foi então que Hugo Grocio, reuniu com o seu "De Jure Belli ac.Pacis", todas as regras que então regiam as relações internacionaes, formando um corpo systematico, uma verdadeira consolidação de costumes internacionaes, e sua obra era tão perfeita e se adaptava tão bem ás necessidades do momento que se tornou a base de todo o desenvolvimento posterior do Direito dias Gentes.

Mas, sem a convicção dos governos e da opinião publica dos Estados civilizados de que essas regras deveriam ser legalmente obrigatorias, de um lado; e, sem a pressão dos interesses dos Estados, de outro, o Direito Internacional nunca se formaria. No seculo XIX, verificando-se a obscuridade e a insufficiencia dos usos e costumes, novas regras 
foram creadas por meio dos tratados. Assim as regras convencionaes crearam-se ao lado das regras costumeiras.

Novos Estados admittidos na Familia das Nações, acceitam as regras nella em vigor.

Não podem, comtudo, acceitar umas, e outras não, salvo quando, como no caso da Convenção de Genebra, são obrigatorias unicamente para algumas das partes contractantes.

Tambem um Estado não pode declarar, num dado momento, que não se submette mais a uma regra de Direito Internacional. O corpo das regras que se applicam na Familia das Nações, só pode ser alterado por consentimento commum, e não por declaração unilateral de um Estado.

Isto applica-se ás regras costumeiras e convencionaes, e violaria evidentemente o Direito Internacional o poder signatario da Declaração de Pariz de 1856, que declarasse que deixava de ser parte nella. Mas é bom observar que isso não se dá quando um dos poderes se reserva o $d i$ reito de denuncia.

\section{DIREITO INTERNO E DIREITO INTERNACIONAL}

E' radical a differença entre o Direito Interno e o Direito Internacional. Quem melhor tratou da materia foi o eminente Triepel, no seu monumental trabalho sobre o assumpto e no seu curso na Academia de Direito Internacional de Haya (1923).

Synthetizando os seus profundos e sabios ensinamentos, diremos que o Direito Interno e o Direito Internacional differem -

$1 .^{\circ}$ pelas suas fontes; $2 .^{\circ}$ pela sua propria substancia; e, 3. pelas relações que regulam. 
Pelas suas fontes, porque as fontes do Direito Interno são os costumes que surgiram nos limites territoriaes do Estado e as leis emanadas do poder legislativo do Estado e as fontes do Direito Internacional são os costumes que surgiram das relações entre os Estados e os tratados celebrados pelos membros da Familia das Nações.

Pela sua propria substancia, porque o Direito Interno é um direito do soberano sobre os individuos e o Direito Internacional não é um direito sobre os Estados mas um direito entre Estados soberanos.

Quanto ás relações reguladas, o Direito Interno regula relações entre individuos de um Estado ou entre esses individuos e o Estado e o Direito Internacional regula relações entre os Estados membros da communhão internacional.

E' porisso que affirmamos que, sendo o Direito Internacional um Direito entre os Estados, estas são as unicas pes. soas internacionaes.

Talvez a dissolução do Estado moderno ponha em seu logar grandes grupos economicos, e então teremos um Direito Internacional completamente novo

O Direito Interno e o Direito Internacional são portanto systemas juridicos distinctos.

\section{ATAQUES Á DOUTRINA DUALISTA}

Esta theoria dualista, defendida por Triepel, Oppenheim e Anzilotti foi atacada rudemente por Duguit, Krabbe e Kelsen, 3 juristas de fama mundial.

Kelsen é chefe da escola austriaca, e suas ideas são semelhantes ás dos precedentes.

Vejamos a opinião de Kelsen. 
E' impossivel affirmar que dois systemas juridicos têm validade um ao lado de outro. E' preciso, pois admittir a unidade logica do Direito Interno e do Direito Internacional - theoria monista.

A theoria dualista pretende que os dois direitos se oppõem pela differença de vontade de suas fontes. Mas é methodicamente inadmissivel derivar o Direito de uma vontade humana.

Operar do conceito da vontade, é operar de um conceito sociologico ou psychologico, e não de um conceito juridico. Introduzindo este conceito no dominio da sciencia juridica, commette-se um crime de syncretismo de methodos. O proprio Direito é vontade não é uma vontade humana que crea o Direito. A sciencia juridica não é como a Sociologia uma sciencia que se occupa do ser, mas uma sciencia do dever (Keine seinswissenschaft, sordern eine sollenswissenchaft).

E' uma sciencia normativa, refere-se só a normas. Ora a validade de uma norma depende sempre de uma outra norma de que provém.

Devemos pois imaginar todo o systema juridico como uma gigantesca pyramide cuja ponta seja uma norma suprema, chamada - norma originaria (Ursprungsnorm). Como esta norma não pode ter uma norma superior, e como a validade de uma norma deve depender de outra norma, a norma originaria é uma norma hypothetica (hypothetische Ursprungsnorm). Assim, ha unidade de systema, pois todas as normas dependem da norma originaria.

Não pode pois haver contradicção entre o Direito Internacional e o Interno. Não criticaremos essa doutrina que é escolastica pura, abstrusa e inutil.

\section{A doutrina anglo americana.}

Pensam muitos que na Inglaterra e nos Estados Unidos o Direito Internacional é parte integrante do Direito 
Nacional (Internacional law is a part of the law of land). Ora esta regra não vem nem em Halleck, Wheaton, Walker e Twiss e é condemnada por Oppenheim. A explicação da pkrase é simples. A maioria dos internacionalistas inglezes e jurisconsultos do seculo XVII e XVIII consideravam o Direito Internacional ramo do Direito Natural. Ora sendo assim a razão, a natureza, são as fontes communs de ambos os Direitos. Uma contradicção entre os dois é impossivel: dessa forna, é a natureza que decidirá a favor de um ou de outro.

Eis a quintessencia da antiga doutrina ingleza, segundo Triepel. Resulta que o Direito Internacional Publico, em toda a sua extensão (in its full extent) é uma parte do Direito Interno, e ainda a lei interna que incorpora nella as regras do Direito Internacional não crea um novo Direito, mas tem um valor declarativo unicamente; emfim, em caso de desaocordo, prefere-se o Internacional pois é o Direito Natural.

\section{Doutrina ingleza actual.}

O Direito Internacional não é por si proprio $d i$ reito inglez. Póde ser acceito ou adoptado (adopted). Par: tornar-se direito inglez é preciso a fonte do direito interno.

(Processo Keyn, Cap. do Franconia. — "Territorial Waters Jurisriction Act" (1878)

E' preciso notar ainda, com Triepel, que a doutrina tradicional é mais respeitada nos Estados Unidos (Art. 6 Const.). A Const. Allemã (art. 4).

Mas os tribunaes americanos exigem para que um tratado tenha força obrigatoria uma proclamaçáo formal do tratado pelo presidente "La loi étatique est toute puissante. Mais comme le droit international régit des rapports entre des Etats et que le droit interne régit d'autres rapports, la loi étatique ne peut pas sans transformation changer le droit international en droit interne" (Triepel).

$$
3 \text { - Faculdade de Direito. }
$$




\section{FONTES}

1 Noção: - Oppenheim, v. I p. 1.

Lafayette, v. I p. 1.

Woolsey, $\$ 1$.

Davis, p. 2.

Clovis, v. I p. 18.

Bonfils. Fauchille (1922), v. I p. 4.

2 - O Direito Internacional e a falta de coacção: Lafayette, v. I p. 23.

Nys, v. I p. 135.

Bonfils. Fauchille, v. I p. 16.

Arruda -- Concilia-se a existencia do Direito Internacional com a falta de coacção por parte do poder publico (Revista da Faculdade, v. XXI, 1913, p. 637).

3 - Fundamento: - Bonfils. Fauchille, v. I p. 6. Oppenheim, v. I p. 14.

Ponto $2 .^{\circ}$

FONTES DO DIREITO INTERNACIONAL

Já dissemos que a base do Direito Internacional é o consentimento commum dos Estados, membros da Familia das Nações.

Ora, este consentimento manifesta-se por dois modos, unicamente: - ou, o Estado dá, tacitamente, o seu consentimento, pelo costume: ou, o affirma, expressamente, 
pelos tratados. Logo, duas são as fontes do Direito das Gentes: os costumes e os tratados. - A opinião dos juristas, as decisóes dos tribunaes internacionaes, a comitas gentium (comity, convenance, countoisie internationale), não são fontes do Direito Internacional, são apenas factores que influem no seu desenvolvimento.

\section{FONTES}

Bonfils - Fauchille, v, I p. 40

Oppenheim, v. I p. 19

Lafayette, v. I p. $5(\S 3)$

\section{Ponto $3 .^{\circ}$}

\section{DOMINIO DO DIREITO INTERNACIONAL}

"Dominion of the Law of Nations is the name given to the area within Internacional Law is applicable - that. is, those States between which International Law finds validity" (Oppenheim). Ou, em vernaculo "Dominio do Direito Internacional é o nome dado á area dentro da qual o Direito das Gentes é applicavel, i. é, os Estados para os quaes é obrigatorio"

\section{DUAS DOUTRINAS}

Uns, dizem que se extende elle a toda a humanidade (Bluntschli, Fiore); outros, affirmam que se applica unicamente aos povos christãos (Martens). 


\section{FALSIDADE DESSAS DOUTRINAS}

Săo opiniões extremas e erroneas. Dizer que se extende a todos os Estados é absurdo, porque nem todos comprehendem os principios alevantados da moral christã, por falta de civilização. Affirmar ser elle applicavel unicamente aos Estados christãos, é desconhecer a sua historia: o Japão e a Turquia, p. ex., não são christãos ế fazem parte da Familia das Nações.

\section{THEORIA VERDADEIRA}

O Direito Internacional applica-se aos povos christãos, e aos que, não sendo christãos, se submettem, expressa ou tacitamente aos seus principios, baseados na Moral christã. O Japão, p. ex., entrou para a Familia das Nações, porque adoptou a civilização occidental, fundada na Moral christã, os principios do Direito da Gentes, europeu formulados de accordo com os principios da Moral de Grocio, o Pae do Direito Internacional, que era christão, que applicava ás relações internacionaes os principios da Moral christã. seguinte:

O dominio do Direito Internacional é, portanto, o

1. - Estados civilizados da Europa e da America (christãos);

2..$^{\circ}$ - Estados não christãos, que se submetteram expressa ou tacitamente aos principios do Direito Internacional, como: China, Japão, Turquia (art. 7 do Tratado de Paris, 1856).

Ha ainda Estados de posição duvidosa, como a Persia, o Sião, etc. Estes são parcialmente da Familia das Nações. Quando a sua civilização permittir entrarão ple. namente para a Familia das Nações. Comtudo, devem ser tratados com humanidade, o que nem sempre acontece. 


\section{FONTES}

Oppenheim, v. I p. 31.

Phillimore, I § 27-33.

Nys, I p. 121.

Westlake, I p. 40.

Bonfils-Fauchille, I n. ${ }^{\circ}$ 10. p. 28.

\section{Ponto 4.}

\section{CODIFICAÇÃO DO DIREITO INTERNACIONAL}

A falta de precisão das regras do Direito Internacional originou a tendencia para a sua codificação, tendencia que surgiu no seculo XVIII.

Foi Bentham o primeiro que teve a idéa, e a exprimiu, da necessidade da codificação do Direito das Gentes. A segunda tentativa foi a da convenção franceza de 1792. O projecto da Convenção franceza foi feito pelo Abbade Grégoire em 1795, e pode ser visto em Rivier (I p. 40).

Em 1861, Petruscheveg publica o seu codigo de Direito Internacional. Em 1872, Dudley-Field publica o seu celebre projecto. Mas, já em 1868, Bluntschli havia publicado o seu notavel Codigo, que teve um successo mundial, e é um dos trabalhos mais acatados sobre a materia.

Em 1889, Fiore publica o seu Direito Internacional codificado.

Vêm, depois, o trabalho de Duplessix (1906), de Internoscia (1910), que redigiu 5.657 artigos em francez, inglez e italiano, e, finalmente, Epitacio Pessoa, em 1911, publica o seu monumental trabalho - Codigo de Direito 
Internacional Publico, que veio, mais uma vez, mostrar o talento e a erudição do grande estadista brasileiro.

Alem destes trabalhos, ha outros, e ainda numerosas tentativas parciaes.

Em 1873, fundou-se uma Associação para a Reforma e a Codificação do Direito das Gentes (Associação de Direito Internacional).

Em 1880, fundou-se em S. Petersburgo uma sociedade analoga.

E é a codificação do Direito Internacional um dos escopos do Instituto de Direito Internacional, fundado em Gand em 1873.

E o mesmo fim é procurado pelo Instituto Americano de Direito Internacional, fundado em Washington em 1912.

Será possivel a codificação do Direito Internacional?

Discutem os autores sobre as vantagens e desvantagens da codificação do Direito Internacional. Essa discussão é ociosa: a tendencia hodierna é para a codificação. Vejamos, pois, si é esta possivel.

Objectam, em $1 .^{\circ}$ logar, que um legislador universal, um corpo legislativo para o mundo inteiro, implica uma organização central da humanidade, o que é uma verdadeira utopia, uma chimera. Não vejo porque: tudo tende para essa organização. Demais, não existe já o Direito Internacional Universal? Não se submettem já todos os Estados a certas regras uniformes? Deliberações de orgãos internacionaes não são respeitadas pelo mundo inteiro?

Dizem mais, que um codigo internacional implicaria: a) redacção em uma lingua unica, universalmente adoptada e traducções anthenticas; b) votação em bloco do projecto pelos Estados; c) unanimidade dos Estados. Essas condi̧̧ões, affirmam, são insuperaveis. Não concordo. Acho, que, com o tempo, com boa vontade, se conseguirá supplantar todas essas difficuldades. 


\section{AS CODIFICAÇÕES PARCIAES}

Sou favorabilissimo ás codificações parciaes do Direito Internacional. Essas, mais faceis, mais simples, serão os primeiros passos para a codificação do Direito das Gentes. Assim, devemos trabalhar indefessamente para a codificação do Direito Internacional na America, para termos o que poderemos denominar um codigo de Direito Internacional Americano.

O maior obstaculo á Codificação do Direito INTERNACIONAL

O maior e o mais formidavel obstaculo á codificação do Direito Internacional são a má fé dos governos dos Estados, a politica imperialista das grandes potencias, o machiavelismo dos grupos, das oligarchias, dos oppressores que illudem os povos, para exploral-os em proveito proprio.

0 meio mais seguro de se obter essa codificação seria luctar pela liberdade dos povos, para conseguir-se a democracia no mundo. No dia em que, com o triumpho da verdadeira Democracia, o governo for do Povo PELo povo E PaRa o Povo, o Direito Internacional será facilmente codificado el acabarão as guerras, e reinará a paz entre os homens.

Com oligarchias, com diplomacia secreta, com conchavos para opprimir povos fracos, para roubal-os, martyrizal-os, saqueal-os nada a esperar!

\section{FONTES}

Bonfils - Fauchille, v. I p. 149 (n. ${ }^{\circ}$ 1535).

Alexandre Alvarez — La Codification du Droit International.

Oppenheim, v. I p. 37. 


\section{Ponto $5 .^{\circ}$}

\section{HISTORIA DO DIREITO INTERNACIONAL}

Oppenheim, o insigne internacionalista e saudoso professor da Universidade de Cambridge, ao estudar a historia do Direito Internacional (v. I p. 48), affirma que, o Direito das Gentes, considerado como um Direito entre Estados soberanos e eguaes, baseado no consentimento commum desses Estados, é um producto da moderna civilização christã e tem apenas uns 400 annos de edadè. Essa é a theoria verdadeira.

Comtudo, as suas origens são antiquissimas, são os usos e costumes adoptados pelas nações antigas nas suas relações externas.

Parece pouco provavel que a idea de uma Familia de Nações surgisse no limitado horizonte mental do mundo antigo. Cada nação tinha seus deuses, sua lingua e sua moralidade proprias.

$\mathrm{O}$ extrangeiro era considerado como inimigo. Não havia então interesses internacionaes que ligassem com vinculo inquebrantavel os Estados em uma communhão internacional.

Entravam comtudo as nações antigas em relações, faziam a guerra, celebravam a paz, enviavam embaixadores, alliavam-se, e taes actos davam nascimento, está claro, a usos e costumes internacionaes.

E' essa a remota origem do Direito Internacional, mas esses costumes, comquanto uniformes e interessantes para o Direito das Gentes, não podiam ainda constituir o Direito Internacional tal como é concebido modernamente.

\section{OPINIÕES DIVERGENTES}

De modo contrario pensam eminentes internacionalistas. O Barão Korff, illustre internacionalista russo, no curso 
que fez em 1923 na Academia de Direito Internacional de Haya, sustenta these contraria á de Oppenheim.

Affirma que modernas investigações historicas provaram que o mundo antigo conhecia perfeitamente o sentido das relações internacionaes e applicava um systema de instituições muito desenvolvidas e firmemente estabelecidas. Appella para as leis de Hammurabi, os papyros egypcios, as taboas babylonicas e assyrias para sustentar a sua these. E tira a conclusão de que o Direito Internacional é antiquissimo, é uma consequencia de toda civilização. Attribue Korff a opinião contraria á ignorancia das civilizaçôes antigas por parte dos internacionalistas do sec. XIX.

Estas, segundo elle, só foram estudadas e ensinadas modernamente por Chybichowshy, Vinogradoff, Rostofvseff e outros.

Aponta casos para provar a antiguidade do Direito Internacional e de suas regras, sanccionadas pela religião.

Considera, p. ex., uma descoberta de Sumer, de 4 mil annos A. C., e diz que recentemente se descobriu um tratado, assignado pelo rei Entemena, regulando as fronte: nas entre o seu reino de Lagash e o reino vizinho d'Ummah. Por esse tratado foi designado um arbitro, orei Misilim de Kush. Eis ahi o arbitramento. Recorre á historia do Egypto. Ramsés II concluiu em 1820 A. C. um tratado com o rei vencido dos Hittites, Hausilitt, no qual apparece um systema perfeitamente regulado e complicado de extradição de refugiados politicos.

Ora, ninguem contesta essas affirmações, o que se contesta é a existencia entre os antigos de um Direito das Gentes, tal como é modernamente considerado.

De opinião semelhante á de Korff é Nippold. 


\section{OPINIÃO DE NIPPOLD}

No curso professado pelo grande internacionalista suisso Nippold na Academia de Direito Internacional de Haya (1924), podemos acompanhar a sua argumentação.

Affirma que o Direito Internacional deve ser estudado sem preconceito, "sub specie aeternitatis", pois é um Direito que existiu em todos os tempos e no seio de todas as civilizações. Affirma com Korff a antiquidade do Direito Internacional, e que elle era conhecido pelas antigas povoações da Africa.

E contesta, alem disto, que o Direito Internacional seja um producto da raça branca. O japonez Ukita, tambecn diz que, si dermos credito aos historiadores europeus, a historia da Humanidade seria a historia da raça branca.

Segundo o historiador Takahashi, o Japão, antes de ter relação com os europeus, já conhecia o Direito Internacional, e applicava suas regras. O mesmo se poderia dizer da China, segundo $W$ Martin (China Kodai Bankoku Koho).

Conclue Nippold, dizendo que a primeira lição a tirar do estudo da historia do Direito Internacional é uma lição de modestia. $\mathrm{O}$ patrimonio que nos legaram as antigas civilizaçóes é immenso, e não devemos desprezal-o. Si o Direito Internacional deve muito á Moral christã, diz elle, não devemos esquecer que, nos Estados buddhistas, se faz notar, quando se trata da historia da Europa, que as guerras são mais numerosas nos estados christãos. Com effeito, o Japão, durante 250 annos ei até a chegada dos extrangeiros, gozou de uma paz ininterrupta. Mas, mitiga a sua opinião dizendo que o christianismo é uma religião tão paci. fica como o buddhismo, e que se não deve culpar nenhuma destas religióes pelos erros dos homens de Estados e da grande politica ou pelas lacunas do Direito das Gentes. 


\section{CONCLUSÃO}

Korff e Nippold, segundo creio, não estão com a verdade. O Direito das Gentes é um producto da Moral Christã, como dissemos atraz, acompanhando Oppenheim. Regras isoladas regendo relações entre povos não constituem ainda o Direito Internacional, Direito que rege relações de uma "Familía de Nações" A Civilização é da raça branca" 0 - Direito Internacional, como vimos, baseia-se no consentimento da maioria esmagadora dos membros da communhão internacional, e esta adoptou para Moral a Moral Christã, que é a Moral Internacional. Si as nações civilizadas da Europa em cujo seio se formou o Direito Internacional fossem buddhistas ou mahometanos, si a essas religiões pertencesse Hugo Grocio, o fundador do Direito das Gentes, outra seria, evidentemente, a Moral internacional.

Não se póde tampouco culpar essa Moral, como confessa Nippold, pelos erros dos governos.

Como veremos mais tarde, muito tem progredido o Direito Internacional, sob o influxo da Moral Occidental. E' ociosa, segundo creio, a discussão sobre si a nossa Moral é superior ou inferior ás outras: - não discutiremos o que deveria ser, mas sim $_{\star}$ expomos somente o que é, na realidade. Diremos, de passo, que a religião christã não provo-* cou guerras, e que só por factos excepcionaes houve poucas guerras entre Estados não christãos.

O Japão, p. ex., com quem guerrearia, e para que?

A principal razão das guerras entre os Estados é a lucta de interesses, é o capitalismo, a ambição dos governos, e estas causas, segundo creio, não existiam no Japão.

Demais, logo que elle quiz entrar para a sociedade internacional, teve que se submetter aos principios da Moral Christã, i. e, da Moral Internacional. 


\section{DIVISÃO DA HISTORIA DO DIREITO INTERNA- CIONAL}

Ha, segundo Halleck, dois systemas de tratar a Historia do Direito Internacional.

$01 .^{\circ}$ consiste em dividil-a em periodos de um numero uniforme de annos, p. ex., de 50 (Hallam). $02^{\circ}$, divide a historia do Direito das Gentes em periodos estabelecidos levando em consideração acontecimentos notaveis, que marcaram epocha na Historia das relações internacionaes.

O ultimo é o mais geralmente acceito.

\section{DIVISÃO DE OPPENHEIM.}

Oppenheim, que vamos seguir passo a passo na exposição deste ponto, divide a Historia do Direito Internacional em dois periodos principaes: $10^{\circ}$ antes de Grocio; $2 .^{\circ}$ depois de Grocio.

Leva pois em consideraçã̃o o apparecimento da obra monumental de Grocio - De Jure Belli ac Pacis, em·1625, que é o ponto de partida de todo o desenvolvimento posterior do Direito das Gentes.

Cada um desses grandes periodos é subdividido por Oppenheim em varios outros, cada um delles marcado por um acontecimento notavel, synthese de uma épocha historica, com influencia no desenvolvimento posterior do Direito Internacional.

$$
\text { 1. Periodo }
$$

\section{ANTES DE GROCIO}

Como dissemos, anteriormente, na antiguidade não encontramos o Direito Internacional tal como é concebido 
modernamente, pois elle é um producto da civilização christã e tem apenas 400 annos de existencia. Mas, na antiguidade, vamos encontrar os usos e costumes que mais tarde viriam a formar o Direito Internacional.

Desde o principio dos tempos historicos o homem teve que entrar em relação com os seus semelhantes.

Divididos em tribus, cuja grande lei era o isolamento, tinham os povos primitivos que entrar fatalmente em contacto com os outros, pelo menos nas relações bellicas. Uma tribu guerreava com a outra, faziam-se tratados para celebrar a paz, eram ás vezes envilados embaixadores, cuja inviolabilidade era sanccionada pela religião. Iam, está claro, surgindo dessas relaçōes alguns usos, e nos casos identicos procediám esses povos da mesma forma, de tal sorte que esses usos se transformavam paulatinamente em costumes internacionaes.

E' essa a remota origem do Direito Internacional.

Vejamos quaes eram esses costumes entre os povos mais importantes da antiguidade.

\section{OS JUDEUS}

Tratemos em primeiro logar dos Judeus.

Apesar de serem monotheistas e de muito mais elevada moralidade e civilização que os seus vizinhos, os judeus não tiveram grande influencia no desenvolvimento do Direito Internacional. Desprezando os outros povos, o povo eleito não podia consideral-os como eguaes.

Apenas, no modo por que tratavam os extrangeiros, mostravam elles o seu elevado nivel moral.

Examinando-se alguns textos da Biblia, vê-se que tratavam os escravos extrangeiros muito melhor que todos os povos da antiguidade (Ex. XXI - 2026 e $27-$ Deut. X 19 Lev. XXIV - 22). 
Nas sulas relações bellicas faziam uma distinç̧ão interessante, assignalada por Oppenheim, entre os inimigos capitaes e os simples inimigos.

Com os seus inimigos capitaes, os Amalecitas, por exemplo, eram de uma crueldade extraordinaria. (1 Samuel - XV v. 32 Sam. XII 31).

Quando entravam em lucta com povos de que não eram mortaes inimigos, eram muito mais humanos do que os outros povos da épocha. (Deut. XX 10 14).

Ainda hodiernamente causam admiração os ideaes messianicos (Isaias, II 2 4).

As palavras propheticas de Isaias são, ainda hoje, a mais bella synthese do ideal pacifista.

\section{OS GREGOS}

As naçōes, ou melhor, as cidades gregas, independentes $\mathrm{e}$, ao mesmo tempo, interdependentes, dão-nos o $1 .^{\circ}$ exemplo de um Direito baseado no consentimento commum, regulando as relações reciprocas dos estados soberanos.

Antes da conquista macedonica, encontramos a Grecia dividida em uma porção de cidades independentes. Mas os gregos não se podiam esquecer de que tinham a cnesma lingua, a mesma raça, adoravam os mesmos deuses e tinham os mesmos ideaes de civilização. Porisso eram essas cidades independentes ou soberanas, interdependentes, formando uma communhäo internacional, uma verdadeira "Familia de Nações".

Comquanto crueis nas guerras com os barbaros, observavam entre si regras estrictas de conducta, e tinham usos internacionaes muito brandos e humanos.

Reconheceram sempre a santidade dos contractos. Ora, si observarmos que a religião era tudo na antiguidade, concluiremos que uma regra baseada em uma sanç̧ão reli- 
giosa estava muito mais garantida até do que actualmente, em tempos em que certos governos declaram os tratados trapos de papel.

Como faz notar Nippold, confundiam-se outr'ora o $D i$ reito e a Moral, mas essa confusão era menos nociva do que a invenção moderna de um Direito Internacional Amoral.

Ao lado das federações politicas gregas, como a Liga Amphyctionica, desenvolveu-se o bello instituto do arbitramento.

As praticas guerreiras eram humanas entre gregos, e não faziam estes a guerra sem prévia declaração.

Practicaram a extradição de criminosos.

E mesmo quanto aos extrangeiros, deram o exemplo de instituições tendentes a protegel-os.

Basta lembrarmos os proxenes, guardas da hospitalidade, que no sec. V occupavam o logar de consules, e os tribunaes para extrangeiros

\section{ROMA}

Passemos a Roma. Por mais longe que investiguemos as instituições romanas, encontraremos uns sacerdotes, os fetiales incumbidos de dirigir as relações de Roma com os outros povos, applicando o jus sacrale, o jus fetiale.

Devemos distinguir nas relações de Roma com os outros povos dois casos principaes;

1. - Roma tinha tratado com o povo extrangeiro;

$2 .^{\circ}$ - Roma não tinha com elle nenhum tratado.

$\mathrm{Na}$ primeira hypothese, as relações eram minuciosamente reguladas pelo Direito.

Com o correr dos tempos, foi tal a quantidade de extrangeiros em Roma que se formou para elles o jus gentium, applicado pelo proetor peregrinus. 
Os tratados de Roma com os outros povos eram:

$10^{\circ}$ - de amizade (amicitia);

$2 .^{\circ}$ - de hospitalidade (hospitium); e,

$3 .^{\circ}$ - de alliança (foedus).

As vezes nos tratados combinava-se que qualquer duvida posterior seria decidida por arbitros, os recuperatores.

Quando não havia tratado de alliança, dominava o arbitrio. A pessoa que entrasse no territorio romano éra escravizada, e assim o romano que penetrasse no territorio extrangeiro era reduzido tambem á escravidão (excepto os embaixadores). Comtudo quando voltavam novamente á patria os escravos tornavam-se livres pelo jus postliminii. A guerra era uma instituição legal, com regras precisas. As justas causas de guerra eram:

1. - a violação do dominio romano;

$2 .^{\circ}$ - a violação dos embaixadores;

$3 .^{\circ}$ - a violação dos tratados; e

$4 .^{\circ}$ - o auxilio aos inimigos de Roma.

$\mathrm{E}$ somente começavam a guerra os romanos si satisfacções não eram dadas a Roma.

A guerra era sempre crudelissima. Terminava:

$10^{\circ}$ - por tratado de paz;

$2 .^{\circ}$ - pela deditio, e

$3 .^{\circ}$ - pela occupatio.

Como veremos mais tarde, o Direito romano, a razão escripta, muito influiu. no desenvolvimento do Direito Intermacional.

\section{A EDADE MEDIA}

Variam muito os historiadores na determinação das épochas historicas. Alguns prolongam a Edade-Media até a 
renascença das letras e das artes, outros até a queda do Feudalismo. Podemos, si attendermos unicamente ao desenvolvimento intellectual, limital-a por Santo Agostinho e Boecio, de um lado e por Bacon e Descartes de outro (dominio da Escolastica). Podemos prolongal-a até a Reforma, ou ainda até quasi o fim do sec. XV, em que são factos notaveis, o desabamento do Imperio do Oriente, a conquista de Granada, a invenção da typographia, a união da Bretanha, o ultimo grande feudo, á França, o descobrimento da America e o nascimento de Luthero. Vulgarmente adopta-se a seguinte divisão da Historia: antiguidade, desde os mais remotos tempos até a queda de Roma (476); Edade-Media, de 476 a 1453 (tomada de Constantinopla); EdadeModerna, de 1453 a 1789, com a rev. franceza; e, Edade Contemporanea, de 1789 até hoje.

Como ensina Korff, os historiadores costumam dividir a Edade-Media em 2 periodos o $1 .^{\circ}$ do sec. $\mathrm{V}$ ao $\mathrm{X}$, or: "Edades-Sombrias" (Dark-ages), e o 2. do XI ao XVI.

Roma era um Imperio Mundo (World Empire) absorvendo todos os povos antigos. Difficilmente poderiam os romanos conceber um Direito destinado a regular relações de Estados'soberanos, pois estes não existiam.

A religião christã ainda veio augmentar a unidade do imperio (momentaneamente).

As coisas continuaram neste pé mesmo depois da divisão do imperio (395).

Em 476 dá-se a queda de Roma e Romulus Angustulus, o ultimo imperador é substituido pelo chefe barbaro Odoacro, começando a Edade-Media.

Os barbaros invadem o imperio. Nas Gallias surge o reino dos francos com Clodoveu em 476. Vencido Odoacro por Theodorico em 473, forma-se na. Italia o reino dos Ostrogodos. 
Em 456 o reino dos Visigodos estabelecidos na Heșpanha. Os Vandalos formaram um reino na Africa, tendo Carthago por capital: Os Saxões tomaram pé na Bretanha em 449.

Estes povos que repartiam entre si o imperio, eram barbaros, e não estavam em condições de assimilar a cultura dos vencidos.

Muitos annos foram precisos para que esses povos se erguessem a um nivel moral e intellectual, proximo do romano.

Adoptaram a religião christã e a civilização romana, mas difficilmente poderiam pretender tornar-se romanos.

Em 800 Carlos Magno restabeleceu novamente a unidade, e foi coroado imperador romano pelo Papa Leão III.

O imperio franco durou pouco, pois em 845 , pelo tratado de Verdun, se fraccionou em tres partes, que foram o embryão de onde mais tarde se formariam as diversas nações europeas.

\section{OS SECULOS XV E XVI}

Nos seculos $X V$ e $X V I$, o Direito das Gentes torna-se indispensavel na Europa. Nesse pegueno continente, surgiu uma multidão de: Estados independentes. Com o desenvolvimento extraordinario do commercio nessa epocha, estabeleceram-se as relações entre os povos. Era indispensavel que um direito apparecesse para regular essas relações.

Factores que influiram no desenvolvimento do Direito Internacional nessa épocha.

Ensina Oppenheim que nessa épocha sete factos influiram grandemente no desenvolvimento do Direito Internacional. Veijamos quaes foram.

1. - Os civilistas e canonistas. O renascimento do estudo do Direito Romano, com Irnerio, os glosadores e 
postglosadores, que reputavam este Direito, o Direito por excellencia, a ratio scripta, não poderia deixar de influir grandemente na formação de um Direito que se creava nessa épocha. E' de notar que os civilistas consideravam o Direito Romano o Direito do mundo civilizado, e trataram de varias materias internacionaes, commentando o Corpus Juris.

Os canonistas, por sua vez, trataram da guerra, procurando abrandal.a, tornal-a mais humana.

$2^{\circ}$ - As collecções de leis maritimas. No sec. VIII, começou o commercio maritimo a desenvolver-se, e appareceram costumes maritimos, reunidos em corpos de leis. As mais notaveis dessas leis maritimas foram: o Consolato del mare (sec. XIV) de Barcelona; as leis de Oleron (sec. XIII); a lei Rhodia (sec. VIII ou IX); as leis de Wisby (sec. XIV), da ilha de Gothland na Suecia.

O augmento do commercio foi causa do apparecimento de controversias sobre a liberdade dos mares.

3. - As ligas de cidades.

4.․ - As embaixadas permanentes.

$5 .^{\circ}$ - Os exercitos permanentes.

6. ${ }^{\circ}$ - A Renascença e a Reforma.

7 - Os projectos de paz perpetua.

2. Periodo

\section{O DIREITO INTERNACIONAL DEPOIS DE GROCIO}

\section{O tempo de Grocio}

O sec. XVII apresenta-nos a Europa dividida em umi multidão de pequenos Estados independentes. Ora, com o augmento extraordinario do commercio, cresceram espan- 


\section{$-52-$}

tosamente as relações entre os povos:-era indispensavel o apparecimento de regras para reger essas relações.

Foi então que Hugo Grocio reuniu em um corpo unico, todos os usos e costumes internacionaes de sua épocha, formando um verdadeiro Codigo ou consolidação - De Jure Belli ac Pacis. Essa obra correspondida de tal forma ás necessidades do momento que foi considerada verdadeira lei.

E' porisso que Grocio é denominado "Pae do Direito Internacional"

\section{Precursores de Grocio}

Grocio teve precursores. Legnano, Belli, Victoria, Ayala, Suarez e Gentili (1552-1608), italiano, professor em Oxford.

O livro de Gentili, De Jure Belli, foi mesmo o modelo de Grocio, mas, comquanto Grocio muito deva a Gentili foi o maior dos dois, e foi com justiça denominado "Pae do Direito Internacional"

\section{Hugo Grocio}

O grande jct. hollandez nasceu em Delft em 1583. Desde a mais tenra edade mostrou grande talento e amor ao estudo, sendo considerado um menino prodigio. Começou a estudar Direito em Leyden aos 11 annos e aos 15 era Doutor em Leis por Orleans.

Em 1618 foi condemnado á prisão perpétua. Em 1621 fugiu.

Em 1634 entrou para o serviço da Suecia, tornando-se Ministro Sueco em Pariz.

Morreu em 1645 em Rostock.

Em 1609 escreveu o. "Mare Liberum" 
Em 1625, publicou o "De Jure Belli"

Este livro immortal, considerado como o mais importante depois da Biblia, é o fundamento de todo o desenvolvimento posterior do Direito das Gentes.

A sua intenção foi, a principio, escrever um livro sobre a guerra, impressionado com as crueldades practicadas nas luctas do seu tempo (vide Revista da Faculdade - Submarinos de guerra - These do Doutor Braz de S. Arruda). As suas investigações o levaram muito longe e publicou um verdadeiro tratado de Direito Internacional.

\section{Doutrina de Grocio}

Grocio acreditava no Direito Natural, e dividia o Direito das Gentes em voluntario (Jus voluntarium), originado dos costumes internacionaes; e Jus naturale ou Direito Natural applicado aos Estados.

\section{Zouche}

Este, que póde ser considerado um fundador menor do Direito Internacional sustentava, comquanto não negasse a existencia do Direito Internacional Natural, que o Direito Internacional costumeiro, era mais importante. $\mathrm{O}$ seu trabalho, escripto em 1650 pode ser considerado o $1 .^{\circ}$ manual positivo do Direito Internacional.

Foi elle tambem o $1 .^{\circ}$ a usar das expressões - Jus in. ter Gentes. Grocio denominava a sua sciencia Jus Gentium e devido á sua influencia originou-se a expressão - Direito das Gentes. Mais tarde Bentham adoptaria a expressão $D i$ reito Internacional (International Law). 


\section{Escolas de Direito Internacional}

Da influencia contraria de Grocio dando preferencia ao Direito Natural sobre o positivo, e de Zouche, preferindo o positivo ao natural, originaram-se as tres escolas de Direito Internacional: - naturalista, positiva e grociana.

\section{Os NATURALISTAS}

Os naturalistas negam a existencia de um Direito Internacional originado dos costumes e dos tratados.

Consideram o Direito Internacional um ramo do $\mathrm{Di}$ reito Natural, o Direito Natural applicado ás nações. Os principaes são: Pufendorf, Thomasius, Hutcheson, Rutherford, Barbeyrac e Burlamaqui.

\section{Os POSITIVISTAS}

Os positivistas sustentam que o Direito Internacional positivo, originado dos usos e costumes e dos tratados, modos por que se manifesta o consentimento commum dos Estados que compõem a familia das nações é muito mais importante do que o Direito Internacional Natural. Alguns positivistas negam mesmo a existencia do Direito Natural

Rachel e Textor escreveram no sec. XVII, quando a escola começou a ter importancia. Temos no sec. XVIII, Bynkershoeck, Moser e Martens. De todos elles o mais positivo é Bynkershoeck, que baseia o Direito Internacional no consentimento commum.

Os outros não negam a existencia do Direito Internacional Natural, comquanto lhe attribuam importancia secundaria. 


\section{Os GROCIANOS}

Os grocianos dão importancia egual ao Direito Internacional Natural e ao Positivo. Os principaes são Wolff, Vattel, e a maioria dos escriptores francezes.

\section{OBRAS PRINCIPAES DOS POSITIVISTAS}

A $1 .^{a}$ obra verdadeiramente positiva de Direito Inter. nacional foi a de Hartmann (1874).

A 2. ${ }^{\mathrm{a}}$ a de Hall (1870). Depois a de Oppenheim, o mais insigne representante da nossa escola.

Liszt, Ullmann e Stockton podem ser considerados positivistas.

Depois do apparecimento do De Jure Belli

Estudados os factores que influiram no espirito de Grocio, estudemos a seguinte épocha do Direito Internacional, depois do apparecimento de sua obra, em 1625.

No tempo de Grocio, achava-se a Europa dividida em um grande numero de Estados, com continuas relações commerciaes.

Foi indispensavel o apparecimento de regras de acção que regulassem as relaçôes reciprocas desses povos. Foi para regular as relações internacionaes dos Estados, que appareceu o Direito das Gentes. Grocio, como christão, inspirou-se, quando fundou o Direito Internacional, na Moral Christã, e porisso é essa ainda a Moral da humanidade culta, a Moral do Direito das Gentes. E' considerado justo em Direito Internacional o que é justo em face dos principios christãos. A violação de principios christãos é a violação de principios do Direito Internacional.

A historia do Direito Internacional depois de Grocio, pode dividir-se nos seguintes periodos: 1648 172], 1721 
1789, 1789-1815, 1815 1856, 1856-1874, 1874-1899, 18991914,1914 1918, 1918 até hoje.

1648 1721. - Começa este periodo com a Paz de Westphalia. As reuniões der Munster (catholicos) e Osnaburgo (protestantes), são os primeiros exemplos de congressos reunidos para resolver questões internacionaes pelo consentimento commum dos povos.

Resultados do Congresso:

1. - A Suissa torna-se independente.

$2 .^{\circ}$ - Os 332 estados do Imperio Germanico formam uma confederação, tendo o imperador por chefe.

$3 .^{\circ}$ - Desapparece o principio da unidade do mundo.

$4 .^{\circ}$ - Surge o principio do equilibrio europeu.

5. - Os Estados protestantes e catholicos são tratados no mesmo pé de igualdade. A politica de conquista de Luiz XIV tem como consequencia numerosas guerras.

Neste periodo o "Rei Sol" viola o Direito Internacional a todo momento, mas sempre acha um meio de se desculpar, e nunca confessa a violação. Tratados importantes: $1 .^{\circ}-\mathrm{Paz}$ dos Pyreneus (1659); - 2..$^{\circ} \mathrm{Paz}$ de Aix-la-Chapelle (1668);-3. ${ }^{\circ}-\mathrm{Paz}$ de Nymegue - $4 .^{\circ}$ — Paz de Ryswick (1697); - 5. - Paz de Utrecht (1713) e as de Rastad e Baden, de 1714, terminando a guerra dia successão da Hespanha. Alem destes tratados celebrados em virtude de guerras com a França outros foram concluidos. Entre elles: $1 .^{\circ}$ - Paz de Roeskild $(1658) ;-2 .^{\circ}-$ Oliva (1660); - 3. Copenhague $(1660) ;-4 .^{\circ}$ - Kardis (1661); - 5. - Breda (1667); - 6. - - Carlowitz; $7^{\circ}$ - Nystaed (1721), entre a Russia e a Suecia (a Russia, entria para a familia das nações).

Depois de 1721 ha grande progresso no Direito Internacional, principalmente em materia de visita, bloqueio 
e liberdade dos mares. A doutrina do equilibrio europeu é solemnemente proclamada (Paz de Utrecht).

17211789 - Distingue-se pela rivalidade entre a Austria e a Prussia. Paz de Aix-la-Chapelle (1748). Paz de Hubertsburgo. Paz de Versailles (1783). Partilha da Polonia (1772, 1793 e 1795). A Prussia torna-se grande potencia. 1." neutralidade armada. A America do Norte torna-se grande potencia, e entra para familia das nações, onde, representa papel salientissimo.

17891815 - Revolução franceza. Napoleão I. Bloqueio continental.

Congresso de Vienna (1814 e 1815). O Congresso de Vienna teve que reorganizar a Europa, e discutiu tambem questộes internacionaes.

18151856 - Santa Alliança. Doutrina de Monroe.

A Grecia e a Belgica. Napoleão III adopta o principio das nacionalidades, e torna-se imperador da França.

Guerra de Crimea., Declaração de Paris (16 de Abril de 1856).

$18561874-\mathrm{O}$ principio das nacionalidades continua triumphante. Unifica-se a Allemanha. A Austria torna-se monarchia dual, e ha a Unificação da Italia (V Marcel Moye). - Estados Unidos. Leis de guerra (1863) Convenção de Genebra (1864). Declaração de S. Petersburgo (1868). Conferencia de Londres (1871). Conferencia de Bruxellas (1874). 1874 1899 - Principio das nacionalidades iriumphante.

1874 1899 - - Guerra em 1894 entre a Chimi e o Japão. Paz de Shimonoseki.

Guerra dos Estados Unidos com a Hespanha (1898). Independencia de Cuba (Tratado de Paz de Paris). 
Conferencia de Benlim sobre o Congo (1884 5), Conferencia de Haya de 1899. China.

1899 1914 - Guerra sul-africana. Intervenção na

Guerra russo-japoneza.

Rivalidades entre a França e a Allemanha em Marrocos -..Guerra italo-turca. (1911).

Intervenção americana no Mexico (1914).

Segunda Conferencia de Haya (1904).

Conferencia Naval de Londres (1908). Arbitramento.

19141918 - Em consequencia do assassinato do $\mathrm{Ar}$ chiduque Austriaco Francisco Fernando em Serajevo (28 Junho 1914) rompe a grande guerra.

Em 28 Julho 1914 a Austria declara guerra á Servia. Em 4 de Agosto a Allemanha viola o territorio belga, e a Inglaterra declara guerra á Allemanha.

Em 30 Outubro 1914 a Turquia une-se á Austria e á Allemanha, e a Bulgaria faz o mesmo em 11 Outubro 1915.

Combatem 26. alliados contra a Allemanha. Os principaes são: Grã Bretanha, França, Russia, Belgica, Servia, e, mais tarde, Estados Unidos e Italia.

A Allemanha começa a guerra, violando o territorio da Belgica, atacando de frente todos os principios do Direito das Gentes, universalmente acceitos. Esperavam os barbaros que a historia justificasse os seus crimes. Mas não, a humanidade se convenceria mais uma vez da lição da historia do Direito Internacional: - todo o povo que violar os principios do Direito Internacional será fatalmente esmagado e vencido, obrigado a submetter-se á vontade dos Estados membros da Familia das Nações, aos principios do Direito das Gentes, á Moral Internacional. 
Em 1915, a Allemanha começa à guerra submarina. Em 7 de Maio de 1915 ha o torpedeamento do Lusitania, um dos crimes mais nefandos da historia (vide Conferencias Patrioticas, na Rev. da Faculdade de 1920).

Em 1916 e 1917 toma vulto, e torna-se cada vez mais cruel a guerra submarina. A Allemanha procura espalhar o terror sobre a terra (V. Conferencia - O Grime e a loucura da Alliemanha, na Revista da Faculdade).

Em 30 de Fevereiro, a America do Norte rompe as relações com a Allemanha, e em 6 de Abril declara-lhe guerra.

Em Março de 1917, a revolução russa impressiona os espiritos. Em 3 de Março de 1918, finalmente, o governo bolcheviki assigna o tratado de Brest Litowsk. A Russia abandonava a causa da civilização, justificando mais uma vez a phrase: traidor como um russo!

Povo miseravel de vis escravos, barbaros orientaes que nunca chegaram a assimilar a civilização europea, os russos iriam pôr em perigo a felicidade mundial. Mas a fé de latinos e anglosaxóes triumpharia, assim mesmo, do militarismo prussiano. Em 1918, a Allemanha faz o seu supremo esforço. Em Outubro, principiam as negociações para a paz, que tem como resultado o armisticio de 11 de Novembro. Já haviam abandonado a lucta os seus alliados: a Bulgaria com o armisticio de 29 de Setembro de 1918, a Turquia com o de 30 de Outubro e a Austria com o de 3 de Novembro.

Estava assim terminada a grande guerra: a Allemanha, violadora do Direito Internacional, vencida, teria que submetter-se aos seus principios.

Começa então uma nova épocha, iniciada em 1918.

1918 - - A Confercncia da Paz abre-se em 18 de Janeiro de 1919. Em Maio, o tratado de paz com a Allemanha é apresentado aos seus plenipotenciarios. Depois 
de algumas modificações é assignado em Versailles (28 de Junho de 1919).

O tratado de paz com a Austria é assignado em St. Germain (10 de Setembro de 1919).

As consequencias desses tratados são bem conhecidas, e serão estudadas por nós, pormenorizadamente, mais tarde.

\section{SETE LIÇÕES DA HISTORIA DO DIREITO INTERNACIONAL}

Temos estudado assim resumidamente a historia do Direito Internacional atravez dos tempos, desde a antiguidade até hoje.

De nada serviria comtudo o estudo dessa historia, si della não tirassemos alguma moralidade, alguma lição para o futuro.

Oppenheim, o saudoso professor de Cambridge tira da historia do Direito Internacional sete lições. Vejamos pois quaes são essas sete lições da historia do Direito Internacional.

$1 .^{a}$ - Só é possivel a existencia do Direito Internacional existindo um equilibrio uma balança dos poderes entre os membros da Familia das Nações.

$2 .^{a}$ - O Direito Internacional só progredirá, quando a intervienção for sómente no interesse dos Estados. Essa condemnação das intervenções para defender interesses dynasticos ou religiosos é justa.

3. ${ }^{\mathrm{a}}$ - E' necessaria a victoria da DEMOCRACIA sobre a autocracia.

$4 .^{\mathrm{n}}$ - $\mathrm{O}$ PRINCIPIO DAS NACIONALIDADES tem tanta força que é infructifero querer impedir a sua victoria."

5. ${ }^{2}$ — Todo progresso em Direito Internacional só é possivel em tempo opportuno.

$6 .^{a}$ - E' preciso que a Escola JURIDICa de Direito Internacional prevaleça sobre a Diplomatica. Si a escola juri- 
dica quer que o Direito Internacional se desenvolva nos moldes do Direito Interno dos Estados (Municipal Law), deseja uma codificação das regras do Direito Internacional, e pugna pela creação de Tribunaes internacionaes, a es. cola diplomatica prefere que o Direito Internacional continue como um corpo elastico de regras, e sustenta que a solução diplomatica das questões internacionaes e o arbitramento são sufficientes e preferiveis aos tribunaes inter. nacionaes com juizes permanentes.

7. ${ }^{\mathrm{a}}$ - $\mathbf{O}$ desenvolvimento do Direito Internacional depende da moralidade publica e dos INTERESSES ECONOMICos. Pode-se affirmar que o Direito Internacional, assim como o Direito Interno é um producto de FACTORES ECONOMICos, e, ao mesmo tempo a base para um desenvolvimento favoravel de interesses moraes e economicos. (V Revista da Faculdade. $\mathrm{O}$ interesse economico, vol. XXI)

Sendo isto um facto indisputavel, um progresso incommensuravel está reservado ao Direito Internacional pois tem factores moraes e economicos eternos trabalhando indefessamentè a seu favor.

\section{FONTES:}

Bonfils-Fauchille - 1..$^{\circ}$ p. 67.

Oppenheim, $1 .^{\circ}$ p. 48.

Davis, Int. Law, p. 4.

Taylor, $\oint \oint 6-29$.

Ullmann, $\oint \oint 12-24$.

Lawrence, $\oint \oint$ 13-22.

Halleck, I p. 1-11.

Nys, I p. 1-22 e Les Origines $d u$ D. Int.

Calvo, I p. 1-32. 
Ponto 6.

\section{Pessoas internacionaes - Reconhecimento e mudança em sua condição.}

I - Pessoas internacionaes.

Direito Internacional, como já vimos, é o corpo de regras costumeiras e convencionaes, que, por consentimento commum, são consideradas legalmente obrigatorias pelos Estados civilizados em suas relações reciprocas. (Oppenheim, Int. Law, I pag. 3. Hall, Int. Law, pag. I — Davis, pag. 1).

Se o Direito Internacional funda-se no consentimento commum dos Estados civilizados, esses é que são pessoas internacionaes, como ensina Oppenheim.

São pessoas de Direito Internacional unicamente os. Estados soberanos, os unicos sujeitos do Direito das Gentes (Davis, 29. - Oppenheim, 107).

Ḿas se todos os autores reconhecem que o Estado é a pessoa internacional por excellencia (Epitacio, Cod. artigo segundo - Hall, Int. Law, pag. 17 - Bonfils, pag. 77), comtudo discutem se é a unica pessoa internacional.

\section{OS SOBERANOS E AGENTES DIPLOMATICOS}

Heffter ( $\$ 48$ e seguintes) sustenta que os soberanos e agentes diplomaticos são pessoas internacionaes.

Contra Heffter estão Oppenheim, v. I, pags. 108, 127, etc., Despagnet 87, e outros. Ao estudarmos mais tarde a posição dos chefes de Estado provaremos que elles são objecto do Direito Internacional, e não são senão representantes dos seus Estados.

Tambem erra lamentavelmente Fiore (Cod., 51-61-64), seguido por alguns (Cruchaga, etc.), dando aos individuos caracter de pessoas internacionaes. O Direito Internacional 
regula as relações internacionaes dos individuos em muitos casos, mas estes são tratados no caracter de objecto do Direito das Gentes. Regular, o Estado a extradiçẫo, a naturalização, etc., não significa reconhecer o individuo como pessoa internacional. Os Estados tratam tambem de regular as communicações telegraphicas entre si, e os te. legraphos não são pessoas internacionaes.

Comtudo, alem de Cruchaga, o eminente Westlake sustenta a these absurda de Fiore (Chapters, pag. 2).

Não podemos considerar tampouco pessoas internacionaes as corporações (Lawrence), nem os povos nomades, ou depois da perda do territorio.

\section{OS CHEFES DE RELIGIŌES}

Lord Phillimore, filho illustre do eminente Sir Robert Phillimore, sustenta (curso na Academia de Direito Internacional de Haya) que os Estados não são as unicas pessoas do Direito Internacional, e accrescenta: "Existem, com effeito, instituições, podieres de um outro genero, os grandes chefes das Igrejas ou das religiões organizadas, como Sua Santidade o Papa, Sua Beatitude o Patriarcha de Constantinopla, e para os Mahometanos, o Khalifa. Ós governos que têm entre os seus subditos um grande numero de Catholicos romanos, christãos, orthodoxos ou mahometanos devem entrar em relação com o poder religioso"

Refere-se ainda Lord Phillimore ás companhias ou associações, para exploração de paizes não europeus, e que comquanto submettidas ao soberano do paiz, ao qual deviam sua incorporação, procediam para com outros paizes como estados semi-soberanos.

Parece-me que não tem razão o eminente Lord, somente podemos considerar pessoa internacional o Papa, e assim 
mesmo pessoa sui-generis. O Patriarcha de Constantinopla e o Khalifa, representando idéas moraes, são tratados com a devida consideração pelos Estados, mas não têm nenhuma posição internacional.

Como veremos, dentro em pouco, o caso das associações é simples e facilmente se resolve, pois sendo a soberania divisivel existem Estados semi-soberanos.

Por conseguinte só os Estados soberanos, corrio disse, são pessoas de Direito Internacional.

\section{Estados SEMI-SObERANOS}

Mas alguns reconhecem a existencia de povos semi-soberanos. Estes, como ensina Oppenheim, são pessoas imperfeitas de Direito Internacional. Estudaremos, dentro em breve a posição internacional destes Estados.

\section{PESSOAS APPARENTES DE DIREITO INTERNA- CIONAL}

Com o mesmo eminente Professor inglez, observarei que ao lado dos Estados soberanos, que são as pessoas reaes do Direito Internacional, existem as confederações, a Sánta Sé e os insurgentes, que são pessoas apparentes de Direito Internacional. - Estudaremos o assumpto em pontos seguintes detalhadamente.

\section{O ESTADO E SEUS CARACTERISTICOS}

A expressão Estado - tem sido definida, como muito bem diz Moore (Digest, $\S 3 .^{\circ}$ ), del varios modos. Mas, de accordo com EPITACIO PESSOA, no seu Codigo de Direito Internacional Publico, synthese de tudo quanto ha de mais completo na nossa sciencia, podemos dizer que o 
Estado, para os fins do Direito Internacional é ". u ums reunião permanente de individuos que habitem um territorio determinado, e obedeçam a um mesmo governo, incumbido de administração da justiça e da manutenção da ordem" (artigo $10^{\circ}$ ). Concordam com este conceito $O p$ penheim, Int. Law, $1 .^{\circ}$ pag. 108; Davis, pag. 31 ; Cruchaga, 69; Merignhac, $1 .^{\circ} 115$; Despagnet, 88; Pomeroy, $\$ \$ 47$

56; Woolsey, $\S 36 ;$ Bluntschli, $\S \S 17-27$; Martens, 16; Wildman, pag. 36; Phillimore, $\S \oint 63-65$, Creasy, $93-99$ e 112-118; Bonfils, 81; Bevilaqua, 1. pag. 37, etc.

O Estado tem como elementos caracteristicos:

1. ${ }^{\circ}$ - Povo, - aggregado de individuos, que podem pertencer a raças differentes, religióes diversàs, etc.

$2 .^{\circ}$ - Territorio, - extensão do globo sobre que se fixou o povo, podendo ser grande ou pequena.

3. - Governo, -- uma ou mais pessoas representantes do povo, fazendo e applicando leis, pois as communhỗes anarchicas não constituem Estados.

4. - Governo Soberano, - ou supremo poder dentro da communhão social e independencia exterior.

Estes são os caracteristicos do Estado.

\section{SOBERANIA}

Já vimos que um dos elementos do Estado é o governo soberano.

Mas que é soberania?

Só têm personalidade internacional os Estados soberranos?

São perguntas que acodem logo ao espirito e para as quaes a solução não é facil. Os autores divergem muito sobre a materia.

Observando os Estados existentes, vemos logo ao lado dos Estados plentamente soberanos, outros, só parcialmente 
soberanos, semi-soberanos. Como elles evidentemente não possuem a soberania senão parcialmente, para certos fins, pergunta-se: são os Estados semi-soberanos pessoas de Direito Internacional? .. nos? ..

Ainda mais, pergunta-se: Ha Estados semi-sobera-

Uns sustentam que sendo a soberania indivisivel, elles não possuem senão uma soberania reflexa, entram em relação com os outros povos, porque assim o quer, porque assim o permitte o Estado plenamente soberano.

Para estes, não ha na realidade Estados semi-soberanos. Estes são parte do territorio do Estado soberano, e têm uma soberania indirecta por concessão do Estado soberano (Halleck, Int. Law, pp. 43 e 47).

Outros, ao contrario, sustentam que a soberania é dívisivel e portanto ha Estados semi-soberanos, tendo una parte da soberania, constituindo pessoas de Direito Internacional, comquanto imperfeitamente (Oppenheim, Int. Law, pag. 109).

Devo advertir ainda que numerosos autores, considerados notaveis e profundos, proclamam a indivisibilidade da soberania, e reconhecem a existencia de Estados semi-soberanos!

\section{OPPENHEIM E OS ESTADOS SEMI-SOBERANOS}

A melhor opinião sobre a materia parece-me a de $O p$ penheim, o preclaro Mestre da Universidade de Cambridge (Int. Law, 1. ${ }^{\circ}$ pag. 109).

Diz elle que não ha duvida em que os Estados semisoberanos não podem ser sujeitos perfeitos e normaes do Direito Internacional.

Mạs, é erro dizer que elles não têm uma certa posição e não são ao menos parcialmente membros da Familia 
das Nações. Si nós observarmos attentamente o que se passa na realidade, veremos que elles exercitam certos direitos, a têm certas obrigações das pessoas internacionaes. Enviam, e recebem agentes diplomaticos, ao menos consules. Celebram tratados, principalmente commerciaes. Os seus monarchas possuem privilegios que, de accordo com o $\mathrm{Di}$ reito Internacional e as leis internas dos Estados, devem ser concedidos aos monarchas extrangeiros.

Basta isso para provar que os Estados semi-soberanos são de certo modo pessoas internacionaes. Esta soberania imperfeita é uma anomalia; mas tambem a existencia de Estados sem plena soberania é outra anomalia.

A Historia ensina que elles não têm duração, porque, ou se tornam independentes, ou desapparecem completamente, e tornam-se simples provincias de outro Estado.

Os Estados semi-soberanos, continua Oppenheim, constituem tal anormalidade que se não pode dar uma regra fixa sobre elles e sobre a sua posição na Familia das Nações, porque tudo depende do caso especial. São, pouco mais ou menos, dominados pelo Estado de que dependem.

O seu caracter comtudo de pessoas internacionaes apparece claramente, quando são comparados com os Estados coloniaes, como o Dominio do Canadá e a Common wealth da Australia.

Os Estados coloniaes não têm nenhuma posição internacional.

Para o Direito Internacional, nada mais são do que partes da metropole, comquanto gozem mesmo de perfeito self-government, podendo ser chamados, de certo modo, Estados.

O factor decisivo é que o seu governador é pago pela metropole e o seu parlamento pode ser abolido e o da metropole legislar directamente para a sua colonia. 
Esta distincção de Estados soberanos e semi-soberanos repousa na divisibilidade da soberania.

Mas, que é soberania?

E' a soberania divisivel? sivel.

Vamos responder o mais resumida e claramente pos-

\section{Definição de Soberania}

Ha dois modos principaes de definir a soberania.

Orlando (Pr. de Diritto Costituzionale, pag. 53) dá estes dois modos, que, por vias diffferentes, chegam á mesma conclusão.

A doutrina dominante define a soberania como a fonte de todos os poderes publicos, como um direito supremo em que todos os outros direitos acham a sua synthese ve explicação.

Assim Gonzalez, Man. de la Const. Argentina, (pag. 81): " .designa o poder supremo para reger a communhão"

Mas, observa agudissimamente Orlando, esta theoria tem o defeito de definir o conceito não em si mesmo mas em seus effeitos. Podemos saber que a soberania é a fonte de todos os poderes e não sạbermos o que seja a soberania, o que seja este direito supremo do qual todos os outros se derivam, esta fonte de todos os direitos, de todos os poderes.

O segundo modo de definir a soberania, é o que podemos denominar scientifico ou germanico.

Gerber, definiu a soberania ".. o poder de querer, em um organismo moral concebido como pessoa" Esta foi a primeira definição scientifica de soberania.

Mas, a definição de Gerber ainda não é perfeita.

Foi mais tarde completada por Orlando A. Ruiz, etc. 
0 conceito de Gerber, corresponde ao momento da affirmação da personalidade do Estado. Ora, como observa Orlando, este não é ainda o momento da soberania.

Este é o lado psychologico, a simples affirmação da personalidade do Estado.

O homem na esphera individual affirma a sua personalidade, e dahi nasce a sua capacidade. Todos os direitos subjectivos são consequencia desta capacidade juridica.

0 mesmo se dá com o Estado.

Affirma-se como pessoa, e a esta affirmação corresponde a sua capacidade jurìdica, é este o momento da soberania. (Orlando, cit. pag. 54).

Podemos, pois, definir a soberania, com $V$ E. Orlan$d o:$ :. l'affermarsi dello statto come giuridica persona, e quindi la fonte della sua generale capacità di diritto" Vê-se por esta definição que os dois modos de definir a soberania chegam ao mesmo resultado por caminhos differentes. (Conf. Arangio Ruiz, Dir. Cost., pag. 17). A Soberania é do Estado.

Quando o Estado affirma a sua personalidade perante os individuos, tem soberania interna, quando se affirma perante os outros Estados, tem a soberania externa. A soberania como a capacidade não é illimitada. A soberania repousa na consciencia popular, e é um facto que se desenvolve historicamente pelo consentimento commum fundamento do Direito.

OPINIÃO IMPORTANTISSIMA DE NipPOLD.

O grande Nippold, um dos mais celebres internacionalistas do munido, no curso professado em 1924 na Academia de Direito Internacional de Haya, desenvolve as mesmas ideas sobre soberania e pessoas internacionaes que eu vinha ensinando na Faculdade ha muitos annos, e 
que tão grande espanto causavam na nossa velha e tradicional Academia.

Affirma o grande Mestre: "Au sens du Droit International la souveraineté ne représente effectivement rien autre chose que l'affirmation dans les relations interna tionales de la personalité libre de l'E'tat, la reconnaissance des E'tats comme sujets du Droit internacional. Nous n'avons donc pas à faire avec un droit ou un principe special, mais tout simplemente avec l'E'tat en tant que personne"

\section{A soberania é Límitada e divisivel}

Ora, a soberania é portanto evidentemente limitada pelos direitos individuaes, não diremos fundamentaes, que repousam tambem na consciencia popular, desenvolveram-se, historicamente, pela conveniencia, pela utilidade, pelo consentimento commum dos membros da communhão social. Si isto se passa na esphera individual, o mesmo acontece na internacional. A soberania externa é claramente limitada pela soberania dos outros Estados, como na esphera individual a capacidade de um individuo é limitada pela capacidade dos outros. Isto é que os jurisconsultos de todos os tempos não viram, ou não quizeram ver, por teimosia, ou não puderam ver, por falta de illuminação. Só hoje é que a Liga das Nações veio abrir-lhes um pouco os olhos obscurecidos pelo fumo dos preconceitos. Só hoje começam a dizer que é preciso mudar o conceito da soberania, adaptando-o ás necessidades do momento; $i$. $e$, reconhecem que a velha historia da soberania, indivisivel e illimitada, é uma roupa usada, imprestavel e incompativel com a cultura moderna.

Isto vem provar que os jurisconsultos metaphysicos, os defensores do Direito Natural, os escolasticos, os discutidores de theorias cerebrinas, deviam ir para manicomios, para 
ão continuarem a confundir coisas simples, e tornar obsuras coisas claras.

\section{VARLAÇŌES DA DOUTRINA}

Em materia de soberania então, a influencia dos jurisconsultos ignorantes foi desastrosa. Nunca houve matéria tão discutida, e podemos dizer com Oppenheim que: "It is an indisputable fact that this conception, from the moment when it was introduced into polictical science until the present day; never had, a meaning which was universally. aggreed upon"

Este termo foi usado em varias accepções, e o seu conceito variou muitissimo atravez dos tempos, o que se poderá ver lendo Merriam, History: of Soveringty since Rousseau, ou o magnifico resumo de Oppenheim, Int. Law, pag. 110 e seguintes, do conceito de soberania nas differentes épochas.

Não discutiremos a theoria da divisibilidade ou indivisibilidade da soberania. Não atacaremos nem defenderemos Waitz ou Calhoun, não citaremos o Federalista de Hamilton, Madison e Jay, apenas observaremos os factos.

Logicos ou não, irracionaes ou não, certos ou não, vejamos os factos.

Os factos não são feitos pelas theorias, mas estas é que nascem dos factos. Os factos não devem submetter-se ás theorias, mas estas é que devem submetter-se aos factos.

Com Oppenheim, observemos o que se passa na realidade. Como vimos ha povos semi-independentes, logo a soberania é divisivel.

Esta minha opinião ainda é fortificada pela Liga das Nações, que vem provar mais uma vez que a soberania é divisivel e limitada. Foi o que levou os grandes juriscon- 
sultos patrios a dizerem que a Liga das Nações exigia um novo conceito da soberania ..

Quando estudarmos a Liga das Nações, voltaremos novamente ao assumpto.

\section{A SANTA SÉ}

Primitivamente o Papa era monarcha de um dos Estados da familia das Nações.

Não ha duvida que, em tal caso, os Estados do Papa eram uma pessoa internacional. Como observam os internacionalistas, havia comtudo uma anormalidade. Esses privilegios eram concedidos ao Papa, antes como chefe da Egreja que como monarcha. Mas estes privilegios eram tambem só pertinentes ao ceremonial. Em 1870, os Estados do Papa foram annexados pela Italia. O Papa chefe da Christandade não podia comtudo tornar-se um subdito italiano como qualquer outro. Foi a origem da "Lei de Garantias" E' caro, como ensina Westlake, que, não sendo mais o Papa monarcha de um Estado, não existindo este mais, a Santa Sé não pode ser mais uma pessoa internacional.

Mas, de outro lado, elle envia, e recebe embaixadores, que gozam de todos os privilegios, o Papa é tratado como monarcha.

Por costume, pelo tacito consentimento, diz Oppenheim, tem a Santa Sé uma quasi posição internacional.

Completando a opinião de Oppenheim, podemos dizer que a Santa Sé foi outr'ora uma pessoa internacional, a sua personalidade atrophiou-se. Pela sua missão eminentemente universal, conservou, pelo costume, pela deferencia, pelo consentimento commum, certas attribuições internacionaes. 
Poderemos pois, denominar a Santa Sé uma pessoa sui generis, honoraria de Direito Internacional.

Quanto aos enviados diplomaticos junto da Santa Sé e ás concordatas, sẫo pontos de que nos occuparemos mais tarde.

\section{RECONHECIMENTO}

\section{Doutrinas}

1. ${ }^{\mathrm{a}}$ - Basta formar-se um Estado, por exemplo desmembrando-se de uma pessoa internacional, para tornar-se outra, independentemente de reconhecimento (Hall, Gareiss, etc.). Apenas o Estado não pode entrar em relação com os outros membros da Familia das Nações que não o reconheceram.

$2 .^{a}$ - O Estado só se torna pessoa internacional, pelo reconhecimento.

"Reconhecimento é o acto pelo qual fica claro que um Estado antigo está disposto a tratar um outro como membro da Familia das Nações (Oppenheim)"

\section{ESPECIES}

Expresso ou tacito.

O reconhecimento não é obrigatorio.

Pode ser dado sob condiçóes. O Congresso de Berlim, reconheceu em 1878, a Bulgaria, o Montenegro, a Servia, a Rumania, sob a condição de não fazerem persiguiçōes religiosas.

$\mathrm{O}$ momento em que deve ser feito o reconhecimento depende de caso especial. - $\mathrm{Ha}$ reconhecimentos precipitados e tardios. 
0 reconhecimento dos Estados Unidos pela França em 1778 foi precipitado.

Mas se fosse feito em 1782 já não seria inopportuno pois a metropole já os reconhecêra.

\section{MUDANÇA NA CONDIÇÃO DAS PESSOAS INTERNACIONAES}

A existencia das pessoas internacionaes tem mudanças importantes e indifferentes.

Ha mudanças nos cidadâos, governo, territorio. Estas mudanças são indifferentes, e não affectam a existencia da pessoa internacional.

\section{MUDANÇAS NO TERRITORIO}

Pela continuidade do Estado não affectam a personalidade internacional.

A Prussia pela Paz de Tilsit de 1807 perde a terça parte do territorio. O Reino da Saxonia, pelo tratado do Vienna, perde a metade do seu territorio; a Austria, em 1859, perde a Lombardia, e em 1866, Veneza.

Estas mudanças, conservada a continuidade do Estado, não affectam a personalidade internacional. Martens, 1 - 68, Rivier. - Moore $\$ 76$.

\section{MUDANÇAS NA POPULAÇÃO}

Renova-se a população sem que a personalidade inter: nacional seja affectada. A Prussia, por exemplo, no tempo do grande Eleitor, recebe os protestantes francezes e o Estado mantem-se o mesmo. Outro exemplo é Genova no seculo 16. 


\section{$-75-$ \\ MUDANÇAS NO GOVERNO}

Não affectam. Pelo principio da continuidade do Estado este continua obrigado pelos actos do governo que deixou de existir. Exemplo: O governo restaurado é obrigado pelos actos do usurpador. Luiz XVIII e L. Phillippe, indemnizaram os prejuizos dados por Napoleão - 0 Rei das duas Sicilias pagou aos americanos os prejuizos de Murat Rivier, 1.102 - Sobre indemnizações França, Moore. Int. Arb. - V. 4399 e 4862.

Republica Brasil. A Republica proclamada respeitou todos os compromissos do Imperio. Tel. Ruy Barbosa, Mr. Blaine, Sec. Est., 23-Novembro.

Estas mudanças, podem ser importantes para o Estado, mas pelo principio da sua continuidade, não interessam ao Direito Internacional, e não affectam a sua personalidade internacional. Estas mudanças podem ser tão importantes que, como vimos, quando o Estado não reconhece o governo, é impossivel ter com elle relações internacionaes.

\section{MUDANÇAS QUE AFFECTAM A PERSONALIDADE INTERNACIONAL.}

Quando dois Estados tornam-se uma unica pessoa internacional (União Real).

\section{PERDA PARCIAL DA INDEPENDENCIA}

Muitas restricções podem ser postas aos Estados sem perda da sua independencia, mas certas outras envolvem perda parcial della, quando, por exemplo, o Estado soberano torna-se semi-soberano. 


\section{ESTADO NEUTRALIZADO PERMANENTEMENTE}

Ficam independentes mas a sua personalidade internacional fica alterada, tornando-se pessoas internacionaes de uma classe especial.

\section{EXTINCÇÃO DAS PESSOAS INTERNACIONAES}

Os Estados deixam de ser pessoas internacionaes, quando deixam de existir. Theoricamente é possivel a extincção pela emigração de toda população ou anarchia permanente - Practicamente é difficil - Casos:

1 - Incorporação voluntaria a outros Estados - Texas incorporado aos Estados Unidos em 1843, - Ducado da Curlandia em 1795 á Russia - Prinaipados de Hohenzollern - Helchingen e Hohenzollern Sigmaringen 1850 á Prussia - Estado Livre do Congo em 1908 á Belgica - Korea em 1910 ao Japão.

2 - União de varios Estados num unico: - Italia.

3 - Por divisão voluntaria de um Estado em varios: Maior republica America Central, Russia, etc.

4 - Por- incorporação forçada de um Estado a outros:

Absorpção da Polonia, em 1795, pela Russia, Austria e Prussia. Por incorporação forçada, temos o Estado livre de Orange e a republica Sul Africana em 1901 á Inglaterra.

\section{FONTES}

Bonfils-Fauchille, ns. 160-164, 195-213 e 214-215. Oppenheim, I p. 125 e seguintes. 


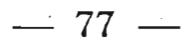

PONTO $7 .^{\circ}$

\section{PRINCIPIO DAS NACIONALIDADES}

\section{DeFINIÇÃa}

" $E$ ' o principio em virtude do qual os Estados devem corresponder ás nacionalidades" (Foignet).

\section{OrigeM}

A idéa de nacionalidade nasceu durante a revolução franceza, e já Mme. de Staël dizia que cada Estado deve comprehender um povo com uma lingua e costumes semelhantes.

Depois de 1815, e cada vez mais, foi triumphando. este principio, principalmente depois que Napoleẩo IIL lhe deu o seu apoio.

\section{ManCINI}

Coube 'a gloria de formular este principio a Mancini.

Na celebre licção de 22 de Janeiro de 1851, Mancini ensinou que a idéa de nacionalidade deduzida do Direito Internacional, uma especie de Direito Universal, é elementar, e a idéa do Estado é derivada. "Della Nazionalitá come fondamento del diritto delle genti" (Turim1851).

\section{Critica}

0 principio das nacionalidades foi formulado em épochas anormaes, de fermentação e de paixões. Mancini, levado pelo seu patriotismo foi longe de mais e em vez de retratar um principio, caricaturou-o. 
Os italianos quizeram provar que os esforços da Italia para libertar-se e unir-se eram legitimos, e appellaram para este principio.

Mas, parece-me, com $V$ Bulmering, que, para unir-se a Italia, não era necessario basear-se o Direito Internacional no principio das nacionalidades.

\section{IMPORTANCIA DO PRINCIPIO}

O principio fez carreira: "Este principio é glorificado durante o sec. XIX como o mais razoavel fundamento para regular todas as controversias possiveis entre os Estados, e para restabelecer uma ordem que garanta a cada povo um desenvolvimento pacifico, em synthese, como uma especie de panacéa contra todas as velleidades de desaccordos internacionaes" (Martens).

\section{INFLUENCIA}

Predominou completamente o principio depois de 1877, e sob a sua influencia desmembrou-se o Imperio Ottomano e unificaram-se a Italia e a Allemanha.

\section{Atàues aO PRINCIPIO}

Os europeus atacam muitas vezes o principio das nacionalidades e tambem o direito dos povos de se governarem a si mesmo. Mas, ha, no caso, muito interesse e bôa dose de má fé. 0 principio das nacionalidades não é a base do Direito Internacional, nem mesmo é um principio juridico, é apenas um principio politico.

Mas, a sua importancia é enorme e grande a sua influencia na historia do Direito das Gentes e na marcha da civilização. 
Como DEve SER Comprehendido. - A idéa de nação é complexa, antes psychologica que juridica.

Uma nação é uma alma, uma familia espiritual, resultante, no passado, de lembranças, de sacrificios, de glorias, ás vezes de dores e recordaçôes communs; no presente, do desejo de continuar vivendo juntamente. $O$ que constitue uma acção, não é o facto de falar certo numero de pessoas a mesma lingua ou pertencer ao mesmo grupo ethnographico; é ter feito juntamente grandes coisas no passado e querer ainda fazel-as no futuro. A nação é um principio esptritual resultando de complicações profundas da historia. (Renan, Discours et Conférences). Como estamos longe dos que fallam em pan-slavismo ou pan-germanismo como consequencia do principio ..

E' do ponto de vista elevado de Renan que devemos estudar a materia e conceber o principio das nacionalidades.

O EXEMPLO SUISSO..

A Suissa, amalgama de povos differentes, é o exemplo mais acabado de uma nação, tal como a concebemos, e talvez a mais legitimamente constituida da Europa, como affirmava o mesmo Renan.

\section{Palavras de Nippold}

"On a voulu nous contester la qualité de nation parce que notre pays se compose de peuples différents par la race et par la langue. Et pourtant nous nous sentons une nation aussi bien qu'un peuple qui ne parle qu'une seule langue. Bien que trois civilisations soient répresentées en Suisse, nous avons conscience d'être unis par une histoire commune, dont nous sommes fiers, par l'amour commun de la liberté et de nos institution democratiques. Les suisses allemands se sentent une même nation en depit de la différence de langage" 


\section{A Suissa e a Sociedade das Nações}

E' de notar como observa, Nippold, que a Suissa com as suas 3 raças e as suas 3 culturas forma uma Sociedade das Nações em miniatura. Prova que apesar dessas differenças pode-se viver em boa harmonia, que um $\mathrm{Di}$ reito Internacional mais elevado do que o que existe actualmente não é uma impossibilidade, assim como uma sociedade das Nações na sua verdadeira accepção.

Oxalá se entendesse sempre assim a idéa de nacionalidade. Bem comprehendida significa a paz, mal oomprehendida, o odio, a paixão, a guerra.

\section{A grande guerra E o problema das Nacionalidades}

Durante a conflagração europea, mais de uma vez foi proclamado o direito das nacionalidades pelos Alliados.

"Il n'y a pas de paix possible tant que ne seront pas assurées la reparation des droits et libertés violés, la reconnaissance du principe des nationalités et la libre existence dest petits états" (Nota de 30 de Dezembro de 1916). Assim, de accordo com essa politica, formaram-se a Nação polaca et a tcheco-slovaquia.

0 governo provisorio russo em declarações de 9 de Abril e 18 de Maio de 1917 reconheceu tambem ol direito dos povos de disporem de seus proprios destinos.

\section{WILSON}

Mas o maior paladino do direito dos povos foi o grande idealista $W$ ilson.

A sua doutrina illuminou o mundo durante algum tempo, foi o verbo da paz, a palavra da justiça. 
A doutrina Wilsoniana foi acceita pelos allemães e austriacos (notas de 12 e 27 de Outubro de 1917) e pelos alliados (nota de Lansing a Sulzer 6-Novembro-1918).

Wilson limitava a soberania do Estado pelo direito superior da Humanidade.

\section{Palavras de Wilson}

A America combate " pour la libération des peuples, quels qu'ils soient, des aggresions de la force autocratique" (Dec. 9-1-1917, á Russia).

Em Mont-Vernon, no discurso de 4 de Julho de 1918, preconiza a "destruction de tout pouvoir arbitraire en quelque lieu que ce soit, qui puisse isolément, secrètement et de par sa seule volonté troubler la paix du monde"

"Todo povo tem o direito de escolher a soberania sob a qual é chamado a viver" (27 de Maio de 1916).

Esta ultima declaração foi modificada posteriormente.

\section{O discurso de 22 de JANEIRo de 1917.}

"Uma salvaguarda inviolavel da existencia do culto e do desenvolvimento social e industrial deveria ser garantida a todos os povos que viveram até aqui sob o dominio de governos ligados a uma fé e a fins politicos differentes, dos seus" Ahị falla Wilson não em independencia plena mas sim em um minimo de direitos (uma autonomia).

Em geral, a doutrina Wilsoniana oppõe aos direitos das nações os do Estado, e delimita estes dois direitos pelo fim commum da Humanidade.

Mas como?

Mensagem presidencial de 11 de Fevereiro de 1918.

De accordo com a mensagem de 11 de Fevereiro dt: 1918, como muito bem diz Mandelstan, o illustre interra- 
cionalista russo, no seu curso na Academia de Direito Internacional de Haya (1923), monumental trabalho que muito me tem servido na exposição da materia: "Cada parte do regulamento final deve ser baseada sobre a justiça do caso particularmente considerado, e arranjos mais adaptaveis á consecução de uma paz permanente" (ponto 1).

"Todas as aspirações nacionaes bem definidas deverão receber a satisfação mais completa possivel sem introduzir ou perpetuar antigos elementos de desordem ou de antagonismo, susceptiveis, com o tempo de romper a paz da Europa e portanto do mundo" (ponto $4 .^{\circ}$ ).

\section{Conclusão da doutrina Wilsoniana}

"Em summa, a doutrina wilsoniana reconhece em principio a necessidade de satisfazer as aspirações nacionaes; mas reserva o exame da "justiça éssencial de cada caso particular", e l:mita essas aspirações pelos interesses superiores da paz mundial.

Segundo a doutrina wilsoniana em caso de conflicto entre o Estado e as nações que fazem parte delle, a solução rễo será uniforme: cra será favoravel ao Estado, ora á nação - segundo os interesses superiores da sociedade $h u$. mana"

\section{LiCÇão da historia do Direito Internacional}

Sabemos já, pelo estudo da historia do Direito Internacional, que é inutil combater o principio das nacionalidades (Oppenheim).

A sua verdadeira noção já foi por nós dada anteriormente. Contra elle se ergueram as grandes potencias, riscando do pacto da Liga das Nações o artigo 21 da sua primitiva redacção. Mas, em vão. 
Quando um povo, com uma concepção nitida de seus destinos, com aptidão para viver, cheio de forças e ideaes, com uma comprehensão clara de sua nacionalidade, qus é um factor psychologico importantissimo, deseja tornar-se livre, não ha obstaculos, não ha" forças humanas que o vençam: mais cedo ou mais tarde será livre.

$\mathrm{Si}$ os escriptores europeus combatem o principio das nacionalidades, é para defender interesses inconfessaveis. As populações opprimidas hão de se erguer contra a cobiça insaciavel das grandes potencias, e reduzir a nada os que combatem o principio das nacionalidades. futuro.

Este, vencedor no passado, será tambem vencedor no

\section{FONTES}

Bonfils-Fauchille, ns. 20 e sets.

Mancini, op. cit.,

Despagnet, I p. 133.

Nys.

\section{PONTO $8 .^{\circ}$}

\section{SUCCESSÃO DAS PESSOAS INTERNACIONAES}

Não ha accordo entre os escriptores sobre a successão das pessoas internacionaes.

A doutrina mais commum comtudo é a que vou expor em seguida.

Dá-se uma successão de pessoa internacional quando uma ou mais pessoas internacionaes tomam o logar de uma outra pessoa internacional, em consequencia de qualquer mudança na condição desta (Oppenheim). 
A successão pode ser:

$10^{\circ}$ - Universal - quando uma pessoa internacional é absorvida por outra, por incorporação voluntaria ou forçada, e tambem quando um Estado se fracciona em outros que se tornam pessoas internacionaes, ou são absorvidos, annexados por outros Estados.

$2 .^{\circ}$ - Parcial - a) quando uma parte do territorio se torna independente; b) quando uma pessoa internacional adquire uma parte do territorio de outra por cessão; c) quando um Estado soberano entra para uma federação; d) quando uma pessoa internacional entra para uma reunião real, ou vice-versa.

Ninguem sustentará hoje que, em Direito Internacional, haja uma successão de todos os direitos e obrigações. $\mathrm{Na}$ materia, tudo depende, como ensina Oppenheim, que sigo nesta lição, ddo caso especial.

Alguns autores comtudo dizem que nunca ha successão de pessoas internacionaes (Gareiss, 65-69).

Ensinam elles que, com o desapparecimento da pessoa internacional, desapparecem tambem todos os seus direitos e obrigações.

Si não existe uma successão universal, é comtudo absurdo negar que haja successão de pessoas internacionaes. Basta observar o que se passa na realidade.

\section{Casos}

Vejamos os casos de successão:

1. - Absorpção - Quando um Estado é absor. vido por outro, extingue-se como pessoa. 
Direitos e obrigações decorrentes do caracter de pessoa internacional ou tratados puramente politicos, extinguem-se.

Assim os tratados da alliança, neutralidade e arbitramento, extinguem-se.

\section{$E$ os tratados commerciaes?}

Ha discussão. Acho que, comquanto não sejam tratados puramente politicos, têm traços proeminentemente politicos, devendo extinguir-se todo tratado commercial com a extincção das pessoas internacionaes.

Dá-se tambem uma successão quanto aos direitos obrigações localmente connexas com a terra, os rios, as estradas, etc.

Os tratados de limites, reparação de estradas, navegações fluviaes, ficam validos, e ha successão de accordo com o principio res transit cum suo onere.

Ha tambem successão da propriedade fiscal e fundos publicos que entram para o patrimonio do novo Estado (Dec. Alta Corte U. S. A. no U. S. v. Prioleau, V Scott, Cases on Int. Law pag. 85).

Por uma regra baseada em costume, ha successão das dividas (Moore Appleton). Estado.

0 credor privado não adquire direitos contra o novo

Alguns, (Hubero, Heffter, etc.), acham que o Estado successor deve ficar com as dividas, mesmo quando o patrimonio é inferior a ellas. Mas esta opinião não é sanccionada pela pratica.

Um Estado que subjuga outro tem que ficar com as dividas de guerra (Oppenheim contra Westlake) - No caso de federação, tudo depende de circumstancias especiaes. Ha ainda a considerar si a federação é de typo ameri. cano ou germanico. 
Sobre concessões a individuos e companhias, tudo é fallivel (Moore, Fidel, Westlake).

2..$^{\circ}$ - Desmembramento - Quando um Estado se desmembra e fórma varias pessoas internacionaes, ou é annexado por outros, extingue-se, e applicam-se-lhe as mesmas regras da absorpção.

Quando o territorio do Estado extincto é absorvido por varios Estados, dá-se a successão dos direitos localmente connexos com a parte dos territorios absorvidos pelos respectivos Estados, da propriedade fiscal e fundos do Estado e uma divisão proporcional das dividas.

Quando se dissolve uma União Real, como a Suecia e Noruega em 1905, ha successões e todos os tratados obrigam os antigos membros excepto os feitos pela União para um unico membro.

3. - Separação e cessão - Ha successằo dos direitos localmente connexos com o territorio, da propriedade fiscal e dos fundos publicos.

Parece que uma parte das dividas deve ficar a cargo do successor, não havendo comtudo nada de fixo a respeito.

O tratado de Berlim de 1878, estipulou, nos arts. 9, 33 e 42, que a Bulgaria, o Montenegro e a Servia ficariam com uma parte da divida turca.

De modo contrario procedeu a America do Norte em 1898, quanto á divida Cubana (Moore, III $\$ 97$ pags. 355 e 385 e v. 1 § 97).

Comtudo Hubero sustenta que ha uma regra de Direito Internacional que obriga no caso de separação ou cessão a ficar o successor com uma parte da divida do predecessor.

Como vimos, esta opinião é contestada por Oppenheim e outros. 


\section{FONTES}

Grocio, IIc. 9 e 10. - Phillimore, i §' 137 - Moore, D. Wharton - Westlake, - Halleck - Ullmann - Gareiss - Bonfils, - 216 - Despagnet, 89 - Nys, 1 bag. 393, Liszt - Fiore - Rivier - Cruchaga.

$$
\text { PONTO 9. }
$$

\section{Classes de Estado}

Os Estados são simples ou compostos (noções dadas no $1 .^{\circ}$ anno).

Os Estados compostos são:

União real e estado federal.

A união pessoal e o Estado confederado não são pessoas internacionaes.

\section{UNIÃO PESSOAL}

Dá-se a uniâo pessoal quando dois ou mais Estados soberanos e pessoas internacionaes separadas, unem-se pelo facto accidental de terem o mesmo individuo para Monar. cha. Exemplo: Grä Bretanha e Hanover, de 1714 a 1837.

\section{Posiçấo INTERNACionaL}

São pessoas internacionaes separadas. Podem mesmo fazer-se a guerra. São muitas vezes representadas por identicos agentes diplomaticos, mas estes representam não a união pessoal mas sim cada um dos Estados separadamente 


\section{UNNIĀO REAL}

Denomina-se união real a reunião de dois ou mais Estados soberanos, por tratado internacional, reconhecido pelos outros Estados, para formar exteriormente uma unica pessoa internacional. As leis e instituições politicas do Estado mantêm-se distinctas. No interior, em resumo, varios Estados soberanos; no exterior, um unico: - a união real. Exemplo: Suecia e Noruega. Tornaram-se união real em 1814.

Dissolvida pacificamente em 26 de Outubro de 1905, (Tratado de Stockolmo, conclusão das reuniões de Karlstad).

Austria-Hungria - Tornou-se união real em 1723. Terminou, depois de varias vicissitudes, com a grande guerra.

\section{Confederação}

"Confederated states (Staatenbund) are a number of full sovereign states linked together for the maintenance of their external and internal independence by a reconised international treaty into a union with orgams of its own, which are vested with a certain power over the member states, but not over the citizens of these states" (Oppenheim, Int. Law, I p. 156). Ou, em portuguez:

"Confederação é a reunião de Estados soberanos por tratado internacional para manter sua independencia interna e externa, formando uma união, com orgãos proprios, com poderes sobre os Estados membros, mas não sobre os cidadãos desses Estados"

\section{Posição INTERNACIONAL}

Não é uma pessoa internacional, como vimos. Exernplo: Estados Unidos de 1778 a 1787, Allemanha, 1875 a 
1866. Suissa - 1921-1798 e 1815-1848. Maior Republica da America Central (Honduras, Nicaragua e Salvador) de 1895-1898.

\section{Federação}

"A Federal State is a perpetual union of several sovereign States which has organs of its own and is invested with power, not only over the member-States, but also over their citizens" (Oppenheim, I p. 157).

“Estado Federal, é a reunião perpetua de varios Es. tados soberanos, com orgãos proprios não só sobre os Estados membros como sobre os individuos desses Estados"

Esta doutrina é a ideada pelo Federalista e acceita por Kent e Story as maiores autoridades de Direito Constitucional na America.

A soberania está dividida entre a União e os Estados.

E' o caso da nossa Constituição.

A soberania no Brasil está dividida entre a União e os Estados, sendo cada um soberano na sua esphera.de acção.

Essa distincção entre federação e confederação pode ser estudada em Lafayette, $\oint \oint 35$ e 36, onde explica a materia de accordo com minha doutrina, bebida aliás nas fontes americanas.

Ha duas especies de federação: as de typo germanico e as de typo americano.

$$
\begin{aligned}
\text { Exemplo: - } & \text { Estados Unidos (1787) } \\
& \text { Suissa (1848) } \\
& \text { Brasil (1891) } \\
& \text { Argentina (1860) }
\end{aligned}
$$




\section{Allemanha}

Batida na grande guerra, com a mudança da forma monąrchica para a republicana (1918), em 11 de Agosto de 1919 teve a sua constituição. Essa constituição allemã unificou o antigo imperio.

A Allemanha é hoje uma fiederação, mas tende a tornar-se um Estudo unitario.

\section{RUSSIA}

E' hoje tambem una federação, mas a sua situação não está definida em Direito Internacional.

\section{Estados PRotegidos}

"Estado protegido é o que, por não ter força sufficiente para sustentar a sua independencia, defender o seu territorio, ou ainda resguardar-se da oppressão e injurias, se colloca sob a protecção de um Estado mais poderoso mediante condiçōes definidas" (Lafayette, § 37).

\section{Estados NEUTROS}

Estados neutralizados são aquelles cuja independencia e integridade ficam para sempre garantidas pelas maiores potencias, sob condição de nunca pegarem em armas contra outros Estados, ou celebrarem tratados dos quaes possa resultar guerra (v. Oppenheim, v. I p. 171). Exemplo: Suissa.

\section{A Suissa}

A Confederação Suissa, desde a Paz de Westphalia de 1648, seguiu sempre uma politica de tradicional neutralidade. Intervenção franceza - Republica Helvetica. 
Neutralização - Foi reconhecida por um Acto assig. nado em Pariz pela Austria, França, Grã Bretanha, Prussia, e Russia, em execução da Declaração de Vienna de 20 de Março de 1875, confirmada pelo art. 84 do Acto de Vienna.

\section{Belgica}

Neutralizada pelo Tratado de Londres 15 Novembro 1831 (art. 7. ${ }^{\circ}$ ). A sua neutralidade é garantida no art. 25, pela Inglaterra, França, Prussia e Russia e renovada à garantia em Londres no tratado de 19 de Abril de 1839 art. 2. 1914.

A sua neutralidade foi violada pela Allemanha em

Terminada a grande guerra, a Belgica deixou de ser um paiz neutro.

\section{Estados NÃO CHRISTÃOS}

Excepto a Turquia e o Japão, plenamente soberanos e tratados em pé de perfeita igualdade pelos outros Estados membros da Familia das Nações, os outros Estados não christãos occupam uma posição duvidosa.

A posição internacional da China, do Siam, da Per. sia e da Abyssinia, é duvidosa. Devem comtudo os Estados tratar com ellas de accordo com os principios da $\mathrm{Mo}$. ral Christã. O Siam, a China e a Persia são membros da Liga das Nações, e procuram por todas as formas assimilar os principios da Moral Christã e a nossa civilização. Basta considerar que até mandaram representantes estudar na Academia de Direito Internacional de Haya, o que só fez o Brasil muito recentemente, este anno, por iniciativa e esforço do professor de Direito das Gentes. Não devem ser tratados nem os povos não christãos, nem mesmo os povos barbaros, discrecionariamente $(\mathrm{V}$ e artigo - $A$ oppressão das grandes potencias). 
"Mais si un peuple est tellement barbare qu'il n'a pas d'organisation du tout, ses membres ne saurient être protégés que par les principes de la morale et de la religion, les mêmes principes devant être appliqués quand'il s'agit de leur châtiment" (Lord Phillimore, Curso na Academia Direito Internacional de Haya)

\section{A Santa Sé}

A posição internacional da Santa Sé é toda especial. linhas.

Resumiremos o que ha sobre a materia em poucas

Os antigos Estados do Papa. Outr'ora foi o Papa um Monarcha como outro qualquer. Os Estados do Papa foram creados por Pepino o Breve e Carlos Magno, em favor de Estevam II e Adriano I, pelos quaes foram coroados. Em 1798, e por 3 annos, tornaram-se Republica.

Voltaram os Papas a reinar em 1801, até que os Estados do Papa foram annexados por Napoleão I em 1809.

A antiga ordem de coisas permaneceu depois de 1814 até 1870, quando foram absorvidos pela Italia.

\section{SITUAÇÃo INTERNACIONAL}

Tendo uma missão universal, pelo consenso das nações cultas, pela tradição, tem o Summo Pontifice uma certa posição internacional, é considerado um verdadeiro Monarcha. Mas, pelo seu caraoter especial, a Santa Sé é uma pessoa sui generis, anormal, podemos talvez dizer, honoraria, de Direito Internacional.

A opinião de Lord Phillimore

No seu curso na Academia de Direito Internacional affirmou Lord Phillimore que é identica á posição do Papa, 
á de Sua Beatitude o Patriarcha de Constantinopla e o Khalifa, para os Mahometanos.

Não creio que a missão desses chefes de religióes seja identica á do Papa.

\section{FONTES}

Oppenheim, 1 p. 152

Bonfils - 165 e seguintes.

PONTO $10 .^{\circ}$

\section{DIREITOS DOS ESTADOS}

Sustentam muitos jurisconsultos que existem direitos fundamentaes dos Estados.

Mas, quando tratam elles de dizer quaes esses direitos fundamentaes, entram em grandes divergencias.

Em geral, dizem que são o direito de existencia, o de independencia, o de conservação, o de intercurso, o de boa reputação etc.

Mas, como observa Oppenheim, não ha accordo entre elles na enumeração desses direitos que pretendem ser fundamentaes

Porisso esses jurisconsultos começam geralmente fazendo uma pequena critica da opinião dos outros sobre os direitos fundamentaes, o que fez alguns dizerem que da critica dos defensores dos direitos naturaes dos Estados resultou o desapparecimento delles dos livros de Direito Internacional.

Acho que não existem direitos fundamentaes dos Estados. 
O Direito Internacional, como já explicámos ao tratar do seu fundamento, originou-se do consentimento commum dos membros da familia das nações desenvolvendose historicamente ao influxo da civilização christã.

Os povos adoptaram os principios christãos como poderiam adoptar outros.

Observou-se que eram os melhores, os que mais asseguravam as condicões de vida e desenvolvimento do individuo e da sociedade, e que os povos mais adiantados poderiam progredir com esses principios. $\mathrm{E}$ assim aconteceu, porque os povos christãos foram, e são, os mais civili. zados da terra. $\mathrm{E}$ mesmo os povos que posteriormente entraram para a familia das naçōes tiveram que adoptar expreşa ou tacitamente os principios christãos nas relações internacionaes.

Mas, não existe uma moral absoluta, um direito $a b$. soluto, immutavel. A propria moral christã tem sido modificada, e grandemente, com o correr dos annos.

Não existem direitos fundamentaes, existem direitos que foram adoptados pelos povos civilizados.

Observou-se que os povos só podem viver e progredir em sociedade, e que, para um povo viver na sociedade internacional, precisa respeitar os direitos dos outros povos, limitar a sua liberdade de acção. Todo povo portanto pode agir livremente, desde que não venha ferir direitos dos outros povos.

Isso é elementar em Direito.

Vejamos pois quaes os direitos dos Estados.

Egualdade, honras e titulos.

A egualdade dos Estados resulta da personalidade internacional.

Temos como consequencia: 
1..$^{\circ}$ quando surge uma questão que tem que ser resolvida pelo consentimento commum dos membros da familia das Nações, cada Estado tem um voto, e um unico voto;

$\left.2^{\circ}\right)$ legalmente o voto do Estado mais fraco é egual ao do mais forte;

$\left.3 .^{\circ}\right)$ em consequencia da regra par in parem non habet imperium, nenhum Estado tem jurisdicção sobre outro plenamente soberano.

Comquanto um Estado possa demandar em tribunal extrangeiro (Phillimore, II $\S 113$ a; Nys; Oppenheim), não pode em regra ser demandado, salvo quando acceita voluntariamente a jurisdicçäo do tribunal extrangeiro, ou se submette a elle, demandando em tribunal extrangeiro.

Honras - Como na sociedade dos individuos, na dos Estados ha certas distincções.

Hoje essas honras não tem mais tanta importancia como no passado. Nos seculos 16 e 17 discutiu-se muito a questão do Droit de preséance (questions de préséance).

O Congresso de Vienna de 1815 quiz regular a materia, mas encontrou difficuldades insupperaveis. $\mathrm{O}$ assumpto é hoje regulado pela pratica.

Ha Estados com honras reaes e Estados sem honras reaes.

São Estados com honras reaes, os Reinos, Imperios, as grandes republicas e a Santa Sé.

Só os Estados com honras reaes enviam agentes diplomaticos de $10^{a}$ classe (embaixadores), e têm precer dencia. 0 "Alternat" (alternado). Para evitar as questóes de precedencia os Estados da mesma categoria assignam alternadamente, assignando em $1 .^{\circ}$ logar o representante do Estado a quem se destina o original.

A assignatura pode ser ainda pela ordem alphabetica (em francez), ou ainda pêle-mêle (desordenadamente). 
Titulos - Hoje os Estados geralmente não têm titulos, mas estes existem antigamente, e em larga escala.

Genova e. Veneza eram "Serena Republica", S. Marino "Serenissima Republica"

Quanto aos titulos, cada Estado pode dar ao seu chefe o titulo que entender, mas este só será reconhecido pelos outros Estados si estiver de accordo com a realidade. Por exemplo, em 1871, o Rei da Prussia tomou o nome de Imperador da Allemanha; em 1877, o Rei da Inglaterra tomou o titulo de Imperador das Indias; em 1881, o Principe da Servia tomou o titulo de Rei, e o mesmo fizeram os da Rumania, da Bulgaria e do Montenegro, respectivamente em 1882, 1908 e 1910.

$\mathrm{O}$ reconhecimento de titulos é facultativo, havendo exemplo de reconhecimentos tardios e de não reconhecimento.

Pedro, o Grande, tomou em 1701, o titulo de Imperador da Russia, mas esse titulo só foi reconhecido pela França em 1745, pela Hespanha em 1759 e pela Polonia em 1764. O titulo de Rei da Prussia, tomado em 1701, só foi feito reconhecido em 1786 pelo Papa. Os Imperadores e Reis têm Majestade, o Papa é Santidade, segundo determina o Direito Internacional.

Mas, alem dos titulos de Direito Internacional, ha os titulos dados pelos Papas, que nenhuma importancia têm para o Direito Internacional. Por exemplo o Rei da França era "Rex Christianissimus"; o da Hespanha depois de 1496 "Rex Catholicus"; o da Inglaterra (1521) "Defensor Fidei"; o de Portugal (1748) "Rex Fidelissimus"; o da Hungria (1758) "Rex Apostolicus"

\section{DIGNIDADE}

Quasi todos os autores falam em um direito funda. mental de reputação e bom nome. Mas tal direito não 
existe evidentemente. $\mathrm{Na}$ sociedade dos Estados, como na dos individuos, o bom nome depende do bom procedimento. Mas existe no Estado uma qualidade que é a dig. nidade.

Si o Estado tem, como o individuo, dignidade, merece ser tratado com certa consideração.

Sendo a dignidade um attributo reconhecido pela familia da nações, os Estados nas suas relações observam, por costume, entre si, certas ceremonias, e concedem uns aos outros certos privilegios. Por exemplo: estado;

$\left.1 .^{\circ}\right)$ Honras e privilegios concedidos aos chefes de

2. ) Exterritorialidade dos agentes diplomaticos.

$\left.3 .^{\circ}\right)$ Respeito á bandeira.

$\left.4 .^{\circ}\right)$ Ceremoniaes maritimos.

Os ceremoniaes maritimos de que trataremos mais tarde, são hoje actos de mera cortezia. Veja-se sobrel elles Halleck.

\section{INDEPENDENCIA}

E' um direito evidentemente do Estado, tendo como consequencia o direito de legitima defesa, o de intercambio $\boldsymbol{e}$ o de jurisdicção.

Esses são os principaes direitos dos Estados.

Ha ainda um direito que é antes um dever, é o direito de intervenção. Trataremos delle quando tratarmos do dever de não intervenção.

\section{FONTES}

Clovis, I p. 65

Lafayette, I p. 85

Davis, p. 91 
PONTO $11 .^{\circ}$

\section{DEVERES DOS ESTADOS}

O $1 .^{\circ}$ dever do Estado é o de respeitar a personalidade internacional dos outros Estados que com elle coexistem na communhão internacional (Cruchaga), não podenda portanto um permittir que se preparem em seu territorio expedições contra outros Estados, ou que nelle sejam ultrajados' os seus representantes.

Como consequencia do dever de respeito á personalidade dos outros Estados “ os Estados não poderã̃o adoptar nome, bandeira, sello, ou qualquer signal pertencente a outro (Epitacio, Cod. art. 20)"

O 2.. dever é o de mutua assistencia, especiíalmente em relação aos navios que se refugiam em seus portos, em caso de naufragio, e para facilitar a _administração da justiça em materia civil e criminal (Bevilaqua, $1 .^{\circ}$ pag. 113, Cruchaga, pag. 119).

O 3. dever é o intercurso, porque um Estado não tem o direito de se isolar dos demais. Os Estados têm o dever de intercambio, mesmo commercial.

(Veja-se Davis, pag. 122. E tambem Vattel, l. II cap. II $\S 24$ - Halleck, pag. 404, Woolsey $\S \S 25,63$, 64; Lorimer, pag. 230; Klüber, $§ 69$, De Martens, $\S 139$ ).

$04 .^{\circ}$ dever é o de protedşão dos nacionaesi no extrangeiro (Bevilaqua 1. pag. 177; Cruchaga, 120; Grocio, II cap. XXV, Pomeroy, § 204; Hall, § 87; - Snow, pag. 625).

$05 .^{\circ}$ dever é o dever de não intervenção.

A materia de intervenção é complicadissimà.

"Intervenção é a interferencia dictatorial por parte de um Estado nos negocios de outro para mudar uma ordem de coisas" (Oppénheim, pag. 188). 
A regra é a formulada por Epitacio Pessoa:

"Nenhum Estado pode intervir nos negocios internos de outros" Mas si nas relações internacionaes a intervenção é a excepção e a não intervenção a regra' (Davis), em que casos poderá um Estado intervir nos negocios de outro?

Nunca será justa a intervenção?

\section{Casos de Intervenção}

Ahi começam as divergencias. Acho que, em certos casos extremos, é licita a intervenção (Pomeroy; Snow, pag. 57; Davis - Wheaton $\S 63$, Davis, Halleck).

Ha, em 1. logar, a intervenção em legitima defesa (Davtis, pag. 99, Twiss, $\S 107$, Hiall; Pomeroy).

Justifico ainda a intervençấo em prol dos sentimentos de humanidade. Mas para que seja justificada a intervenção neste caso é preciso:

1..$\left.^{\circ}\right)$ haver, uma intervenção diplomatica;

$2^{\circ}$ ) haver uma perseguição tão grande, selvagerias tão espantosas que revoltem os sentimentos do mundo civilizado; e

$\left.3 .^{\circ}\right)$ que a intervenção seja feita por todos os paizes christãos collectivamente.

E' a conclusão que tiramos do estudo e da reflexão Veja-se sobre a materia: Davis, pag. 103; Woolsey $\S 51$; Phillimore, $\S 400$; Creasy, $\S 308$; Hall, $\S 91$; Bevilaqua, 1 ' pag. 138.

Por conseguinte, a não intervenção é a regra, e a intervenção é a excepção, e só se justifica em casos extremos.

FONTES: 1 - Despagnet, 250

2 - Cruchaga, 123

3 - Holtzendorff, 75

4 - Lafayette, 92

5 - Woolsey, 43 


$$
\begin{aligned}
& -100- \\
& 6 \text { - Davis, } 98 \\
& 7 \text {-- Hall, pag. } 278 \\
& 8 \text {--. Westlake, } 1 \text { pag. } 304 \\
& 9 \text { - Kebedgy - De l'intervention. } \\
& 10 \text { - Nys, } 1 \text { pag. } 185 \\
& 11 \text { - Calvo, } 1 \text { \$ } 110 \\
& 12 \text { - Fiore - } 1 \text { e Cod. n. } .^{\circ} 543 \\
& 13 \text { - Mérignhac, } 1 \text { pag. } 248 \\
& \text { 14 - Bonfils, n. }{ }^{\circ} 295 \\
& 15 \text { - Wheaton, § } 63 \\
& 16 \text { - Halleck, pag. 94 - Manual e 1, } \\
& 17 \text { - Wharton, } 1 \text { pag. } 45 \\
& 18 \text { - Moore, VI } \oint \oint \text { 897-926. } \\
& 19 \text { - Ulmann § } 163 \\
& 20 \text { - Bluntschli, } 474 . \\
& 21 \text { - Gareiss, § } 26 \\
& 22 \text { - Drago, cobro coercitivo de deudas } \\
& 23 \text { - Vattel, II } \S 54 \\
& 24 \text { - Edgington's - Monroe Doctrine } \\
& 25 \text { - Grocio, II cap. } 20 . \\
& \text { PONTO } 12 .^{\circ}
\end{aligned}
$$

\section{RESPONSABILIDADE DO ESTADO}

O Estado é responsavel internacionalmente: é uma affirmação que podemos fazer sem temor algum.

O Estado póde modificar o D. Interno, mas não o Internacional, e, apesar de não haver uma autoridade superior aos Estados para os punir, ha os meios coactivos garantidos do D. das Gentes em geral, como ensinámos anteriormente. 
O D. I. exige que o Estado proteja os outros membros da communhão internacional, no interior do seu territorio, onde exerce a soberania, onde tem jurisdicção, contra os ataques á vida delles, á sua honra e á sua liberdade.

Exige mais o D. das Gentes que os Chefes de Estado e os agentes diplomaticos tenham, como representantes do Estado a sua vida, sua honra e a sua liberdade garantidas.

$\mathrm{E}$, finalmente os simples individuos que se fixam no territorio de um Estado com o seu consentimento, devem, mesmo sem tratado especial, receber a mesma protecção que os seus nacionaes, quanto á violação de seus bens juridicos, liberdade, honra e fäenda.

\section{Criterio}

A responsabilidade do Estado é determinada pelo facto de, na esphera dỏ exercicio de sua soberania, ser lesado um direito, que não poderia ser protegido sinão por elle.

\section{A culpa e a solução da Responsabilidade}

Solve-se a responsabilidade do Estado pela reparação ou pela satisfação.

Para que exista a reparação, é preciso que ao acto, delictuoso do individuo se ajunte a culpa do Estado, que elle não tenha tido as cautelas devidas (due diligence).

A satisfação não exigeı culpa do Estado.

\section{A CONVEnção de Haya}

A responsabilidade do Estado em tempo de guerra é reconhecida pelo art. $3 .^{\circ}$ da Convenção de Haya de 1907 "O belligerante que violar as determinações do 
dicto regulamento, pagará compensação. Será responsavel tambem por actos commettidos por pessoas que façam parte de suas forças armadas"

\section{ESPECIES}

Oppenheim divide a responsabilidade do Estado em $\rightarrow$ immediata, originaria, directa (original) e mediata indirecta, derivada (vicarious).

A directa ou originaria é a que tem d Estado por actos praticados pelo governo como representando o proprio Estado.

Subsidiaria é a derivada de actos praticados por individuos no Estado, mas agindo não autorizados pelo Estado, não como representando o proprio Estado, mas sim no seu caracter particular. Por esses actos ainda o Estado é responsavel pois o D. I. é um direito entre Estados, e os individuos são simplesmente objecto delle.

Essa distinç̧ão acceita por Borchad é atacada por Schoen e Anzilotti.

E' grande a differença entre as 2 especies. A $1 .^{a}$ é particularmente grave, é consequencia de actos do proprio Estado, é uma delinquencia internacional. A 2. ${ }^{a}$, não exige a culpa do Estado, e só se torna grave quando o Estado pactua com os violadores do direito, tornando-se assim a sua responsabilidade directa, immediata, originaria

Delinquencia Internacional “ é toda a injuria a um outro Estado commettida pelo seu chefe ou pelo seu governo, violando um dever internacional" (Oppenheim)

Equivalentes são os actos de officiaes ou mesmo individuos mandados ou autorizados pelos chefes do governo.

E' necessario não confundir com crimes internacionaes. 


\section{Casos de responsabilidade do Estado}

Estuda Oppenheim numerosos casos, todos interessantissimos: - orgãos aptos para commetter delinquencia, actos de officiaes administrativos e forças militares, etc.

Não nos poderemos deter em particularidades, nem mesmo estudar, como fizemos em aula, a responsabilidade do Estado por actos do parlamento e da imprensa, materia de grande actualidade e importancia.

Os actos dos parlamentos nunca trazem como consequencia a responsabilidade directa do Estado.

Nos paizes livres, a liberdade de imprensa isenta 0 Estado tambem da responsabilidade.

Mas num paiz como o Brasil onde já não existe essa liberdade, onde a imprensa está jugulada, onde a censura inconstitucional, como ensinámos no curso de D. Constitucional do anno passado, amordaça o jornalista, qual será a responsabilidade do Estado?

Parece-me que sempre directa. Só se publica o que deseja ou permitte o governo, o publicado é obra do proprio governo, e traz a sua responsabilidade immediata

Responsabilidade do Estado por operações de gúerra

A materia já foi por mim explanada no meu artigo publicado na Revista da Faculdade — Damnos por operações de guerra, vol. XXII.

FONTES: - Bonfils -- Fauchille, ns. 298 e segts. Oppenheim, I p. 242.

Despagnet, 466.

Arruda - Damnos por operações de guerra (Rev. Faculdade). 
PONTO 13.

\section{TERRITORIO E SUAS PARTES}

"Territorio é a porção definida da superficie do globo sobre a qual se extende a soberania do Estado." (Oppenleim).

Estado sem territorio é uma impossibilidade.

"O territorio comprehende:

1." o solo occupado pela nação;

$2 .^{\circ} \quad$ os rios, os lagos e 'os mares interiores;

3. $\quad$ os golfos, bahias e portos;

4. a faixa de mar exterior, que corre ao longo da costa, e que constitue o mar territorial;

5. a parte que o Direito attribue a cada Estado, sobre os rios, lagos e mares contiguos;

6." os navios nacionaes;

7 o espaço aereo correspondente ao territorio, até á altura determinada pelas necessidades da policia e segurança do paiz" (Clovis, 1." paragrapho 512).

Ninguem melhor que Epitacio synthetiscu as regras sobre o territorio:

"Artigo 29. O rio interior, com todo o seu curso no territorio de um Estado, está subordinado exclusivamente á soberania deste, ainda que seja navegavel, e se communique com o mar livre.

"Artigo 30. Si o rio atravessa successivamente terras de mais um Estado, cada um destes tem jurisdicção exclusiva sobre a parte correspondente ao seu territorio.

"Artigo 31. 0 thalweg é o limite da soberania nos rios que servem de fronteiras.

"Paragrapho unico. Si o rio abandonar o seu leito para seguir uma nova direcção, o leito abandonado pas- 
sará a constituir o limite dos Estados. Sendo entretanto pouco sensivet a deslocação a jurisdicção se regula pelo novo thalweg.

"Artigo 32. Os lagus interiores ainda que se com. muniquem com o mar estão sujeitos á soberania territorial. $O$ desaguadoiro de communicações rege-se pelas disposições relativas aos rios.

"Artigo 33. Quando o lago é situado na fronteira, a autoridade dos Estados confinantes vae até os mares, na extensão da testada de cada um.

"Artigo 34. Si a fronteira é formada por uma cadeia de montanhas, a linha do divorcio das aguas, marcará, salvo o que disponham os tratados, o limite da jurisdicção.

"Artigo 35. Os canaes estão subordinados á soberania do Estado cujo territorio atravessam" (Epitacio Pessoa, Codigo).

FONTES:

1 - Clovis, 1 p. 277.

2 -- Hall, p. 101

3 -Despagnet, n. ${ }^{\circ} 364$

4 - Bonfils, n. 483

5 -- Mérignhac; II, 356.

\section{O ESPAÇO AEREO}

\section{PONTO 14}

Quanto ao espaço aereo, ha grande controversia.

Em primeiro logar, pergunta-se a quem pertence a atmosphera? As respostas variam. Quando se tracta de saber quem exercerá a soberania sobre o espaço aereo, surgem logo as maiores difficuldades. 
E' evidente que, com o progresso extraordinario da aviação, essas difficuldades augmentarão neicessariamente: Com effeito, quem legislará para o espaço aereo?

Quem exercerá sobre elle a soberania?

A atmosphera não pode ser possuida por um unico estado, está claro. Mas, como dividil-a, de forma que sobre cada uma de suas partes exerça um Estado a sua soberania?

São questões complicądissimas portanto esisàs que são connexaś com a navegação aerea.

Se'assim é em tempo de paz, as difficuldades ainda augmentam em tempo de guerra.

Isso em Direito Internacional Publico. Em Direito Internacional Privado então as questões tornam-se interessantissimas, como veremos em breve.

Estudaremos a materia sómente em face do Direito Internacional Publico.

Apenas enumeraremos as questões que surgem em Direito Internacional Privado, que os Senhores talvez estudem no quinto anno.

A quem pertence o espaço aereo?

Vejamos, a quem pertence o espaço aereo, quem exerce a soberania sobre elle, sobre a atmosphera.

Discute-se si é dominio, propriedade, ou soberania, o direito que o Estado exerce sobre o ar (Nys, pag. 522).

O Estado pode exercer sobre a atmosphera que o cerca, a soberania. Mas, poderá exercel-a, e com que restrioşōes?

Surgem então as duvidas. Ainda, como ensina OPPENHEIM (pag. 237, 1. ${ }^{\circ}$ ), não existem regras fixas que resolvam convenientemente a materia.

\section{ESCOLAS}

Surgiram sobre o Direito Aereo, ainda na sua infancia, numerosas escolas. Geralmente comparam $a$ at- 
mosphera com o mar, distinguindo entre espaço sujeito, á soberania do Estado, i. e., espaço que se estende até uma certa altura, e espaço livre, comparavel ao mar livre.

Esta comparação entre o espaço aereo e o mar, como veremos dentro em pouco, é falha. Oppenheim e Edouard d'Hooghe, mostram como o mar' não pode ser comparado com à atmosphera.

Em primeiro logar, diz Oppenheim, o mar é uma grande estrada, que liga paizes distantes que sem ella não poderiam entrar em contacto, ao passo que a atmosphera não é uma estrada tão necessaria.

Em segundo logar, diz ainda Oppenheim, a navegação em alto mar não offerece perigo aos Estados, ao passo que a aviação pode ser perigosa, sob varios aspectos.

Vamos ver logo como resolve elle a questão.

Em primeiro logar vejamos as theorias sobre a nossa materia.

1." Theoria. -- Admitte que o espaço aereo não pode ser .objecto, estar sujeito a nenhuma soberania.

Dizem elles que o solo pode ser dividido geometricamente, mas que o mesmo não se pode fazer com a atmosphera, nem traçando linhas horizontaes, nem verticaes, porque essas linhas seriam puramente ideaes, visto não poder haver fronteiras reaes na atmosphera. $\mathrm{O}$ ar pode ser comparado an mar livre, é um oceano sem praias, cujo fundo é a terra habitada pelos homens.

Não pode haver occupação da atmosphera, a passagem do homem por ella, não deixa vestigios. $\mathrm{E}$ ' indivisivel por natureza, uma parte della não serviria a ninguem, toda serve a todos.

A sua posse é ainda mais difficil que o mar. Os homens podem, por meio de armas, dominar uma parie do mar. 
Por esta theoria, cada aeronave deve ser considerada como parte do seu territorio, sujeita á lei da sua nacionalidade unicamente (ou do seu domilicio, da nacionalidade do seu proprietario, ou da' sua matricula, como explicaremos).

Quando surgem conflictos entre aeronaves de pavilhões differentes, estes se resolvem como os que surgem entre navios de nacionalidades differentes navegando em alto mar.

Varias objecções podem ser feitas a esta doutrina.

Em primeiro logar, como nota d'Hooghe, não é verdade que o navio em alto mar tenha conflicto com os Estados, com a terra. Estes só são possiveis justamente no mar territorial.

Si a aeronave, fosse qual fosse a altura em que voasse, estivesse sujeita unicamente á sua lei, se tornaria insupportavel para os Estados sub-jacentes.

Os conflictos de leis seriam taes, que se tornaria impossivel a navegação aerea.

Por isso, diz d'Hooghe, seria muito mais util a existencia de uma legislação internacional uniforme.

2." THEORIA. - Esta theoria reconhece em principio a liberdade do ar sob a reserva dos direitos necessarios á conservação do Estado sub-jacente.

Foi a doutrina victoriosa no comité juridique international de l'aviation.

"La circulation aérienne est libre, saufi les droits pour les états sous-jacents de prendre certaines mesures à determiner en vue de leur propre sécurité et de celle des personnes et des biens de leuns habitants" (art. ler. du "Projet de Code internacional de l'air." Paris-Congrès Juin 1910). 
Semelhante é o principio do Instituto de Direito Internacional.

E' a doutrina de Meili, Stranz, Epitacio e outros.

Epitacio Pessoa, Cod., art. 57 diz:

"Cada Estado tem sobre o espaço aereo correspondente ao seu territorio, até á altura de mil e quinhentos metros, os direitos necessarios a sua conservação. A zona assim limitada tem o nome de zona de protecção".

Tambem segue esta theoria Clovis Bevilaqua $\left(v .1 .^{\circ}\right.$ pag. 217).

"O espaço aereo correspondente ao territorio, até a altura determinada pelas necessidades da policia e segurança do paiz" No §63 é mais desenvolvido: "O espaiso aereo, que se extende por cima do territorio do Estado, incluidas neste as aguas territoriaes, está submettido á jurisdicção do Estado sub-jacente, e, portanto, os vehiculos aereos, passando por essa parte da atmosphera, soffrem, como os navios, que transitam pelas aguas territoriaes, a acção da soberania local, que não pode, entretanto, prohibir a passagem innocua.

Estacionando em camadas atmosphericas sujeitas á jurisdicção de um Estado extrangeiro, os vehiculos aereos equiparam-se aos navios ancorados em porto extrangeiro.

Os vehiculos aereos militares equiparam-se aos navios de guerra"

$E d$. d'Hooghe distingue esta theoria da que assimila mais exactamente o ar ao mar, e procura completar o parallelo instituindo uma zona aerea equivalente ao mar territorial.

Mas essas duas doutrinas confundem-se perfeitamente: ambas reconhecem a liberdade do ar, ambas admittem que deve existir uma zona de proteç̧ão, ambas comparam o ar ao mar, e as aeronaves aos navios.

A unica differença seria que a $2 .^{: " ~ t h e o r i a ~ n a ̃ o ~ d a r i a ~}$ um limite fixo para essa zona, em altura está claro, e a $3 .^{\mathrm{a}}$ 
daria um limite fixo. Ora, essa differença é insignificante, por isso trataremos das duas theorias conjunctamente fundindo-as em 'uma unica.

Nessa theoria admitte-se a soberania territorial do. Estado sub-jacente, limitada no espaço pelas verticaes de suas fronteiras e no seu objecto pelo interesse ou necessidade desse Estado, por uma altura razoavel, indeterminada para uns, determinada para outros.

Existe, pois, uma zona de protecção, uma atmosphera territorial, sobre a qual o Estado exerce sua soberania, acima dessa zona, ha a atmosphera livre, o ar é Tivre, como é livre o mar alto.

Quando se tracta de determinar, de fixar a altura dessa zona de protecção, começam as duvidas.

Bluntschli, Pietri, Rivier, Hilty, Meyer e outros, dizem que a zona de protecção se extende até a altura em que o Estado pode fazer respeitar a' sua soberania da terra, i. e., a distancia dum tiro de canhão. (Um canhão Krupp attinge verticalmente 11.000 metros!) E' a applicação da maxima de Bynkershoeck concernente ao mar adjacente.

Paul Fauchile, admitte, a liberdade dos ares, mas tambem levando em conta o direito de conservação de cada Estado admitte uma zona de protecção de 1.500 metros.

Bonnefoy, Epitacio e outros, acceitam a mesma altura.

Holtzendorff, contenta-se com 1.000 metros, contados do ponto mais elevado, Von Barcom 50, ou 60 metros. Ainda Rolland fala na altura da Torre Eiffel, Von Listz na altura do dominio por aeronaves .. quanto arbitrio. $E d$. d'Hooghe, inclue Oppenheim nesta doutrina, mas erradamente pois Oppenheim não admitte a liberdade dos ares. Estudaremos dentro em pouco a theoria de Oppenheim. 
Essa theoria é absurda. O mar distingue-se perfeitamente da atmosphera.

Em primeiro logar, os navios em alto mar não podem prejudicar os Fstados que estão muito longe, ao passo que a passagem de um aeroplano a 2.000 metros pode ser nociva ao Estado sub-jacente. Um Estado não pode admittir nunca que se pratique contrabando ou espionagem a 1.500 metros do seu solo.

Em segundo logar, o mar é indispensavel para o commercio internacional, sem elle seria impossivel o contacto entre os continentes, o mesmo não acontecendo com o ar, que não é indispensavel ao commercio internacional.

Essa theoria é arbitraria tambem porque a superficie do solo varia muito, e alem do mais, a visibilidade, é possivel a 5.000 metros (Nys, $1 .^{\circ}$ pag. 530). A essa distancia pode se praticar perfeitamente a espionagem, ao passo que no man alto já não acontece o mesmo.

3: ' THEORIA - E' a theoria da soberania territorial.

Diz que o Estado não é soberano de uma superficie, mas sim de um volume, i. é, de uma pyramide determinada pelos raios terrestres, indo do centro do globo até o infinito passando pelos diversos pontos das fronteiras sobre o solo (Ed. d'Hooghe, pag. 6).

Bifurca-se como ensina d'Hooghe em duas sub-doutrinas. Uma, diz que essa soberania é temperada por uma servidão de livre passagem. Outra, diz que somente por uma concessão do Estado, e não por direito proprio, é que as aeronaves navegam o ar d'o Estado sub-jacente. Grunwald, Ullman, Gemma, Collard, Lycklama, Oppenheim, etc., adoptam á 2. ${ }^{\mathrm{a}}$, i. é, a da soberania territorial absoluta.

Meurer e Wiestlake, adoptam a $1 .^{a}$ (Ver d'Hooghe, pag. 6). 


\section{THEORIA DE ED. D'HOOGHE}

$\mathrm{O}$ eminente Presidente do comité Juridique International de l'Aviation, Ed. d'Hooghe, advogado em Douai e Doutor em direito, no seu mgnifica, trabalho "Droit Aérien", que tanto nos tem servido nesta insignificante licção, formula a sua opinião sobre a materia. Vamos transcrever a opinião de $d^{\prime} H o o g h e$, para não deturparmos o seu pensamento.

"Parece-nos que a preoccupação secreta, muitas vezes não formulada dos jurisconsultos, é inspirada pelo perigo do conflicto das leis. Admittir a soberania territorial, é correr o risco de que um Estado impeça arbitrariamente acima do seu territorio uma circulação que importa grandemente não só aos seus' nacionaes como a todos os povos: é tornar todos os navegadores victimas do formalismo, da intransigencia, da falta de intelligencia de um governo. Rejeitar n principio da soberania territorial é tornar todos. os habitantes da terra victimas do pouco caso ou da anarchia de um Estado que deixaria toda liberdade abusiva aos aviadores nacionaes. Admittir uma das theorias intermediarias, é abandonar todo principio e expor-se, segundo a interpretação diversa dos parlamentos, seja a um, seja a outra desses perigos.

E' preciso antes de tudo que os aviadores que atravessam as fronteiras com uma grande velocidade, possam ignorar a nacionalidade do solo que dominam, e que a locomoção internacional seja regulada por uma lei internacional. A natureza da atmosphera, homogenea e fluida, não susceptivel de divisão, incapaz de conservar a marca de uma occupação, nos leva a formular uma theoria completamente differente. - Os direitos dos homens sobre ella, ou dos seus agrupamentos nacionaes não podem exercer-se senão sobre sua totalidade. A posse dividida é tão 
inutil como impossivel. $\mathrm{O}$ ar é um, cada um terá delle a sua parte, si todos os possuirem inteiramente.

As diversas soberanias devem pois, coexistir no espaço total sem se acontoarem em qualquer de suas partes, o ar não podendo servir senão para uma circulação que deve levar para todos os logares sem se poder estacionar em nenhum.

Admittimos portanto que o ar não é res unius, nem res nullius, mas res communis, e que está em todas as suas partes submettido á soberania commum de todas as pessoas de Direito Internacional Publico. Estas estão a seu respeito na situação de indivisão forçada e perpetua dos condominos em communhão no Direito Privado. Não podem legislar a seu respeito senão de commum accordo e para todas as suas partes de uma só vẹz. Toda legislação emanando dum unico Estado não tem autoridade em logar nenhum nem sobre nenhum individuo. Toda modificação na legislação internacional no costume internacional não póde ser introduzida senão por um accórdo commum das potencias, sendo o statu quo a consequencia do veto de uma dellas. A atmosphera é dora avante a sahida universal para todos os pontos da terra; pode ser comparada a um rio internacional do qual todos os povos seriam ribeirinhos de uma unica vez. Esta theoria leva em conta de uma só vez a natureza da atmosphera, a necessidade de uma legislação commum, e a necessidade de uma legislação summaria, estavel e simples a qual estivesse livre de complicações borocraticas da parte das administrações devido a difficuldades das ententes internacionaes.

Os Estados alem do mais já admittiram esse principio acerca da radiotelegraphia cujas condições de livre exercicio foram reguladas por uma convenção internacional"

Não podemos considerar a doutrina de Ed. d'Hooghe, uma doutrina nova. Apenas proclama a liberdade dos ares, 
doutrina velha, e, acha, que ha necessidade de regular-se por uma legislação internacional uniforme a navegação aerea, coisa que ninguem poderá contestar.

Achamos absurda a liberdade dos ares, pelos motivos, que já demos.

Nem mesmo poderiamos, admittir a liberdade dos ares, com a restriç̧ão da tal zona de protecção.

\section{A theoria da Cadeira}

\section{Acceitamos a theoria da soberania territorial.}

Oppenheim, diz que seria vantajoso que os Estados em conferencia reconhecessem a soberania territorial do Estado sub-jacente e tambem, de outro lado, reconhecessem o direito para os Estados extrangeiros de pedirem que as aeronaves particulares unicamente, passagem pela sua atmosphera, desde que se submetessem ás suas leis. Mas limita o direito unicamente ás aeronaves particulares, e prohibe a passagem das publicas. Diz ainda Oppenheim, que a navegação aerea sobre o mar precisa de uma regulamentação especial devido aos perigos que offerece aos navios acontecendo o mesmo com a navegação em tempo de guerra. Portanto, para nós, a doutrina verdadeira é a da soberania territorial; a atmosphera não pode ser comparada ao mar; o Estado sendo o unico apto para dizer o que é vantajoso para a sua povoação, é livre de permittir ou prohibir a navegação sobre o seu territorio; seria vantajosa uma legislação uniforme sobre Direito Aereo.

E' essa a nossa doutrina sobre a materia. Estudaremos agora alguns pontos de Direito aereo, mas muito rapidamente. Sentimos apenas não poder fazer perante os Senhores um curso completo de Direito Internacional Privado Aereo. A materia toda de Direito Aereo é interes. 
santissima. Temos que applicar regras, principios de Direito a casos inteiramente novos .. Estudemos agora alguns aspectos da navegação aerea em tempo de paz ou de guerra.

\section{NAVEGAÇÃO AEREA EM TEMPO DE PAZ}

A primeira questão a discutir é a da nacionalidade da aeronave. Está claro que esta deve ter uma nacionalidade, como o navio. Tanto o vehiculo aereo como o navio desde que não tenham nacionalidade, são considerados piratas, não gozando portanto das garantias do Direito Internacional.

Até mesmo o automovel tem a sua nacionalidade.

(Conv. intern. 11 de Outubro de 1909).

Mas quando se trata de saber qual a lei que determinará a nacionalidade da aeronave surgem as difficuldades. Uns dizem que esta será determinada pela nacionalidade do proprietario. (Congs. Paris, art. $3 .^{\circ}$ ).

Outros, determinam a nacionalidade pelo logar da matricula (Inst. Direito Internacional).

Da diversidade das leis podem surgir conflictos, que serão estudados em Direito Internacional Privado.

O mesmo acontece quanto ao domicilio. Toda aeronave deve ter o seu domicilio.

Qual será elle?

O da matricula, ou o do seu proprietario? As opiniōes divergem.

Qual será o signal distinctivo da nacionalidade da aeronave? Outra questão interessante. São questões bellissimas e novas que cabem melhor em Direito Internacional Privado. Devemos observar ainda que as aeronaves, do mesmo modo que os navios, devem ter papeis de bordo.

$\mathrm{O}$ navio soffre avarias, a aeronave tambem. 
$\mathrm{H}_{\mathrm{a}}$ ainda as questões referentes á "atterrissage" e ao naufragio. Apenas fazemos a indicação rapida dessas questões que os Senhores estudarão mais tarde.

\section{COMMUNiCAÇões AEREAS}

A guerra de 1914 a 1918 demonstrou os horrores do emprego de aeronaves na guerra; mas durante a paz, ainda não ficou demonstrado que possam ellas prestar relevantes serviços ao commercio mundial. Comtudo os Estados signatarios da Conv. de Paris de 1919, regulando à navegação aerea, proclamaram no preambulo o desejo de favorecer o desenvolvimento das communicaçōes aereas internacionaes com um fim pacifico. Reconheceram tambem a doutrina da soberania territorial (Société des Nations, Recueil des traités t. VI).

Passaremos a estudar o uso das aeronaves na guerra

A guerra aerea é novississima. Mas o uso de balões captivos já não é tão novo. Logo que se descobriu o uso dos balöes os homens pensaram immediatamente em empregal-os para destruir o seu semelhante.

Mas, sem direçãa alguma, os balões de pouca utilidade eram nas operaçöes militares. Os balóes captivos foram empregados comtudo nas guerras da revolução francesa, parece que com algum successo. Os francezes recordarão sempre o papel brilhante do "L'Entrepenant, em Fleurus, dirigido por Coutelle"

Mas, Napoleão, o grandel adepto da artilharia, nunca teve grande confiança na guerra aerea. Comquanto durante o seu governo tivessem apparecido planos de invasão da Inglaterra por meio de aeroplano, elle nunca, ao que pareceu os levou a serio.

Abandonados por Napoleão, somente em 1870 foram os balóes usados novamente nas guerras. 
- $\quad$ facto notavel deste emprego dos balóes em 1870 foi o vôo de Gambetta. Mas ainda não se póde fallar em uma guerra aerea.

Depois de 1870 começou-se a estudar seriamente o empregó dos balóes na guerra e o problema da dirigibilidade.

Foram empregados na guerra do Paraguay, na campanha do Transvaal, da Abyssinia e na guerra hispano Americana.

Descoberto o balão pelo brasileiro Bartholomeu de Gusmão, a outro brasileiro Santos Dumont, estava reservado a descoberta da dirigibilidade dos balóes. Mas, apesar dos progressos da aviação, dos trabalhos de Zeppelin, Santos Dumont e outros, os dirigiveis só foram applicados na guerra italo-turca.

Antes dessa campanha não se pode fallar propriamente em guerra aerea.

\section{Declaração de Haya}

Em declaração de 29 de Junho de 1899 a: conferencia de Haya adoptou o seguinte: "Les puissance contractantes consentent, pour une durée de cinq ans à l'interdiction de lancer des projectiles et des explosifs du haut des ballons ou par d'autres modes analogues nouveaux" Esta declaração foi acceita sem reluctancia, porque não estava em jogo ainda o interesse dos Estados.

\section{NA $2 .^{a}$ CONFERENCIA}

Em, 1907, na 2. ${ }^{\text {a }}$ conferencia, o principio proclamado na 1.* conferencia teve adversarios terriveis. Já a aviação havia progredido muito e o interesse dos Estados que possuiam aeronave de guerra era empregal-as para destruir os seus adversarios. Entre os defensores da guerra aerea 
apontemos o grande Renault. Depois de muitas peripecias, a Allemanha, a França e a Russia voltaram contra a interdicção. $O$ Japão se absteve e com razão, pois não sendo a approvação unanime não tinha valor pratico nenhum.

Como diz Oppenheim esta prohibição não seria acceita certamente na terceira conferencia.

\section{O INSTITUTO}

Alem das conferencias de Haya, o Instituto de Di. reito Internacional occupou-se longamente com o uso das aeronaves. Na sessão de 1900 (Neufchatel) P. Fauchile e $N y s$ apresentam as suas conclusões e na sessão de 1911 (Madrid), volta o Instituto a tratar da materia.

$\boldsymbol{P}$. Fauchile defende a legitimidade da guerra aerea, Von Bar, Westlake e Rolland a condemnam.

A assemblea vacillou muitissimas vezes e depois dos mais comicos incidentos acceitou e rejeitou o contra projecto Von Bar, e finalmente foi approvada a formula LapradeIle Nercier: "La guerre aérienne est permise, mais à la condition de ne pas présenter pour les personnes ou la proprieté de la population pacifique de plus hauts dangers que la guerre terrestre ou maritime"

Mas a verdade é que os paizes europeus queriam empregar as aeronaves na guerra e as empregaram amplamente bem como os submarinos para destruir as forças dos adversarios.

E' Licito O USO DE AERONAVES NA GUERRA?

Pergunta-se, é licito o uso de aeronaves na guerra?

A resposta é a mesma que demos á these é licito o uso de submarinos na guerra? (Vide Revista da Faculdade...)

Como não se pode fallar em usos e costumes internacionaes acerca de armas novas como o submarino e os 
dirigiveis, não sendo estes prohibidos nem por tratados nem pelos costumes tendo sido empregados nas ultimas guerras, podemos responder em face dos principios do Direito Internacional que os aeronaves de guerra podem ser amplamente empregados.

Isto quanto ao que está constituido. Comtudo seria vantajoso que os Estados se unissem para abolir a guerra aerea, que, como a submarina, vem marcar um retrocesso na evolução das leis da guerra, tendentes a tornal-a cada vez mais humana e menos cruel.

A guerra submarina e a aerea, conforme se verificou na conflagração Européa, vieram tornar a guerra mais sangrenta e prejudicar grandemente o interesse dos neutros. Provisoriamente, emquanto nada ha de constituido sobre a guerra aerea e submarina, devem a ellas ser applicadas as mesmas regras de guerras terrestres e maritimas.

Assim os allemães violaram conscientemente, os principios de Direito Internacional quando atacaram cidades da França por meio de bombardeamento aereo, destruindo monumentos, hospitaes, casas de cidadãos inermes. As crueldades dos barbaros só pode ser comparada á de seus dignos alliados, os austriacos, no cerco de Veneza, em 1849.

Tambem cruel e absurda é a these allemã, do feroz Bismark, de que os aeronautas deveriam ser tratados como espiões (Nota de 19 de Novembro de 1870), e sustentada por Geffcken Heffter, Lueder Holtzendorf - v. IV, pag. 461, Bruntschli, etc. A these allemã foi condemnada pela Decl. de Bruxelles (1874), pelas Conferencias de Haya, por todos os escriptores civilizados, que proclamam que os aeronautas devem, quando capturados, ser tratados como soldados empregados em operações licitas e guerra (Davis, pag. 299, Snow, pag. 91, Hall, Risley, Phillimore, etc.). 


\section{FONTES}

1 - Holzendorf, II pag. $230-2$ Bonfils, ns. 231 - 231? = 3 Despagnet n. 433 bis -4 Nys, 1. pag. 523 - 5 Mérignhac 2. ${ }^{\circ}$ pag. 398 - 6 Magnani, - Il diritto sullo spazio aereo. - 7 Leech - Jurisprudence. - 8 Edouard d'Hooghe - Droit Aérien. - 9 Licklama Nijeholt - Air. - 10 Catallani - Diritto Aereo. - 11 Bevilaqua 1.c pag. 333. - 12 Blewett Leeo - Sovereignty of the Air. - 13 Hollander. - 14 Meili. — 15 Meyer. - 16 Meurer. - 18 Loubeyre. - 19 Thibaut. - 20 Bellenger. - 21 Richards. - 22 Hazeltine. — 23 Spaight. Muitas outras obras interessantes foram escriptas sobre a materia.

Temos assim estudado resumidamente o nosso ponto.

PONTO $15 .^{\circ}$

\section{SERVIDÕES INTERNACIONAES}

Noção: - "Servidões internacionaes são restricções excepcionaes e convencionaes na supremacia territorial de um Estado em virtude das quaes todo ou parte do seu territorio fica, de uma maneira limitada, servindo perpétuamente certos interesses de um outro Estado", ensina Oppenheim.

Alguns atacam rudemente a doutrina das servidóes internacionaes, (Corte Permanente de Arbitragem de Haya, caso Norti Atlantic Coast Fisheries). Mas estes ataques não têm razão de ser. 
E' bom não confundir como fazem alguns (Hall, Nys) as restricções applicadas a todos os Estados, por exemplo, a obrigação de não impedir a passagem de navios mercantes pelas suas aguas (servitutes juris gentium naturales), com as restricções convencionaes, applicadas ao territorio de um Estado (servitutes juris gentium voluntariae)

SuJeito das SERVidões.

Sendo o Estado a unica pessoa de Direito Internacional, só elle póde ter servidões admissiveis unicamente entre Estados (territorium dominans e territoriuns serviens).

\section{Овјесто}

Pode ser objecto de servidão todo o territorio ou parte delle. Quando dizemos, territorio referimo-nos á terra, ás aguas e ao espaço aereo.

\section{Divisão •}

As servidões são:

1. ) Affirmativas, activas ou positivas.

$2^{\circ}$ ) Negativas.

$\left.3 .^{\circ}\right)$ Militares.

$\left.4 .^{\circ}\right)$ Economicas.

\section{VALIDADE}

As servidões, não sendo direitos pessoaes (jus in personam) mas sim direitos inherentes ao objecto (jus in rem), conservam-se validas, sejam quaes forem as mudanças operadas nos Estados. 


\section{ExtincÇão}

Extinguem-se as servidões:

1.') pelo accordo entre os dois Estados;

$\left.2 .^{\circ}\right)$ pela renuncia por parte do Estado em proveito do qual foi creada a servidão, ou pelo não uso, por uma geração;

$3 .^{\circ}$ ) quando os dois Estados se unem formando um unico Estado.

FONTES: - Bevilaqua, I $\S 83-2$. Foignet -3 . Moore, I $\oint 163$ e II $\oint 177-4$. Bonfils, $n *^{\circ} 340$. -5 . Despagnet, n. ${ }^{\circ}$ 190. - 6. Mérignhac, II, pag. 366. - 7 . Davis, pag. 68. - 8. Lafayette, 1 pag. 162. - 9. Phillimore, I $\oint 281$. - 10. Taylor, $\S 252$. - 11. Calvo, III $\S$ 1583. - 12. Nys, II, pag. 271. - 13. Rivier, 1 pag. 296. - 14. Ulmann, § 99. - 15. Westlake, I pag. 61. - 16. Twiss, I $\S 245$. - 17 Fiore, I $\$ 380$ e Codigo - 1095-7.

$$
\text { "PONTO } 16^{\circ}
$$

Modos DE ADQUiRIR E PERDER O TERRITORIO

Não existe entre os autores de Direito Internacional unanimidade sobre os modos de adquirir o territorio.

Isto por ter variado o conceito de territorio do Estado, depois do apparecimento do Direito das Gentes.

\section{Doutrina do Estado Patrimonial}

Dominou a principio, logo que Grotio fundou o Direito Internacional, a doutrina que confundia o territorio do Estado com a propriedade privada do Monarcha. 
Applicavam-se portanto aos modos de adquirir o territorio as regras do Direito Romano (Grocio, II cap. $3 \S 4$ - V I. Westlake, Chapt. e Int. Law).

Hojeı a Doutrina do Estado patrimonial está morta.

A acquisição do territorio nada mais significa modernamente que a acquisiçẫo da soberania sobre esse territorio.

Por isso hoje não se applicam as regras romanas, sinão em termos mui restrictos.

Tratando-se da acquisição do territorio pergunta-se em 1. ${ }^{\circ}$ logar: quem pode adquirir o territorio do Estado?

Somente os Estados podem adquirir o territorio, por. que são os unicos sujeitos do Direito Internacional.

As regras sobre os modos de adquirir e perder o territorio são magnificamente expostas por Epitacio Pessoa, no seu monumental Codigo.

\section{Artigo 36.}

A soberania territorial pode adquirir-se por occupação, accessão, usocapião, cessão gratuita, troca ou venda.

Artigo 37.

Para que a occupaçãa seja legitima é necessario: Estado;

a) que recáia em territorio não pertencente a outro

b) que seja real e effectiva e seguida de actos que revelem claramente da parte do Estado occupante o animo de se apossar do territorio como soberano; e

c) que o occupante notifique o seu acto por via diplomatica aos demais Estados, com a determinação, tĩo exacta quanto possivel, dos limites do territorio occupado. 
Em nota observa o illustre internacionalista que a acquisição da soberania por occupação só pode ter logar em terras por descobrir, em terras polares por exemplo.

No artigo 41, reconhece Epitacio o usocapião como modo de adquirir territorio desde que resulte da posse de boa fé, notoria, pacifica e continua, pelo espaço de 40 annos.

Uns, como Liszt e Clovis, não admittem usocapião em Direito Internacional; outros, como Epitacio, Hall, etc. reconhecem o usocapião como meio legitimo de adquirir territorio, e é essa a opinião dominante na materia.

\section{Artigo 44.}

O Estado perde a soberania territorial por prescripção, cessão onerosa ou gratuita ou desapparecimento do territorio." Temos ainda um meio de perder o territorio - a revolta.

Assim, a Belgica abandonou a Hollanda em 1830; os Estados Unidos, a Inglaterra, em 1776; o Brasil, Portugal, em 1882; Cuba, a Hespanha, 1898; etc.

Quando se consuma a perda do territorio pela revolta, é uma questão de facto.

Não se pode dar uma regra geral e perfeita, porque tudo depende do caso especial.

FONTES: - Hall, $\S 31$ - Bonfils 532, - Despagnet, 378 - Oppenheim, 1 pag. 281 - Nys, II pr. Phillimore, l $\S$ pag. 222-5-284-295. - Moore $1 \oint \oint 89$ e 90 - Fiore II n. ${ }^{\circ} 865$. - Bevilaqua, Epitacio, Lafayette. 


\section{$-125-i$}

PONTO $17 .^{\circ}$

\section{O MAR. LIBERDADE DOS MARES.}

"Alto mar é a parte corrente de agua salgada sobre grande parte do globo, com excepção do mar territorial, dos estreitos, golfos e bahias, que fazem parte do mar mas não do oceano" (Oppenheim).

\section{O MAR TERRITORIAL}

Sobre a extensão do mar territorial muito se tem discutido.

Deixando de parte a maxima de Bynkershoeck, "terrae patestas finitur ubi finitur armorum vis", seguida pori tantos escriptores, muita divergencia ha sobre o assumpto. Twiss, Wheaton, adoptam a extensão de 3 milhas, Westlake, 5, Field, 3, Lapradelle é arbitrario, e distingue o caso da pesca, da neutralidade e da policia, aduaneira ou sanitaria.

Epitacio diz que parece acertado o limite do mar territorial de 6 milhas.

\section{O ALto MAR}

O mar alto é livre, e, não pode estar sujeito á soberania de nenhum Estado.

Comtudo, apesar de livre o mar alto não está fora de toda lei. Está submettido a varios principios o seu uso pelos povos.

Muitas' regras estão admittidas universalmente. Tanto em tempo de paz como de guerra ha bastantes regras sobre o uso do alto mar. Qualquer de sua parte, por exemplo, pode ser neutralizada em tempa de guerra. 


\section{A Liberdade dos mares}

Comquanto a liberdade dos mares seja um principio geralmente acceito, nem sempre assim foi.

Segundo vemos nos textos de Ulpiano e de Celso, citados pelos internacionalistas, o mar alto era livre na Antiguidade e assim continuou na $10^{a}$ metade da Edade Media.

Pouco importa a platónica pretensão de alguns imperadores proclamando-se pomposamente - reis do oceano.

Só na 2. ${ }^{a}$ metade da Edade Media, com o desenvolvimento do commercio, começaram os povos a disputar a soberania dos mares.

Veneza queria ser soberana do Adriatico; Portugal, do mar das Indias; a Espanha, do Pacifico, etc. -

Grocro: - Apesar de não ser o $1 .^{\circ}$ a tratar da materia - (Nys, Les Origines), foi Grocio, o maior defensor da liberdade dos mares.

Mare Liberum (1609) 0 principal desejo de Grocio era combater as iniquas pretensões dos portuguezes, que, descobrindo o caminho do Cabo de Boa Esperança, não queriam que a sua passagem aproveitasse aos outros povos.

Segundo o Direito das Gentes, ensina Grocio, a navegação é livre a todos (Jure Gentium quibus visant quovis liberam esse navigationem).

No capitulo que, trata das coisas communs a todos, diz que o ar deve ser livre (Ilujus genere est aer, duplice ratione trium qui a occupari non potest, tum quia usum promiscuum hominibus debet); e assim tambem o mar: Contra Grocio appareceram varios escriptos, dos quaes o mais notavel é o de John Selden "Mare clausum sive de dominio mare" em 1618, publicado em 1835. O livro do grande jurisconsulto é o que ha de mais absurdo. Nada mais é que o amontoado de uma erudição formidavel e indigesta. Vae procurar as suas provas em Noé, nos $\mathrm{Nu}$ meros, nas Profecias de Ezequiel, no reino de Neptuno, etc. 


\section{TRIUMPHO DO PRINCIPIO}

Mas o triumpho das ideas de Grocio foi lento porque encontrou muita opposição no seu tempo. Em dois motivos fundava elles razão da liberdade dos mares: mente;

$\left.1 .^{\circ}\right)$ porque o mar não pode ser occupado efficaz-

$\left.2 .^{\circ}\right) \quad$ porque repugna á natureza a occupação de uma coisa que é inutil a todos e por todos pode ser usada sem damno para ninguem. -

\section{RAZÃo dA LIBERDADE DOS' MARES}

Os dois motivos nada valem actualmente. A razão é a seguinte: - o mar é uma grande estrada que liga os povos, e é portanto de interesse de todos os povos que nenhum o possua em uma de suas partes.

E' no interesse do livre intercurso entre os povos, reconhecido pelo consentimento commum que repousa 0 motivo da liberdade dos mares.

FONTES: - Grocio, II C. $2 \S 3 .-2$. Bonfils, 573 e seguintes. - 3. Mérignhac, II, pag. 498. - 4. Ortolan, Diplomatie de la mer. - 5. Nys, II pag. 14 a "Les Origines" - 6. Hall, $\S 40-7$. Oppenheim, 1 pag. 315. 
Ponto 18.

\section{JURISDICÇÃO NO MAR - PIRATARIA}

No mar não ha anarchia. A navegação tem que se submetter a certas regras universalmente reconhecidas. $\mathrm{Ha}$ no alto mar uma harmonia perfeita das regras de Direito Internacional e Direito Privado, para conseguir-se a navegação inoffensiva delle. Mas é preciso notar que a jurisdicção não é sobre o alto mar, mas sim, sobre navios, pessoaes e coisas navegando no alto mar.

Os navios de guerra têm certos direitos sobre os na. vios mercantes de todas as nações, como veremos melhor mais tarde.

Todo navio que pretende gosar das vantagens do Direito Intemacional precisa usar uma bandeira, pois pela bandeira e pelos papeis de bondo conhece-se a sua nacionalidade. Mesmo o Estado encravado pode possuir navios mercantes, comtanto que estes tenham um pavilhão. (E $\boldsymbol{p} i$ tacio Cod. art. 229).

Os navios devem ter papeis de bordo, mas estes são determinados pelo Direito interno de cada Estado. Cada Estado exige um certo numero de papeis de bordo ( $\mathrm{Hol}$ land, Manual of Naval Prize Law).

Os mais communs são:

$\left.1 .^{\circ}\right)$ os documentos relativos á propriedade e identidade do navio;

2. ) o conhecimento;

$\left.3 .^{\circ}\right)$ o rol da equipagem (the muster roll);

$\left.4 .^{\circ}\right)$ o diario de bordo. (Epitacio, Cod. $227 \oint 2 .^{\circ}$ ). Os inglezes falliam nos seguintes:

$\left.1 .^{\circ}\right)$ The muster roll; $2 .^{\circ}$ ) The Log Boock; $3 .^{\circ}$ ) The manifest of cargo; $4 .^{\circ}$ ) The Bill of lading; $5 .^{\circ}$ ) The Charter Party; $6 .^{\circ}$ ) An official vaucher autorising the vessel to sail under its flag. Passport, sea-letter, soa- 
brief etc, para determinar a nacionalidade do navio. Todo navio precisa ter, alem do mais, um nome (Epitacio, cod. 230, Sect. 50 and. 53 of the Merchant Shipping Acts, 1906).

Os navios mercantes, em alto mar, são considerados porções fluctuantes do territorio nacional (Halleck, Davis, Grotio, Ortolan. Oppenheim combate esta theoria, argumentando com excepções).

Pirataria: “E' qualquer acto de violencia, não autorizado, contra pessoas ou bens feito no mar alto, seja por um navio particular, seja pela tripulação revoltada contra o seu proprio navio" (Oppenheim).

O pirata é considerado um "hostis humani generis" e a pirataria, um crime internacional.

Qualquer navio pode punir os piratas, onde forem enicontrados, e de morte (Davis, Int. Law pag. 61). Os navios com carta de marca, não são piratas. Nem os navios de guerra podem ser considerados piratas, salvo quando revoltando-se contra o seu paiz, cruzam os mares por conta propria, deixando no caso de ser navio publico.

Maiores particularidades os allumnos aprenderão mais tarde:

Fontes: - 1 . Hall, $\$ \oint 45$ e $81-2$. Taylor, $\oint \oint 262$ e 188 - 3. Despagnet, n. $422-4$. Bonfils, $2-578$ e 592 - 4. - 5. Merignhac, II, pag. 536 - 6. Westlake, I, pag. 181.

\section{Ponto 19.}

\section{O FUNDO DO MAR E o DIREITO INTERNACIONAL}

0 fundo do mar merece especial attenção ein Dineito Internacional devido aos tunneis, ás riquezas submarinas e ás minas, principalmente de carvão. 
Mas, a quem pertencerá o fundo do mar?

Quanto ao mar territorial pertence evidentemente ao Estado que elle banha, havendo apenas discussões sobre a sua maior ou menor extensão. Em relação ao fundo do mar porem a questão compllica-se singularmente. Diz o eminente Oppenheim (Int. Law, I p. 751) que não existe para a liberdade do fundo do mar alto a mesma razão que para a liberdade dos mares, isto é, ser uma estrada indispensavel que liga os continentes, podendo pois perfeitamente conceber-se a occupação do sub-solo do oceano.

\section{AS REGRAS DE OPPENHEIM}

Formúla Oppenheim as seguintes regras sobre o assumpto:

1 - O sub-solo embaixo do fundo ido mar é territorio que não pertence a ninguem, e póde ser occupado pelo Estadó littoral por uma occupação que parta do subsolo da faixa do mar territorial.

2 - Esta occupação tem logar ipso-fiacto por um tunnell ou uma mina começada no sub-solo da praia da costa e prolongando-se pelo sub-solo do mar a dentro.

3 - A occupação do sub-solo do alto mar pode extender-se até a linha da faixa ido mar territorial de um outro Estado, porque nenhum Estado tem o exclusivo direito de occupar o sub-solo do alto mar por ser adjacente ao subsolo do seu mar territorial.

4. - Uma occupação do sub-solo abaixo do leito do allto mar para um fim que ponha em perigo a liberdade do mar alto é inadmissivel.

5. - E' tambem inadmissivel fazer no sub-solo debaixo do alto mar, previamente occupado para um fim legitimo, arranjos que indirectamente ponham em perigo a liberdade do mar alto.

Acceitamos estas regras. 


\section{TUNNEIS}

Quanto aos tunneis ligando duas partes de um mesmo Estado e passando pelo sub-solo do alto mar, não ha discussão: - pertencem ao Estado cujas partes foram por elle ligadas. Seria o caso de um tunnel ligando a Escossia e a Irlanda.

Qual a solução no caso de um tunnel ligando territorios de Estados differentes e passando pelo fundo do mar?

A quem pertencerá por exemplo, o projectado tunnel de Gibraltar?

Os tunneis de Gibraltar e da Mancha

Diz Oppenheim que arranjos deverão ser feitos para, por tratado, regular a posição intemacional da parte que fica sob o fundo do mar no caso de tunneis entre dois Estados: Gibraltar ou Canal da Mancha.

Trabalhos vários foram feitos para construir-se o tunnel sob o canal da Mancha, entre Douvres e Calais. Comquanto já antes de 1870 se idiscutisse a possibilidade desse tuninel só depois de 1874 é que foram começàdos os trabalhos preliminares: - exploração geologica do sub-solo do canal, tentativa partindo da face ingleza, etc.

Em 1876 uma commissão dos governos inglez e francez apresentou um relatorio que deveria servir de base para o trabalho.

Comtudo tudo deu em nada, porque a opinião publica ingleza era contrária á construcção do canal. O mesmo aconteceu com os successivios tentamens de 1880, 1884, 1888, 1908 e 1911.

Depois da grande guerra, parece que ha um movimento definitivamente favoravel á construcção do tunnel, sob o canal da Mancha.

\section{POSIÇÃO INTERNACIONAL}

Acho que aos tunneis sub-marinos ligando Estados differentes devem se applicar os principios do oondominio. 


\section{RIQUEZAS SUBMERSAS NO PÉGO}

A quem pertencerão os bens submersos no fundo do mar, p. ex., os galeões hespanhoes carnegados de riquezas, naufragados ha tantos annos?

A resposta não é facil.

Quanto ás riquezas que se acham submersas no mar territorial de um Estado a sua posição é regulada pelo Direito interno desse Estado. Mas como se resolverá o caso no alto mar?

\section{Os TEXTOS ROMANOS}

Lê-se no Dig. (lib. XLI tit. II l. XIII): — "Refere Pomponio que se afundaram umas pedras no rio, por naufragio e se extrairam depois de algum tempo: reteve-se acaso o dominio durante o tempo em que estiveram submersas? Julgo que sim, mas não se reteve a posse"

No Dig. (lib. XLI tit. II 1. XXI), ensina Javoleno: "O que se deixou no mar por causa de naufragio, e o mar arrojou para fóra, não se póde usocapir, porque não se deixou com intençáa de perder o dominio, comquanto se deixasse por pendido. $\mathrm{O}$ mesmo se diz do que se lançou ao mar, pois não parece que se deixou com intenção de perder o dominio, e sim para salvar a vida".

O Dig. no mesmo llivro e titulo (l. VIII), diz: "Assim como não se póde adquirir nenhuma especie ide posse sem tomar a coisa com intenção de possuil-a, do mesmo modo não se póde perder nenhuma especie de posse sem deixar a coisa com intenção de não a possuir" (Paulo).

\section{A licção de Pothier}

No lib. XLI tit. I n..$^{\circ}$ XCVII ensina a Pothier (Pandectas), após advertir que se perde o dominio da coisa que se abandona, que o mesmo não acontece icom as coisas que se atiram ao mar, afim de alliviar o navio do seu peso. 
"Na verdade estas pertencem sempre ao mesmo proprietario, porque se atiram ao mar não com a intenção de se ficar privado dellas, mas sim para com a nave salvar-se a propria vida dos perigos do mar. Donde si alguem se apodera dellas, quando transportadas pelo fluxo das ondas á praia, ou quando as encontra no proprio mar, commette furto"

E continúa: "Do mesmo modo para Paulo: - a coisa atirada ao mar fica sempne do proprietario; e não se torna daquelle que'a encontra, porque não se considera como abandonada. Tambem Javoleno: a coisa extraida d'o mar não se torna de quem a extraiu, antes que o proprietario a considere como abandonada"

\section{ConClusão}

As riquezas submersas no pégo continuam a pertencer aos seus primitivos donos, que perderam a posse, mas não o dominio.

\section{PESCARIAS}

As pescarias nas costas, no mar territorial, são reguladas pelo Direito interno dos Estados, pois, como é sabido, a jurisdicção do Estado se extende ao mar territorial (Davis, p. 61; Calvo, § 932; Oppenheim, p. 441 vol. I.).

Como consequencia da liberdade idos mares a pesca é livre no alto mar a todas as nações (Davis, p. 60; Phillimore, p. 211; Oppenheim, f. p. 441; Epitacio, Cod. art. 261).

\section{COMMUNICAÇÕES SUBMARINAS}

Os Estados têm o direito de pôr no alto mar telegraphos e telephones.

Estes meios de communicação devem evidentemente ser protegidos, e foi porisso que, em 1869, os Estados Unidos propuzeram uma convenção para esse fim que fracassou em consequencia da guerra franco-prussiano. 
Em 1876 o Instituto de Direito Internacional tratou da materia, e recommendou um accordo internacional. Em 1884 é assignada em Pariz uma convenção para protecção dos cabos submarinos.

Baseado nessa convenção formulou Epitacio o art. 275 do seu magnifico codigo: - "Os Estados protegerão por meio de leis adequadas os cabos telegraphicos immersos no allto mar ou nas suas aguas territoriaes e, sem prejuizo da acção civil, punirão quaesquer infracções dessas leis e especialmente o cónte ou deterioração dos cabos, praticados dolosamente ou por negligencia culposa e de que possa provir interrupção ou impedimento total ou parcial das communicações telegraphicas" Quanto aos telegraphos sem fio, reuniu-se uma conferencia em Berlim (1906), da qual resultaram duas convenções (Martens, Nouveau Recueil Générall du Traités, $3 .^{a}$ ser., III p. 147).

Outra conferencia reuniu-se em Londres, com melhores resultados.

Fontes: Oppenheim, vol. 1, pgs. 451, 441 (Pescarias) e 446-451 - Davis, 57, 60, 61 e 645585 Epitacio, Cod. pgs. 108, 109 e 112.

\section{Ponto $20 .^{\circ}$}

\section{O INDIVIDUO E O DIREITO INTERNACIONAL. NACIONALIDADE E NATURALIZAÇÃO.}

$\mathrm{O}$ individuo é muito importante em D. I. Não é nunca sujeito, é objecto. $\mathrm{O}$ vinculo que liga o individuo ao D. I. é a nacionalidade. "Nationality of an individual is his quality of being a subject of a certain State, and therefore its citizen" (Oppenheim, v. I. p. 463) Segundo Clovis (v. 1, p. 261, § 49), a nacionalidade é um vineulo politico e pessoal, que liga o individuo a determinado paiz, sua patria de origem ou de adopção, tornando-o parte integrante do povo desse paiz, submettendo-o á autoridade e á protecção da soberania, que nelle impera. 
Adquire-se geralmente a nacionalidade: 1) pelo logar do nascimento (principio territorial, "jure soli" 2) pela filiação (principio pessoal, "jure sanguinis"; 3) pela naturalização; 4) e, collectivamente, pela incorporação ou annexação de Estado extrangeiro ou de parte de seu territorio. No Brasil (Arts. 69 e 71), perde-se a nacionalidade por varias formas: pela naturalizaç̧ão em paiz extrangeiro, pelo casamento, etc. Emfim, as condições, mediante as quaes se adquire e perde a nacionalidade regulam-se pelo Direito interno de cada paiz.

Fontes: Oppenheim, v. 1, p. 463 - Despagnet, 329 - Calvo, v. II, 539 - Bonfils-Fauchille, v. 1, p. 841, n. 417 e seguintes.

\section{Ponto 21.}

\section{EXTRADIÇÃO}

"L'extradition est l'acte par lequel 'un Etat livre un accusé ou un condamné qui s'est refugié sur son territoire à un autre E'tat, pour lui permettre de le faire juger par ses tribunaux ou de lui faire subir sa peine" (Foignet) "Extradition is the delivery of a prosecuted individual to the State on whose territory he has commited a crime by the State on whose territory the criminal is for the time staying" (Oppenheim) A extradição não é obrigatoria em D. I. Não existe uma obrigação de extraditar criminosos, mas, pelo contrario, ha o direito de asylo. Grocio e Clarke entendem ser a extradição obrigatoria.

Evolução. Antes do seculo 18 extraditavam-se sómente os criminosos politicos. Paulatinamente é que se foram extraditando os outros criminosos, e se estabeleceu o principio da não extradição de criminosos politicos. No seculo 19 é que começou a surgir a noṿa doutrina da extradição de criminosos não politicos. 
O PRINCIPIO DÉ NÃO EXTRADIÇÃO DE CRIMINOSOS POLiticos surgiu com a revolução franceza. Art. 120 da Const. franc. de 1793. Inglaterra. Depois da Const. franc. de 1793 foi Sir James Mackintosh, em 1815, na Inglaterra, o $1 .^{\circ}$ a defender o principiọ da não extradição de criminosos politicos. Logo depois, em 1816, um outro lord inglez, Lord Clartereagh, defende tambem o principio. Depois vem a Suissa. Em 1830 começa uma reacção. A Austria e a Prussia se recusam a extraditar os criminosos politicos polacos. 1829 Provó Kluit. "De Deditione Profugorum" E' o 1. a sustentar o principio com argumentos juridicos. Houve reacção em 1833 contra o principio. Nova Santa Alliança: Austria, Prussia e Russia. Triumpho do principio. 1833 - Lei Belga. Concepção: Crime politico é o que é commettido tendo um fim politico; por um motivo politico; ou, por ambos ao mesmo tempo. Ha delictos complexos. Os numerosos attentados contra a vida dos chefes de Estado trouxeram reaç̧ão contra o principio. (Assassinatos depois de 1850: 1) Carlos III, Duque de Parma - 26 de Março de 1854; 2) Principe Danilo do Montenegro - 14 Ag. 1860; 3) Lincoln - 14 de Abril 1865; 4) Principe Miguel (Servia) 10 Junho 1868; 5) Presidente Balda do Perú — 26 Julho 1872;6) Presid. Garcia Moreno (Eq.) — 14 Ag. 1872; 7) Sultão Abdul Aziz (Turquia) - 4 Junho 1876; 8) Alexandre II (Russia); 13 Março 1881; 9) Pr, Garfield (Amer. do Norte) 2 Julho 1881 ; 10) Carnot - 24. Junho 1894; 11) Toxá da Persia - 1 de Maio 1896; 12) Imp. Isabel da Austria - 1.0 set. 1901; 13) Rei Humberto I - 29 รัulho 1900 ; 14) Mac-Kinley -6 set. 1901; 15) Alexandre da Servia e a Rainha Draga - 11 Junho 1903; 16) D. Carlos de Port. - 15 Fev. 1908; 17) Caceres (S. Domingos) - 19 nov. 1911; 18) Rei George da Grecia 18 de Março 1913; 19) Arr. Fco. Fernando e sua consorte - 28 Junho 1914; 20) Pres. Sid. Paes de Port. 15-12. 1918; 21) Pres. Carranza (Mexico) - Maio 1920. Deve 
continuar o principio. O tyranicidio é condemnavel mas é, geralmente um producto da oppressão. Caso do Massilia, 27-12-925. Qual o crime? Leis imaginarias. Caso da extradição do Kaiser-Trib. parcial.

O Extrangeiro. Expulsão. O Estado não é obrigado a admittir o extrangeiro no seu territorio; comquanto se opponha á isto Bluntschli. O Estado tem o direito de defeza de sua raça. Comtudo, o Estado que cortasse toda a entrada de, extrangeiros, viria ferir os interesses da communhão social.

A questão do asylo. Todo o Estado tem o direuo de asylar extrangeiros, comtanto que, esse asylo não seja prejudicial ao Paiz. Não póde um Estado, em caso de guerra expulsar todos os subditos do paiz extrangeiro. 0 decreto 164.1 de 7 de Jan. de 1907 regula a expulsão.

Ponto $22 .^{\circ}$

\section{CHEFES DE ESTADO. MINISTERIO DAS RELAÇÕES EXTERIORES}

"Chefe de Estado é a pessoa á qual é confiada a direcção suprema dos interesses geraes do Estado" Sendo o Estado composto de uma multidão de individuos, é indispensavel que tenha um chefe de Estado, seja de que especie fôr. A'o Direito Internacional pouco importa que o chefe do Estado seja monarcha, presidente, ou qualquer outro, é necessario apenas que elle exista. Em regra quando sobe ao governo um novo chefe do Estado, o facto é levado ao conhecimento dos outros povos, que o reconhecem, por congratulações, por exemplo. Este reconhecimento não é obrigatorio, mas tem importancia, porque, sendo negado, é impossivel qualquer relação entre os dois paizes. Os actos mais importantes do chefe do Estado, são considerados actos do proprio Estado ("jus representationis omnimodi"). Os chefes de Estado, contrariamente ao 
que querem Heffter e Phillimiore são objecto, e não sujeitos de D. Internacional. O\& seus privilegios são devidos aos direitos e deveres do Estado, e não thes são concedidos como pessoas. Como ha differença entre monarchas e presidentes, sendo os primeiros soberanos, o D. I. os trata differentemente. O monarcha é, pelo D. I. das monarchias, um soberano. Porisso são todos os monarchas eguaes, e assim tratados pelo D. Internacional. Devem ser tratados em todos os seus titulos. Têm direito ao ceremonial e honras e á inviolabilidade individual, porque a sua pessoa é sacrosanta; e finalmente têm a exterritorialidade, de conformidade com o principio "Par in parem non habet imperium" Alguns dizem que a exterritorialidade não se extende ao sequito do monarcha. Penso, com Epitacio e Oppenheim, que as pessoas do sequito do monarcha têm tambem o gozo das immunidades, pois, como muito bem pondera Oppenheim, não seria razoavel que o sequito de um monarcha tivesse menos privilegios que os de um simples agente diplomatico. Os chefes de Estado que viajarem incognitos não terão direito á immunidade alguma, salvo levantando o incognito. As sim o Rei Guilherme da Hollanda, em 1873, levantou o incognito na Suissa, para passar um calote! Pelo D. Internacional, nenhum privilegio é concedido aọs monarchas depostos. Pelo contrario, um regente goza das mesmas honras que um monarcha. Quando um monarcha está a serviço de um exercito extrangeiro, não goza de honras de soberano. Tornou-se celebre esta distincção no caso Duke of Brunswick. King of Hanover (Phillimore. Oppenheim). Em 1837 o Duque de Cumberilan tornou-se Rei do Hanover; mas continuou Par de Inglaterra. Em 1844, nesse celebre caso, foi reconhecido que, apesar de Rei do' Hanover, como cidadão inglez, como par de Inglaterra, continuava elle sujeito aos tribunaes inglezes.

Presidente. - 0 presidente não é um soberano, é um cidadão que representa o Estado em suas relações 
internacionaes. Não póde gozar do mesmo tratamento que um monarcha, dizem uns (Rivier e Ulmann); pódem gozar, desde que estejam em caracter official (Hall, Despagnet); ou não ha differença entre monarchas e presidentes (Bonfils, Merignaa, Nys, Liszt, Foignet e' Walker). Para mim, comquanto a questão ainda não esteja resolvida, creio que a superioridade de tratamento dada aos monarchas é injusta. Os seus privilegios são obsoletos. O Presidente tendo muito mais valor que o monarcha, deve ser tratado pelo menos, com as mesmas honras que este. Estas são dadas ao Estado, e não ao individuo. Não vejo qual o motivo para que um monarcha por representar ideas antiquadas, tenha maiores previlegios de que um presidente. Ministerio das relações exteriores. Depois da Paz de Westphalia, geralmente o chefe de Estado não negocia com uma potencia extrangeira directamente, antes o faz por intermedio do ministerio das relações exteriores. Assim é definido por Bevilaqua: " é o apparelho juridico politico especialmente encarregado de pôr o Estado em contacto com os outros, de dirigir as relações internacionaes. E' por intermedio do Ministerio das Relações Exteriores, que se regulam as relações internacionaes"

\section{FONTES:}
1) Phillimore, v. 11, $\S 101$
2) Bonfils, n. 632 .
3) Hall, $\S 49$
4) Calvo, 111, $\oint \oint 1,454-1479$
5) Ulmann, $\S 42$
6) Bluntschli, 134
7) Bevilaqua, v. 1, pag. 397
8) Nys, 11 pg. 330
9) Moore, IV
10) Barbalho, art. 34, n. 12 
Ponto 23.

\section{AGENTES DIPLOMATICOS}

Definição. - "Agentes diplomaticos são as pessoas acreditadas pelo governo de um Estado perante o governo de outro, para representar os seus direitos e interesses" (Bevilaqua).

Origem. - Das antiquissimas relações entre as tribus e nações primitivas, originou-se a legação. Antes de existir o Direito Internacional, que se formou na $2 .^{\mathrm{a}}$ metade da Edade Media com Grocio, já gozavam os embaixadores de protecção especial, sendo esta antes religiosa que juridica. Até á separação da egreja do Oriente, os Papas tinham representantes (aprocriarii ou responsales) na Côrte dos reis francos.

Mas estes representantes eram meramente religiosos.

Até o seculo XIII, não existiam legações permanentes.

Começaram então as republicas italianas e principalmente Veneza a adoptar as embaixadas permanentes, entre si. No seculo XV, começaram a ter embaixadas permanentes na Hespanha, Allemanha, França e Inglaterra.

$O$ exemplo foi seguido.

Sómente, comtudo, no Sec. XVII tornaram-se as legações permanentes uma instituição geral, seguindo os Estados o exemplo de Richelieu e Luiz XIV

As embaixadas pérmanentes são hoje de grande importancia, e não se pódem comprehender, as idéas estreitas de Grocio, dizendo que ellas eram inteiramente desnecessarias,

Com a adopção das embaixadas permanentes surgiu a necessidade da diplomacia e dos diplomatas.

"Direito de legação, é o direito que tem um Estado de enviar e receber agentes diplomaticos (Oppenheim)"

Vejamos as ESPECIES de agentes diplomaticos.

Existem em primeiro logar os agentes diplomaticos PERMANENTES E ESPECIAES. 
Depois do Sec. XVI começou-se a distinguir os ordinarios e extraordinarios. No sec. XVIII formou-se a classe dos ministros plenipotenciarios, para evitar questões de precedencia. Como sabemos, estas não cessaram. Pelo Congresso de Vienna (em 19 de março de 1865) estabeleceram-se as classes seguintes:

$\left.1^{\circ}\right)$ embaixadores;

$\left.2 .^{\circ}\right)$ ministros plenipotenciarios e enviados extraordinarios;

3..$^{\circ}$ encarregados de negocios (chargés d'affaires).

O Congresso de Aix-la-Chapelle (1878) creou os ministros residentes. Devemos lembrar ainda os representantes da Santa Sé - Legati a letere e nuncios.

Como começa e como termina.

A situação juridica internacional do enviado começa com a entrega e a acceitação da CARTA CREDENCIAL.

"A missão diplomatica termina:

1. ${ }^{\circ}$ - quando é especial ou temporaria, pela realização de seu objectivo ou pela expiração do tempo fixado para a sua duração;

$2 .^{\circ}$ - sendo permanente, pela retirada do ministro oul sua morte;

3. - em consequencia de mudança na forma de governo, ou pela guerra entre os dois paizes"

Os agentes diplomaticos são objecto do Direito Internacional; gozam, em razão de representarem Estados, de certas honras, ceremoniaes e privilegios, como de extraterritorialidade.

Fontes: - 1. Nys, II pags. 335 e seguintes. - 2. Bonfils. - 3. Despagnet. - 4. Bevilaqua. 1. ${ }^{\circ}$ pags. 401 e seguintes. - 5. Epitacio, pags. 55 e seguintes Codigo - 6 . Twiss, parag. 199. - 7. Moore, Digest - 8. Davis, pags. 190 e seguintes. - 9. Horack. pag. $2-10$. Halleck, cap. VIII. 
Ponto $24 .^{\circ}$

\section{CONSULES}

"Consules são funccionarios administrativos do Estado, que os nomeia, agindo como orgams da politica commercial, e tendo egualmente, por missão proteger, nos seus respectivos districtos, os interesses privados e legalizar certos actos dos cidadãos do Estado, a que servem. (Bevilaqua, 1., pag. 45).

'A instituição consular data da $2 .^{a}$ metade da EdadeMedia.

Nas cidades commerciaes da (Italia, da França e da Hespanha), costumavam os commerciantes designar por eleição alguns mais antigos mercadores, para servirem de arbitros em questóes commerciaes.

Estes denominaram-se juizes ou mercadores consules.

Durante e apoz as cruzadas, os mercadores que ficaram no Oriente adoptaram a instituição consular, com competencia cada vez maior, devido aos tratados (capitulações), feitos entre os Estados europeus e os mahometanos. (Oppenheim, $1 .^{\circ}$ pag. 482; Twiss, $12 \S \oint 253$ - 263; Phillimore, pag. 258; Davis, 212; Halleck, 310; Lorimer, VII).

Mas, com o estabelecimento das legações permanentes, decahiu muito a condição dos consules.

Somente no seculo $16 .^{\circ}$ é que, com o desenvolvimento extraordinario do commercio, começaram os governos a occupar-se seriamente com a instituição consular, objecto de tratados numerosos, que se podem ler em Phillimore, II $\S 255$.

Sendo apenas agentes commerciaes não gozam dos privilegios concedidos aos diplomatas, salvo quando exercem excepcionalmente, funcções diplomaticas. 


\section{FONTES:}

$$
\begin{aligned}
& 1 .^{\circ}-\text { Bevilaqua, I }-459 . \\
& 2 .^{\circ}-\text { Oppenheim, pag. } 482,1 .^{\circ} \\
& 3 .^{\circ}-\text { Nys, II, pag. } 394 . \\
& 4 .^{\circ} \text { - Bonfils, n. } .^{\circ} 731 . \\
& 5 . \quad \text { Calvo, II } \oint 1.368 .
\end{aligned}
$$

\section{Ponto $25 .^{\circ}$}

\section{TRATADOS}

Fontes: - Halleck - 39 e 102; - Davis - 223; Woolsey - 158; Despagnet, n..$^{\circ} 435$; - Nys - III pag. 18; - Hall, pag. 315; - Epitacio, pag. 86.

"International treaties are conventions or contracts between two or more states concerning various matters of interest" (Oppenheim, 1. ${ }^{\circ}$ pag. 540).

" compacts or agreements, entered into by sovereign states for the purpose of increasing, modifynig, or defining, their mutual duties and obligations" (Davis, Int. Law, pag. 223 - V. L. Woolsey, § 101 - Twiss, $\S 224-$ Halleck, pag. 227).

Primitivamente os tratados eram sagrados, antes religiosos que juridicos. A importancia dos tratados começou a tornar-se extraordinaria no sec. XIX, surgindo então ao lado do Direito Internacioal costumeiro, o convencional, muito mais importante.

Os tratados são de varias especies. Não farei a classificação dos tratados, materia em que ainda não se chegou a accordo, apesar de discutida desde Grotio (V Bluntschli, $\oint \$ 433-445$; Westlake, 1 pag. 283; Wheaton, § 268; Ullmann, § 82).

Muito se tem discutido sobre a obrigatoriedade dos tratados. A resposta é a seguinte: os tratados são obriga- 
torios pelo mesmo motivo que o Direito Internacional de que são uma das fontes, pelo consentimento commum. Sobre o consentimento commum já fallámos, e é producto de varias causas: reflexões religiosas, moraes, politicas, etc.

Podem, ser partes em tratados os Estados que são so. beranos, ou os semi-soberanos, na parte em que gozam de soberania.

Como attributo da soberania pode ser feito por soberano, como a Santa Alliança.

O objecto do tratado deve ser:

1. physicamente possivel;

2..$^{\circ}$ moral;

3. conforme com os principios do Direito Interracional, universalmente acceitos.

Contra a opinião de Bulmerincq $(\S 56)$ e de $E$ pitacio (art. 200 Cod.), podemos sustentar com todos os internacionalistas que os tratados não têm forma especial. Geralmente são escriptos, mas podem ser até oraes, como o de Pillan (1697), entre Pedro o Grande e Frederico Brandenburgo.

Não ha differença essencial entre tratados, convenções, declarações ou actos, cuja força obrigatoria é a mesma.

Não havendo uma forma obrigatoria para os tratados, a ordem a seguir nelles é livre. Comtudo a mais usada é a seguinte:

1. 'preambulo (Nome dos Chefes de Estado, de seu representante e motivos do tratado); dos;

$2 .^{\circ}$ estipulações preliminares com artigos numera-

3. $\quad$ estipulações varias (ratificações, duração, etc.);

$4 .^{\circ}$ assignatura dos representantes.

Pode haver um annexo, e parte do tratado pode ficar secreta.

Ainda quanto á linguagem, nada ha de fixo. Antigamente a lingua usada era a latina, ainda hoje adoptada 
pela Santa-Sé. Depois do seculo $170^{\circ}$ o francez tornou-se a lingua diplomatica. Os tratados com a Inglaterra e Estados Unidos são escriptos em francez e inglez, em columnas parallelas. Os feitos com a Porta Ottomana, em arabe e francez (Wharton, $\S 130$; Heffter, $\S 235$; Phillimore, T. II pag. 61; Oppenheim, 1 pag. 439).

Ratificação - é a confirmação final de um tratado, pelas partes contractantes, tratado concluido por seus representantes. Como, em regra só tem força o tratado depois de ratificado, alguns autores concluiram que esta é que constitue propriamente o tratado, e que antes da ratificação existe apenas um desejo de celebrar um tratado (Ulmann § 78 - Nippold, pag. 123; Wejmann I pag. II; Jellineck 1 pag. 55).

Ao contrario, outros com Oppenheim (1 pag. 553), julgam que a ratificação é apenas um exame para saberse si os plenipotenciarios não excederam os seus poderes.

E mesmo a ratificação é regularmente exigida mas não absolutamente necessaria (Oppenheim). A ratificação é feita pelos orgãos competentes do Estado, de conformidade com o seu Direito interno, e só póde ser total. O Estado só poderá recusar a ratificação por motivo grave e justo. (Epitacio). (Sobre a ratificação: Epitacio, art. 203 e seguintes; Bluntschli, §419 — Laurence, § 152 - Klüblr, $\oint 142$ - Hall, $\S 110$ - Wharton, Dig. $\S 131$ - Halleck - pag. - 229 I - II - Lorimer -Phillimore - Oppenheim, 1 pag. 553 - Rivier, II pag. 74).

\section{EFFEITOS DOS TRATADOS}

Temos que distinguir os effeitos dos tratados:

a) para as partes contractantes;

b) para seus subditos;

c) para terceiros. 
Os tratados obrigam em todas as suas partes, impor. tantes ou não, as partes contractantes. Obrigam tambem indirectamente, por meio do Direito Interno, aos subditos das partes contractantes.

Quanto aos terceiros, em virtude do principio, pacta tertiis nec nocent nec prosunt", geralmente os tratados só interessam ás partes contractantes.

Ha tratados que cream direitos para terceiros. Exemplo: Tratado de Hay-Pacencefote, entre a Inglaterra e a America do Norte. (1901) e Hay-Varilla, entre a America do Norte e o Panamá (1903), que estipulava que construido o canal de Panamá, ficaria aberto a todas a nações, comquanto fossem partes nelles unicamente a Inglaterra, os Estados Unidos e o Panamá;

As mudanças de governo, em virtude da continuidade do Estado, não têm influencia nos tratados.

Tratados importantes. - $10^{\circ}$ - Acta final do Congresso de Vienna assignada em Junho, 1815 pela Inglaterra, Austria, França, Portugal, Prussia, Russia, Hespanha e Noruega:

1. ${ }^{\circ}$ - Neutralidade perpetua da Suissa;

$2 .^{\circ}$ - Livre navegação dos rios internacionaes;

$3 .^{\circ}$ - Abolição do trafico de escravos;

$4 .^{\circ}$ - Classes de enviados diplomaticos.

Protocollo do Congresso de Aix la Chapelle:

0 protocollo de 21 de novembro de 1818 cria uma nova classe de agentes diplomaticos.

0 ministro residente.

2) - Tratado de Londres, 1831 - Assignado pela Inglaterra, Austria, França, Prussia e Russia - Art. 7 Neutralidade perpetua da Belgica.

3) - Declaração de Paris, 13 abril 1856 - Inglaterra, Austria, França, Prussia, Sardenha, Russia e Turquia: Corso, bloqueio, etc. 
4) - Convenção de Genebra - 22 agosto 1864 e 6 julho 1906.

5) - Tratado de Londres, de 1867.

6) - Declaração de S. Petersburgo, de 1868.

7) - Tratado de Berlim 1878.

8) -- Conferencia sobre o Congo - 1885.

9) - Primeira conferencia de Haya - 1899.

10) - Tratado de Washington - 1901.

11) - 2. ${ }^{2}$ Conferencia da Paz - 1907.

12) - Declaração de Londres - 1909.

Ponto $26 .^{\circ}$

\section{SOLUÇÃO PACIFICA DOS CONFLICTOS INTERNACIONAES}

1. - As questões entre os Estados podem ser por motivos politicos ou juridicos. Ambas podem ser resolvidas pelo D. I., e assim deve ser. Carta do Dr. João Arruda a Balch (Revista da Faculdade).

Os meios pacificos para solucionar as questões internacionaes são:

1 - negociações entre as partes;

$2+$ bons officios de outros Estados;

3 - mediação;

4 - arbitramento.

Art. 325 Cod. Epitacio:

"Em caso de dissentimento grave ou de conflicto, que as negociaçóes diplomaticas directas não tenham podido resolver, os Estados, antes de qualquer outro procedimento e tanto quanto permittirem as circumstancias, appellarão para os bons officios ou a mediação de uma ou mais nações amigas" 
$10^{\circ}$ - Negociação. - E' o $1 .^{\circ}$ e mais simples. Questão Tejedor (Jm. Nabuco, Um Estadista, III p. 357).

$2 .^{\circ}$ - Bons officios e Mediação. Consistem os bons officios nos tentamens, passos e esforços amigaveis, que uma terceira potencia, extranha ao litigio ou controversia, faz para induzir as partes contendoras a entrarem em negociação interrompida, no emprego de considerações justas e razoaveis para attenuar e acalmar os resentimentos existentes, e ainda na suggestão de alvitres para se chegar ao accordo desejado. Distingue-se da mediação: Nesta o $3 .^{\circ}$ Estado toma parte directa nas discussões. E' mais extensa. $\mathrm{Na}$ practica não se distinguem.

$4 .{ }^{\circ}$ - Arbitramento. "Arbitragem ou arbitramento (arbitrium) é o juizo (judicium) constituido por uma ou mais pessoas individuos ou governos - escolhidos livremente pelas partes contendoras, para decidirem o litigio ou controversia entre ellas existentes" (Lafayette) "Arbitration is when the discusion of a dispute is left to arbitrators chosen by common agreement (Halleck)", "Arbitration is the name for the determination of differences between States trought the verdict of one or more inpires chosen by the parties" (Oppenheim). - Tratado de Versailles: - Arts. 11, 12, 13.

\section{Ponto $27^{\circ}$}

\section{MEIOS COERCITIVOS}

Definição. - "Compulsive means of settlement of differences are measures containing a certain amount of compulsion taken by a State for the purpose of making another State consent to such settlement of a difference as is required by the former" (Oppenheim) Especies: Retorsão, represalia, bloqueio pacifico e intervenção. - Art. 385 Cod. Epitacio. "Nenhum Estado poderá usar de re- 
presalias ou bloqueio pacifico contra os outros. A suspensão das relações diplomaticas, a recusada execução de tratados e embaraços legaes ás relações mercantis são os unicos meios coercitivos autorizados por este codigo" Esta doutrina não é acceita pela maioria dos internacionalistas nem pelo tratado de Versailles (Art. 16) - Não são ainda guerra:

1. - continuam as relações diplomaticas e commerciaes e nada altera a execução dos tratados;

2. - nem todos os meios bellicos são empregados, o que não acontece na' guerra;

3. - conseguido o objectivo termina a applicação dos meios coercitivos, o que não acontece na guerra."Retorsion is the technical term for retaliation for discourteous, or unkind, or unfair and inequitable, acts by acts of the same, or a similarkind" (Oppenheim).

"Reprisals are such injurious and otherwise internationaly illegal acts of one State against another as are exceptionally permited for the purpose of compelling the latter to consent to a satisfactory settlement of a difference creates by its own international delinquency" (Oppenheim) E' fazer justiça pelas proprias mãos.

Bloqueio pacifico: - O bloqueio pacifico consiste em impedir, por meio da força armada, de navios da marinha de guerra, toda communicação com as costas, os portos, ou somente parte das costas e alguns portos de um paiz, ao qual não se declarou guerra.

Historico: - Foi pela 1. a vez empregado em 1827 pela Inglaterra, França e Russia, bloqueando as costas gregas para isolar as tropas turcas. A batalha de Navarino foi o resultado desse bloqueio. As potencias, sustentando que não estavam em guerra com a Turquia, apresentaram condolencias ao Sultão, que ficou muito queixoso. O exemplo foi seguido. - 1831 - A França bloqueia o Tejo. - 1836 - Bloqueio de Nova Granada. (Pela Ing.) 
- 1838 - do Mexico (França). — 183840 - da Argentina (Ing.). - 1840 - 5 - da Argentina (Ing. e França). - 1850 - do Pireu (Ing.). - 1862 - Rio de Janeiro (Ing.). - 1884 - de Formosa (Fr.). - 1893 Menam - (Fr.). - 1902 - Venezuela (Ing., Allemanha, Italia). - 1913 - Antivari (Ing., 'Austria, All., Fr.). - 1916 - Grecia (Aliados). -

Theoria: - "Bloquer un port et protester aussitôt de sa volanté de maintenir la paix, c'est absolument, disait très justement le Reis Effendi aux ambassadeurs de Fr. Angl. et de Russie en 1827, après la bataille de Navarino, c'est abolutement comme si, cassant la tête à un homme, on l'assurait en même temps de son amitié: un pareil procedé, ne serait il pas fou"? - Contra: Bonfis. - Fauchille, Hautefeuile, Gessner, etc.

O Instituto (1874). Condemnou (Haya), bloqueio pacifico. - Em 1887, com tudo admittiu-o (com certas restricções).

OвJесçõEs: $-1 .^{a}$ - E' uma verdadeira operação de guerra;

$2 .^{a}$ - Prejudica a terceiros.

Favoraveis: 1. Lafayette e a maioria dos internacionalistas; $20^{\circ}$ A pratica reconhece a sua legitimidade.

$O$ bloqueio economico é acceito pela Liga das $\mathrm{Na}$ ções: Art. 16.

"Intervention - consists in the dictatorial interference in a difference between two states, for the purpose of settling the difference in the way demande os by the intevening State" (Oppenheim).

Ponto $28 .^{\circ}$

\section{GUERRA - CONCEITO, ESPECIES.}

Esgotados todos os meios para solucionar uma questão internacional, recorrem os Estados, como ultima ratio, á guerra. - Esta é uma instituição legal, regulada 
juridicamente desde Roma. - Adverte Oppenheim que ao expor a sua doutrina sobre guerra estudará, não o que deveria ser, mas sim, o que é na realidade. Este é o verdadeiro methodo positivo adoptado na minha these sobre submarinos de guerra (Revista da Faculdade, 1920). A guerra não é uma illegalidade, é um facto normal na vida dos povos, regulado estrictamente pelas normas do D. I. -

DefiniçÃo: - "War is the contention between two or more States through their armed forces, for the purpose of overpowering each other, and imposing such conditions of peace as the victor pleases", (Oppenheim). Esta é a verdadeira noção de guerra, é a unica positiva. Defensores. - “A paz perpétua é um sonho, e nem ao menos um bello sonho. A guerra é um elemento de ordem universal estabelecido por Deus. Nella desenvolvem-se as mais nobres virtudes do homem. A! coragem e a abnegação, a fidelidade ao dever e o espirito de sacrificio: o soldado dá sua vida. Sem a guerra o mundo ruiria abatendo-se no materialismo" (Mar. Moltke). E assim de Maistre, e outros.

Outras definições: - "Cet état normal d'hostilité qui se substitue aux relations de bonne harmonie de nation à nation ou entre concitoyens appartenant à des partis politiques differents et qui a pour object de conquérn par la force des armes ce qui on n'a pu obtenir par les pacifiques et amiables". (Calvo, Dr. Int.) " the State or condition of governments contending by force" (Westlake)

Os primeiros christãos condemnaram as guerras e os soldados romanos, convertidos ao christianismo não combatiam. Observando-se comtudo que, não podendo os christãos armar-se para defesa propria e dos seus, seriara destruidos pelos barbaros, consultaram Sto. Agostinho. Este defendeu o ponto de vista pratico, e os concilios comminaram excomunhão para os desertores. 
Existem comtudo defensores do principio da paz ou da não resistencia. Assim é de ver a op. Dymond (Essays on Morality). D'accordo com as lições da Theologia. a guerra é um flagello de Deus, com' o qual ameaça os puvos na sua cólera (Levit, c. 26 v. 24; Deut. Cap. 28, v. 49; jerem cap. Y vers 15, .) A religião concorreu muito para abrandar as guerras. - Entre os judeus, a guerra era cruel, como entre todos os povos antigos. Deut. c. 20 e 21 (interessante). Os judeus comtudo nunca aggrediram. Jos. c. 17 v. 13 - judic. c. 1 e 3. - II Paral. c. II v. 17 (Int.).

O Christianismo E as guerras: - Accusam o christianismo de ser a unica religião que armou os homens uns contra outros, que fez esparzir mais sangue do que todas as outras religiões reunidas. E' uma grande mentira:-1. Todos os povos tiveram guerras religiosas; - 2 . $^{\circ}$ Não houve entre os christãos tantas quantas dizem; - $3 .^{\circ}$ Geralmente não foi a religião o principal motivo dessas guerras.

ENTRE TODOS OS POVOS HOUVE GUERRAS RELIGIOSAS. - Os persas destruiram os templos giregos e estes deixaram intactas as suas ruinas para excitar o odio de seus descendentes contra os persas. Disso não se esqueceu Alexandre, que, por sua vez, destruiu os Templos do Fogo na Persia. Zoroastro, percorre a India e a Persia, derramando rios de sangue para estabelecer sua religião. E qual foi o procedimento de Cambyses e Dario-Ocho, no Egypto? Chosroes, rei da Persia, jurou perseguir os romanos emquanto não renunciassem a Christo, e adorassem o sol. Chosroes (em persa Khosrou), succedeu em 531, a seu pae Cobad, da raça Sassanida, guerreou contra Justiniano, Justino e Tiberio II, morrendo aos 79 annos, tendo humilhado os romanos e attacado os christãos. Foi quem trouxe e fa'z traduzir o Kalilah e Dimnath. Luctou contra generaes, čntra como Belizario, e apesar de cruel, como todos os principes orientaes, era favoravel á liberdlade de conscicrcia. 
A guerra sagrada, entre os gregos, durou 10 annos. Os romanos perseguiram, e destruiram o druidismo, nas Gallias. Combateram a ferro e fogo o Christianismo. I os gaulezes e germanos? E os Mahometanos?

A unica expedição militar christã foram as Cruzadas, que alìás tinham uma alta significação politica: Luthero, Calvino, os huguenotes, tinham fins politicos. Era o espirito de independencia, o republicanismo, as rivalidades, o desejo de se apoderarem do poder, etc.: a religião era o pretexto. Os protestantes fallam em favor da Liga contra Henri IV, dizendo que havia nella 3 mil padres, e nenhum philosopho. E em 1789? Quantos philosophos e quantos padres e religiosos?!!! - A religião, pois, não aconselha a guerra, segue apenas a orientação de Sto. Agostinho, que predomina nella. Assim o Direito Internacional não aconselha a guerra, estuda-a como uma realidade, e procura tornal-a menos frequente, menos cruel, mais humana, dictando-lhe leis e regras exactas, e buscando, finalmente, acabar com ella entre os povos, o que é o grande ideal da religião, dos intellectuaes e juristas, internacionalistas e pacificistas, principalmente.

EsPecIEs:- Os militares dividem as guerras em defensivas e offensivas. Os historiadores, em guerra de intervenção, de insurreição, ou revolução, de independencia, conquista, opinião, religiosas, nacionaes e civis. Tambem, os mesmos, em asiaticas, europeas, africanas e americanas; em, antigas, modernas, da edade media e contemporaneas. Os publicitas, em guerras solemnes, perfeitas. imperfeitas, mixtas, não solemnes. As guerras são ainda justas ou injustas. A guerras tomam ainda denominações differentes, segundo os aspectos em que são conside. radas, i. eı., terrestres, maritimas e aereas. -

Males da Guerra. - A guerra é um verdadeiro flagello. Somente o nome guerra indica uma coisa horrivel, como dizia Bosuet. Um homem levado para o 
meio de uma batalha acreditaria que os soldados se batem contra um monstro inimigo do genero humano. Os proprios generaes são os primeiros a se horrorizarem com as guerras e procurarem abrandal-as. Depois da batalha de Fontenoy, o marquez d'Argenson, escreveu a Voltaire: “ le triomphe - parait magnifique, mais le cœur me manque en voyant que le plancher de tout cela est du sang humain"

Depois de Sadowa, 1.200 austriacos feridos ficaram 2 dias em um matto sem nenhum soccorro, e 800 succumbiram depois de lenta agonia. Antes da guerra de 1870, a mais mortiffera, calcula-se queh, só no sec. XIX, morreram 10 milhões de homens em guerras. $\mathrm{E}$ as consequencias? As guerras produzem epidemias terriveis. Já Thucydi. des nos descreve a que surgiu com a guerra do Peloponeso. (430/425 A. C.) Ha a dos Antoninos ou de Galeno, (166-8 A. D.). As invasões dos Imperadores na Italia e as Cruzadas são outros exemplos. Em 963 ou 64 o exercito de Otto I foi attacado pela peste na Italia. O exercito de Henrique IV, em 1081-2-3, foi victima de peste. Em 1137, o exercito de Lothario. Em 1167 o exercito de Frederico Barbaroxa foi destruido por uma epidemia na Italia. Nas Cruzadas, a peste foi um hor. ror, (1097-8). Em 3 mezes morreram 100.000 pessoas. Em 1100 outra peste nas Cruzadas. Na 3. ${ }^{a}$ Cruzada foi uma verdadeira destruição geral. $\mathrm{Na} 7^{\text {a }}$ (1270), entre outros foram mortos Luiz IX e Jean Tristan, seu. filho (?). (Seria dysenteria?) E a lepra na Europa não foi consequencia das Cruzadas? E as epidemias de syphilis no exercito de Carlos VIII? Todas as epidemias de typho coincidem com guerras. 1490, 1528, quando morreram 30.000 soldados, 1552 (Cerco de Metz). Epidemias formidaveis acompanharam a guerra dos 30 annos: typho, peste bubonica, dysenteria. A população da Bohemia de 3 milhóes passou a 780.000 h.! O Ekeitorado da Saxonia perdeu de 1631-2.934.000 pessoas. Wurtemberg de $4.44 .800 \mathrm{~h}$. 
passou a ter 97.300. A população de Hesse diminuiu de'1/4! A população dos theatros da guerra de 300 ficou reduzida a $1 / 2$. A epidemia de typho, consequencia da campanha da Russia (1812), assolou o Centro da Europa. O exercito francez de 20 Out. a 14 Dez. - 812, perdeu 61.964. soldados de febre negra (typho)! Depois da batalha de Leipzig o typho surgiu em Berlim. Esta cidade tinha, em 1813, 155.000 e perdeu em: 18131.1814 e em 1814, 545. Na guerra russo-turca (1828-9), outra epidemia de peste bubonica. Na guerra da Crimiea (18546), epidemias terriveis; só o exercito francez perdeu perto de 18.000 soldados. O mesmo na guerra Civil Ameri.. cana (1861 5): dysenteria, diarrhea, typho, cholera, etc. $\mathrm{Na}$ guerra de 1866, febre typhoide. $\mathrm{Na}$ guerra de 1870 - 1, dysenteria, typho e febre typhoide .. Estalou uma epidemia terrivel na França depois da guerra que destruiu enorme quantidade de gente (variola, smallpox). Na Allemanha tambem a variola devorou milhares de individuos. A variola tambem transportou-se para a Italia, levada por garibaldinos. Assim tambem na guerra russo-turca (1877-8), na guerra contra os boers (1899. 1901), na guerra russo-japoneza (1904-5) e na guerra Balkanica, epidemias terriveis acompanharam as operações bellicas. Na grande guerra, nem é bom fallar, até molestias novas (lamblia) appareceram! E nos cercos de cidades? No de Mantua (1796-7), foi uma coisa tão horrivel a mortalidade que nem é bom recordar. No de Dantzig (1813), as scenas foram dantescas. Da mesma forma no cerco de Torgau (1813) no de Mayença, no de Pariz (1870 - 1) e no de Porto Arthur (1904).

O typho é a praga mais frequente - war-plague. 
Ponto 29.

\section{LEIS DA GUERRA}

Leis da guerra são as normas de D. I. que regulam o modo de guerrear. $\mathrm{Na}$ antiguidade as guerras eram crudelissimas. No começo da Edade Media as coisas pouco mudaram. Nos seculos 15, 16 e 17 as practicas, comquanto menos crueis que as da antiguidade, eram bem ferozes. 0 progresso começou propriamente a fazer-se sentir depois das guerras napoleonicas. Si os Srs. quizerem um resumo da evolução da Guerra, leiam o meu trabalho: $E^{\prime}$ licito o usol de submarinos na guerra?

As leis da guerra são abrandadas pelos principios da cavallaria e pelos principios de humanidade. 0 D. I. escripto sobre a guerra consta dos seguintes elementos: 1) Declaração de Paris — 16 de Abril de 1856; 2) Convenção deı Genebra - 22 de Algosto 1864; 3) Declaração de S. Petersburgo - 11 de Dez. 1868; 4) Convenção de Haya de 1899; 5) Declaração sobre balas dumduum; 6) Declaração sobre explosivos lançados de balóes; 7) Declaração sobre gazes asphyxiantes; 8) Convenção para applicar á guerra maritima os principios da Convenção de Genebra; 9) Convenção de Haya de 1907 sobre abertura das hostilidades; 10) Convenção de Haya de 1907 sobre os negociantes inimigos rompida a guerra; 11) Convenção de 1907 sobre transformação de navios mercantes em navios de guerra; 12) Convenção de 1907 sobre minas submarinas; 13) Convenção de 1907 sobre bombardeio naval; 14) Convenção de 1907 sobre captura; 15) 2 . $^{\mathrm{a}}$ Convenção de 1907 sobre direitos e obrigações dos neutros e individuos nas guerras maritima e terrestre. A origem dessas leis da guerra foram as "Instructions for the government of Armies' of United States in the Field". publicadas pelos Estados Unidos em 24 de Abril, 1863, durante a Guerra do Secesso. Foram redigidas pelo prof. 
Francis Lieber., do Columbia College of New York. E a 1. ${ }^{a}$ tentativa para codificar as leis da Guerra. As leis da Guerra formam-se da seguinte maneira: - procedimentos militares isolados (usus in bello), repetidos, tornam-se costumes e são reconhecidos em tratados, tornandose regras obrigatorias de D. I. As leis da Guerra são obrigatorias para os belligerantes.

Regra: - "En attendant qu'un code plus complet des lois de la guerre' puisse être edicté, les Hautes Parties Contractantes jugent à propos de constater que, dans les cas non prevus dans les dispositions reglementaires adoptés par elles, les populations et les belligerants restent sous la sauvegarde et sous l'empire des principe du droit des Gens, tels qu'ils resultent des usages établis entre nations civilisées, des lois de l'humanité et des exigences de la conscience publique" (Conv. Conf. Haya 1899, e 1909) "Conscience juridique du monde civilisé", diz o Instituto.

Jus NECESSITATIS, DIREITO DE NECESSIDADE, KRIEGSRAson. Alguns autores allemães: reduzem as leis da guerra a simples ideaes, a regras de proceder tão fortes como as da boa educação, da civilidade, do "savoir vivre" Dizem elles que todas as leis da guerra devem ceder á razão de guerra, kriegsrason. Kriegsrason geht for kriegsmanier. Em caso de extrema necessidade as leis da guerra perdem a súa razão de ser e o seu caracter obrigatorio. Esta expressão (kriegsrason) foi, segundo creio, inventada por Kluber, e fez carreira. Dessa opinião são Lueder, Ullmann, Meurer, etc. Para conseguir o fim ultimo da guerra, a victoria, os belligerantes pódem violar todas as leis da guerra. A regra allemã e: "Not kennt kein gebot", a necessidade não conhere lei.

Como observa Westlake si esta doutrina fosse acceita, nenhum dos principios de humanidade, justiça, honra e boa fé, cuja penetração no direito da guerra constitue um dos maiores progressos da civilização moderna, ficaria de 
pé, todos seriam reduzidos a pó. Em caso de necessidade, nãa ha lei, todas são trapos de papel. Argumentam para defender o direito de necesidade, com Grocio. Mas Grocio precisa ser lido de accordo com os principios que prevaleciam no seu tempo. Grocio tambem sustenta que os prisioneiros de guerra poderiam ser reduzidos á escravidão, e que seus filhos eram escravos. Demais Grocio refere-se a guerra justa, e hoje ninguem acceita mais a distincção das guerras em justas e injustas.

Todos os jurisconsultos do mundo culto se revoltam contra semelhante brutalidade: Oppenheim, Westlake, Calvo, Alberto Rolin, Fiore, Bonfils, etc.

Seria o arbitrio, seria voltarmos aos tempos primitivos, á barbaria mais completa.

Ponto $30^{\circ}$

OS BELLIGERANTES (EXERCITO REGULAR, NÃO COMBATENTES, TROPAS BARBARAS, CARACTER DE INIMIGO, ETC.)

Os Estados que tomam parte em uma guerra chiamam-se belligerantes. Sendo o D. I. um direito entre Estados soberanos, só estes são em regra belligerantes. Comtudo, Estados semi-soberanos, neutralizados e insurgentes podem pegar em armas e fazer guerra, tornando-se e sendo reconhecidos como belligerantes. Uma lucta entre Estado suzerano e o vassalo, entre um Estado de uma federação e os outros, é uma guerra no sentido technico, e nella são applicadas as leis da guerra.

Os insurgentes podem ser reconhecidos como belligerantes quando: cional;

1. ${ }^{\circ}$ estão de posse de uma parte do territorio na- 
$2 .^{\circ}$ ) têm um governo proprio;

$\left.3 .^{\circ}\right)$ submettem-se ás leis da guerra.

"Ais forças armadas dos Estados comprehendem:

a) o exercito propriamente dito;

b) as milicias e os corpos de voluntarios que, ostensivamente armados e sob o commando de um chefe responsavel, se distingam alem disto por um uniforme ou signal fixo e reconhecivel á distancia, e nas suas operações se conformem com os preceitos deste codigo referente á guerra.(i. é., com as leis da guerra);

c) as guarnições dos navios e outras embarcações de guerra;

d) as equipagens dos navios mercantes, ou voluntarios transformados em navios de guerra, uma vez que taes navios reunam as seguintes condições:

1. $\left.{ }^{2}\right)$ que estejam sob a autoridade directa, a fiscalização immediata e a responsabilidade do Estado respectivo;

2. ${ }^{a}$ ) que tenham os signaes anteriores dos navios de guerra da sua nacionalidade, o pavilhão militar e a flammula de guerra;

$\left.3 .^{\circ}\right)$ que o seu nome passe a figurar immediatamente entre os destes;

4. ${ }^{a}$ ) que o commandante esteja ao serviço do Estado, haja sido regularmente nomeado pela autoridade competente e tenha o seu nome inscripto na lista dos officiaes da marinha militar;

5. $\left.{ }^{a}\right)$ que observem nas suas operaçóes as leis da guerra; da guerra"

6. ${ }^{a}$ que conservem o seu novo caracter até ao fim (Epitacio, Cod. art. 410) 
Alem das tropas regulares, existem os não combatentes que estão junto dos combatentes.

São: corneios, medicos, veterinarios, capellães, commissarios, vivandeiras, intendentes, jornalistas. Têm uma posição duvidosa.

Veja-se art. 3. do reg. de Haya.

Devem ser tratados como prisioneiros de guerra, quando aprisionados.

Acho que os jornalistas correspondentes de jornaes, de paizes neutros, deveriam ser tratados ainda mais livremente e não serem violentados em caso algum.

De maxima importancia para o Brasil é o seguinte principio: as populações, que se levantam em massa dentro do territorio ainda não militarmente occupado pelo inimigo, para resistir ao invasor, ainda que não tenham tido tempo para se organizarem militarmente, são consideradas como combatentes legitimos, desde que se submetteram ás leis da guerra, tendo chefes responsaveis. Ainda são combatentes legitimos os habitantes de cidades, tomadas pelo inimigo, que antes de lhe prestarem obediencia, levantam-se em massa para expellil-o.

Os franco-atiradores e com maior razão as milicias civicas e batalhões patrioticos, desde que tenham chefe e se submettam ás leis da guerra, trazendo armas ostensivamente.

Quando para resistir ao inimigo que invadiu o solo da Patria a população se levanta em massa, devem as tropas, desder que tragam armas ostensivamente e se submettamı ás leis da guerra, ser tratadas de conformidade com as leis internacionaes, sendo, quando capturadas, tratadas como prisioneiros de guerra.

(Epitacio, art. 411)

(Ver A. Rolin, 276 e segts. v. $10^{\circ}$ )

Deslealdade prussiana. 
Caracter de inimigo: - A guerra é uma relação de Estado a Estado, e não entre individuos. Os subditos dos Estados em lucta não são inimigos, comquanto possa haver repercussões graves sobre suas pessoas e bens. E' barbara a doutrina que torna solidarios com Estados todos os individuos, e sustenta que numa guerra todọs os cidadãos de um Estado são inimigos dos cid'ądãos do outro Estado.

Nos tempos grocianos assim era. Mas, a civiliza. ção e o principios religiosos e humanitarios acabaram com estas praticas estupidas. Já Grocio se revoltava contra o emprego desse principio em toda a sua rudeza. Até hoje na historia ha um clamor de indignação contra os generaes de Luiz XIV, Turenne e Catinat, os devastádores do Palatinado.

Rousseau sustenta que a guerra não é uma relação de homem a homem, mas de Estado a Estado.

Este é o principio acceito por Guilherme I, da Prussia que declarava fazer a guerra aos soldados francezes e não aos cidadãos francezes. 0 mesmo proclamou Wilson e os seus alliados, na grande parada grega, acceitaram os seus principios em proclamações solemnes e successivas. O Estado póde sómente acautelar-se contra os extrangeiros perigosos e os cidadãos de Estado inimigo quet se tornarem perigosos para sua tropa ou para a sua segurança.

"Art. 389. - A guerra, relação de Estado a Estado, não autoriza actos de violencia sinão entre forças armadas dos belligerantes, sendo terminantemente prohibido maltratar as pessoas inoffensivas"

(Cod. Epitacio Pessoa)

Tropas barbaras: 0 emprego de selvagens que desconhecem as leis da guerra é prohibido pelo D. I. O emprego de tropas, de cor, mas civilizadas e disciplinadas é perfeitamente licito. 


\section{Theatro da guerra e região da guerra}

Região da guerra é a porção da superficie do globo onde os belligerantes podem preparar e executar as hostilidades, uns contra os outros.

Theatro da guerra é a parte em que no momento têm logar as hostilidades.

Esta distincção é muito importante.

Os territorios neutros estão fora da região da guerra, e, no proprio territorio dos belligerantes alguma região póde ser neutralizada.

$$
\begin{aligned}
\text { Ex.: - Canal de Suez (1888). } & \text { O estreito de Magalhães (1881). }
\end{aligned}
$$

\section{Ponto $31 .^{\circ}$}

\section{COMEÇO DA GUERRA}

A guerra póde começar, de facto, ou com uma for. mal declaração, ou com actos hostis, considerando-se simplesmente um Estado em, lucta com outro.

Numerosas guerras têm começado sem aviso ou decla. ração prévia, e dahi concluem alguns internacionalistas que a declaração de guerra é perfeitamente dispensavel.

Parece-me comtudo que, em bôa doutrina, é indispensavel a declaração de guerra, em face dos principios do D. I.

\section{Guerras sem previa declaração}

Em 1848 a Prussia attaca a Dinamarca sem previa declaração de guerra; 1875: Servia e Bulgaria; 1894: Japä̀o China; 1897: Grecia e Turquia. A. guerra do Paraguay.

São excepções.

A verdadeira Doutrina. - E' a que sustenta ser indispensavel a declaração da Guerra. 
Lafayette reconhecendo então (1903) não ser ella obrigatoria, accrescenta comtudo: "Cumpre, no emtanto, reconhecer que a opinião segundo a qual a guerra, deve ser previamente declarada, é mais conforme com a razão: consulta melhor a lealdade com que as nações se devem tratar e tem a grande vantagem de marcar com precisão - momento em que começa o estado de guerra" (2. p. 66).

Clovis Bevilaqua (2. p. 281, § 252) Diz:

"As hostilidades devem ser precedidas por uma declaração formal, pura e simples, ou por um ultimatum, notificando a resolução do Estado de romper a guerra. Em qualquer dos casos haverá um prazo peremptorio, entre a advertencia de que vão começar as hostilidades e 0 rompimento effectivo"

Epitacio Pessoa: "A guerra não poderá começar sem aviso prévio e inequivoco, sob a forma de uma declaração motivada ou de um ultimatum com declaração condicional" (art. 386).

E' esta a verdadeira doutrina.

O Instituto de Direito Internacional, (1906), impressionado com o começo da guerra russo-japoñeza, sem prévia declaração (1904), tratou da materia (Alberic Rolin, 1 p. 181). de 1907.

O principio foi acceito pela Conferencia de Haya

E' preciso pois uma formal declaração de guerra. Esta deve constar de um documento escripto, claro e positivo, dizendo os motivos e affirmando o rompimento das relações pacificas.

Depois da declaração de guerra, esta poderá começar immediatamente. De accordo comtudo, com a lealdade estamos com Epitacio (art. 387), em que é razoavel esperar 24 horas para o inicio das hostilidades, depois que a declaração chegar ao conhecimento do governo inimigo. 


\section{ULTIMATUM}

E' a declaração escripta, encerrando as negociações amigaveis, e dando um prazo para a solução de um caso internacional ameaçando de resolvel-o pela força das armlas.

\section{Quem declara a guerra?}

E' questão de D. I. Geralmente é declarada pelo chefe do Poder Executivo.

Na França: Presidente da Republica, com autorização das camaras (lei const. 16-Julho-1875). Estas não o podem comtudo obrigar a fazer a guerra.

$\mathrm{Na}$ Suissa é o Bund (Conselho Federal). De facto, na Europa quem faz a guerra é o poder executivo, pois o contrôle das camaras pouco adianta.

$A$ doutrina americana é muito mais razoavel.

Em alguns Estados americanos só poder declarar a guerra com autorização prévia do Congresso legislativo (Arg. Br. Chile, Colombia, Eq., Rep. Dom., Paraguay, Est. Unidos). Em outros só o Congresso póde declarar guerra, sob proposta do Presidente (Bol, Guat, Haity Mex, NicPan., Perú, Salvador). Na Venezuela pert. ao Executivo.

Const. Braz - art. 48.

Const. Costa Rica o presidente só póde declarar a guerra com autorização do Congr., mas não precisa della para fazer a plaz.

Effeitos: - São effeitos do estado de guerra:

1..$^{\circ}$ attribuir a qualidade de belligerantes aos Estados em lucta, e ás suas forças militares;

$\left.2 .^{\circ}\right)$ romper as relações diplomaticas, sendo egualmente cassado o exequatur dos consules;

$\left.3 .^{\circ}\right)$ resolver os tratados politicos de alliança, de subsidio, e todos aquelles que não tiverem sido, ainda de- 
finitivamente executados (excluidos desta regra oś normativos);

$\left.4 .^{\circ}\right)$ Investir os commandantes militares de poderes necessarios á direç̧ão da guerra.

(Clovis, II p. 272).

Ponto $32 .^{\circ}$

\section{GUERRA TERRESTRE}

O. fim da guerra é vencer o inimigo, e isto é conseguido por meio de força das armas.

$\mathrm{Na}$ guerra terrestre estudam-se os meios de que lançam mãos os Estados para conseguirem o escopo da guerra e a occupação do territorio inimigo.

Estudam-se tambem as questões referentes a: $10^{\circ}$ ) apropriação, utilização e destruição da propriedade inimiga; $2 .^{\circ}$ ) bombardeio; $3 .^{\circ}$ ) assalto; $4 .^{\circ}$ ) espionagem; $5 .^{\circ}$ ) estratagemas.

\section{O QUE É LICITO NA GUERRA}

Pelo art. 22 do "Reg. de Haya" os belligerantes não têm um poder sem limites de attacar. Em geral, podem usar dos meios que não são condemnados pelos costumes ou tratados internacionaes.

Tendencia para abrandar as praticas bellicas (These submarinos).

\section{DIREITO ESCRIPTO SOBRE A GUERRA}

4." Convenção de Haya - 1907 M. imp.

E' a mesma conv. de 1899 aperfeiçoada. Subsidiariamente recorrem-se aos principios de Lieber, aos traba. lhos dos juristas e recorre-se á obra do Instituto de Di. reito Internacional. 
E' preciso não esquecer nunca que ha em Direito Internacional uma tendencia para abrandar as leis da guerra.

As conv. de Haya de 99 e 1909, declararam: “ . En, attendant qu'un code plus complet des lois de la guerre puisse être edicté, les Hautes parties contractantes jugent à propos de constater que, dans les cas non prévus dans les dispositions réglementaires' adoptées par Elles, les populations et les belligerants restent sous la sauvegarde et sous l'empire des principes du droit des gens, tels qu'ils résultent des usages établis entre nations civilisées, des lois de l'humanité et des exigences de la conscience publique"

\section{Meios de fazer a guerra licitos e illicitos.}

São condemnados pelo D. I. todos os actos de violencias contra pessoas que apresentarem caracter de culpa, perfidia ou consistirem em abuso inutil dla força, bem como o uso de meios que tornem a morte inevituavel ou aggravem os soffrimentos dos feridos.

\section{REGRA DE EPITACIO}

Em synthese magnifica, resume o grande jurista brasileiro:

"Art. 415 - Alem das excepções porventura estipuladas em convenções especiaes, ê prohibido: a) empregar contra o inimigo veneno ou armas envenenadas;

b) matar ou ferir á traição individuos pertencentes ao Estado ou ás forças inimigas;

c) pôr a premio a cabeça do inimigo;

d) attacar o inimigo dissimulando os signaes distinctivos da força armada;

e) usar de meios perfidos, taes como: fingir que se rende ou fazer signaes de soccorro para ferir mais de 
perto o inimigo; romper de surpresa um armisticio; faltar á palavra dada; servir-se, por estratagema, do signal do parlamentario, do santo e senha, toque bandeira, insignias militares, ou uniforme do inimigo ou do emblema sanitario;

f) fazer devastações por espirito de vingança;

g) empregar armas, projectis ou materiaes proprios para causar males superfluos, taes como balas explosivas ou que se achatem facilmente no corpo humano, projectis que tenham por fim unico espalhar gazes asphyxiantés ou deleterios;

h) matar ou ferir o inimigo que se rende á discreção ou que está fóra de combate;

i) declarar de antemão que não dará quartel;

j) destruir ou apoderar-se de propriedades inimigas, não sendo isso imperiosamente exigido pelas neces. sidades da guerra;

k) lançar projectis ou explosivos do alto de aerostatos ou por outros meios analogos, emquanto não for possivel fazel-o com a precisão neccessaria para que as populações inoffensivas e os seus bens não sejam attingidos;

1) declarar extinctos, suspensos ou não admissivei: em juizo os direitos e acções dos nacionaes do Estado inimigo"

\section{VENENO OU ARMAS ENVENENADAS}

Todos os escriptores de D. I. condemnam o uso de envenenar o inimigo ou contaminando paços ou cursos d'agua, alimentos ou armas.

(Alberic Rolin, I p. 326 Bonfils-Fauchille, I p. 123; Oppenheim, II p. 161 Woolsey, § 133).

A razão desta prohibição é que o uso do veneno torna a morte infallivel sem contribuir para a terminação da 
guerra, e traz como consequencia a morte de innocentes e não combatentes (Halleck, p. 179).

As instrucções americanas de Lieber art. 70 condem. nam o uso do veneno, e declaram que aquelles que delle usam põem-se fora dias leis e costumes da guerra. Da mesma forma a decl. de Bruxellas de 1877 (art. 13), o manual do Instituto e os regulamentos de Haya de 1899 e 1807, condemnam o uso do veneno sob qualquer fórma que seja.

\section{PRATICAS ALLEMÃS}

Durante a grande guerra os allemães violaram muitas vezes essa regra de D. I. Já não falando da lucta na Africa Austral onde envenenaram varias fontes com arsenico, procurando justificar ainda o seu feio acto (Oppenheim, II p. 171 nota 3, Bonfils-Fauchille, p. 24-v. 2. Garner, I \& 190), na França quando evacuaram os departamentos do Norte, envenenaram numerosas fontes.

Muitas vezes atiraram de aeroplanos bombons envenenados, e tambem envenenavam os generos al menticios que deixavam nos territorios ou trincheiras abandonadas (Pillet, Les conventiones de la Haye (p. 218). Chegaram

- a impregnar de veneno os curativos dos feridos. Semelhante ao uso do veneno é o contagio de molestias. Os allemães espalharam bacillos de fabre typhoide e inoculavam systemlaticamente a tuberculose. Tambem no Brasil, eram os allemães accusados de espalharem gripe na popula. ção.

Quanto ao mormo é coisa liquidada que os allemães o espalhavam sempre.

Segundo um despacho que os Estados Unidos publicaram em 9 de Fevereiro de 1917, informava o chargé d'affaives americano em Bucarest que nos jardins da legação al. lemã foram descobertas numerosas caixas de explosivos e tubos contendo culturas bacillares de carbunulo e mormo que deveriam ser propagados na Rumania. 


\section{GAZES ASPHYXIANTES}

O uso de gazes asphyxiantes é condemnado por trazer soffrimentos inuteis aos combatentes e prohibido pela decl. de Haya de 1899 e artigos. 171 do Tratado de Versailles 135 do de St. Germain e 82 do tratado de Neully. (Ver Garner I $\$ 188 ;$ Bonfils-Fauchille, II p. 120).

\section{AS PRATICAS ALLEMÃS}

Os allemães e seus alliados usaram largamente desse processo barbaro, contrario evidentemente ao art. 23 letra a, citado, e a todas as leis da humanidade.

Essa pratica e o uso de balas dum.dum é um dos maiores horrores da grande guerra.

Levaram os allemães a sua crueldade ao ponto de armlarem os seus soldados de grandes massas de ferro com pontas e baionetas em forma de serrote para acabar os inimigos reduzidos á impotencia pelos gazes, instrumentos que produziam ferimentos horriveis e dolorosissimos.

\section{PÔR A CABEÇA DO INIMIGO A PREMIO}

E' pratica condemnada pelo. D. I. Halleck relata que como ás vezes o exito de uma campanha depende da vida de um soberano ou de um chefe de guerra que, na antiguidade, uma pessoa corajosa ia ao campo inimigo e lá assassinava o adversario. E' o caso de Judith que matou $\mathrm{Ho}$ lophernes. Mas, continua elle, tal acto é hoje considerado infame e execravel, tanto para quem o faz como para quem o manda fazer ("Such an act is now deemed infamous and execrable, both in him who executes, and in him who commands, encourages, or rewards it"), (p. 180).

Lafayette $(\oint 332)$ entre as praticas bellicas condem. nadas como oppostas á moral e ao Direito e offensivas 
dos principios de honra, colloca o " tirar a vida ao inimigo por meio de envenenamento, ou pelo braço de sicario ou assassina á falsa fé ou pôr-lhe a cabeça a premio", e, em nota, cita em seu abono as opinióes de numerosos internacionalistas como Vattel, Martens, Klüber, Heffter, Bello, Phillimore, Riquelme, Bluntschli.

\section{BELLOS EXEMPLOS}

Os consules Caio Fabricio e Quinto Emilio recusaram com horror a proposta do medico de Pyrrho de envenenar o seu senhor.

Alexandre Magno puniu Besso, o assassino de Dario. O proprio Thiberio e o seu Senado acharam perfido o envenenamento de um inimigo, mesmo desleal.

\section{VIOLAÇÕES DO PRINCIPIO}

Na Edade Média ha exemplos de violaçóes do principio, mas, conforme Halleck, provocam hoje horror e indignação, como o assassinato de Guilherme de Orange.

A Inglaterra, ou melhor, o Governo inglez, poz varias vezes a premio! a cabeça de seus inimilgos.

Em 1884 foi posta a premio a cabeça de Osman Digma, mas a indignaação foi universal. Em 1815 Napoleão foi posto fóra da lei pelos alliados!

E, ó infamia incomparavel, em 1914 a Austria-Hungria póem a premio a cabeça de $D^{\prime}$ Annunzio, o altissimo poeta (Journal du Dr. Int, t. XLV, p. 928).

\section{Ponto $33 .^{\circ}$}

\section{GUERRA MARITIMA}

Definição. - A maioria dos internacionalistas define a guerra terrestre como sendo a que se faz em terra e a maritima a que é feita no mar, observa Bonfils (1268), 
mas essa definição não é unanimemente adoptada. $E^{\prime}$ verdade que até agora não surgiu duvida a respeito de ser ama guerra maritima ou terrestre, mas nada impede que, com a crescente complexidade da guerra, surjam duvidas futuras e é bom prevenil-as.

0 Instituto. - 0 art. $1 .^{\circ}$ do projecto de regulamento, redigido por Fauchille, definia inplicitamente a guerra dizendo que o theatro da guerra maritima comprehende: 1) o mar livre; 2) gelfos e bahias, portos e aguas territoriaes dos belligerantes, com os seus estreitos e canaes maritimos; 3 ) aguas continentaes servindo á navegação maritima, contanto que os navios de guerra penetrem nellas pelo mar. Esse texto, como ensina A. Rolin, foi objecto de grandes discussões. Entre outros Hagerup, dizia que: "Ha guerra maritima quando se trata de navios de guerra, pouco importa onde estejam e dêm batalha: o theatro da guerra maritima vae até onde penetram os navios" Afinal a redacção definitiva foi a seguinte, resultado da combinação das proposições de $\mathrm{Ha}$ gerup e Rolin-Jeaquemins: "Les règles de la guerre maritime ne sont applicables qu'à la pleine mer, aux golf'es, aux eaux territoriales des belligerants, y compris les es. tuaires ou embouchures qui sous le rapport de la navigation, sont assimilés aux bais"

A sessão de Oxford. - Em 9 de Agosto de 1914, trava-se em Oxford a discussão, contra a vontade de LyonCaen que a julgava ociosa. Finalmente adoptou-se definitivamente a regra seguinte: "Les règles speciales à la guerre maritime ne sont applicables qu'à la pleine mer' et aux eaux territoriales des belligerantes a l'exclusion des eaux qui, sous le rapport de la navigation ne doivent plas être considerées comme maritimes" Alberic Rolin acha preferivel dizer, "ne sont généralement pas considerés comme maritimes", a dizer, "à l'exclusion des eaux qui, sous le rapport de la navigation ne doivent être considerées comme maritimes" 
Conclusãa. - Acho que se deve levar em consideração para determinar-se o caracter da guerra maritima não só o facto das operações realizarem-se nas aguas consideradas geralmente maritimas, mas tambem o de serem levadas a effeito por forças navaes maritimas.

Prova do asserto. - Em 1795 os hussards do Pichegru apoderaram-se da frota militar hollandesa immobilisada junto do Helder e tomaram Amsterdam em 19. 1 1795. Como é sabido, Amsterdam póde, por meio de seus diques, inundar, num momento, todo o paiz, o que a salvou dos exercitos de Luiz XIV Mas o gelo havia transformado para Pichegru, as aguas em magnifica estrada. Esse caso embaraçoso vem demonstrar a verdade e a necessidade do meu asserto.

Fins da gUerRa maritima e meIos empregados. O fim da guerra maritima é o mesmo da guerra terrestre: vencer o inimigo. Mas, isso é conseguido de modo differente por uma e por outra. Na terrestre conseguese vencendo-se o exercito inimigo e occupando-se o seu territorio. Os fins conseguem-se na maritima pela destruição da armada inimiga e das fortificações de suas costas ou de seus estabelecimentos militares; cortando o commercio com as costas inimigas; defendendo as proprias costas, etc. Os meios empregados são: attaque, capturas de navios inimigos, destruição de navios e bens, bombardeamento da costa inimiga, manhas, estrlatagemas, etc.

Meios licitos. - Em. geral são licitos todos os meios que não são prohibidos pelos usos e tratadost internacionaes, e vedados aquelles que produzem inutilmente ferimentos graves ou incuraveis (Lafayette, vol. 2, p. 174). Bonfils-Fauchille (v. II p. 398, n. 1316), trata aprofundadamente da materia e a elles devem recorrer os estudantes, bem como a Epitacio (Cod. art. 531).

Fontes: - Oppenheim (v. 1l, p. 246) - Taylor, $\S$ 547 - Westlake (11, p. 136) - Depagnet (n. 647) - Nys (111, p. 391) - Bonfils-Fauchille, v. 2 n. 1268. 


\section{Ponto $34 .^{\circ}$}

\section{RELAÇŌES NÃO HOSTIS ENTRE OS BELLIGERANTES}

Comquanto com a guerra rompam-se as relações pacificas entre os Estados, a nècessidade, a conveniencia, a humánidade e outros factos exigem certas relações nào hostis entre os belligerantes. Estas tinham outr'óra, uma sancção religiosa, pois é regra tradicional que - Fides etiam hosti servanda. Hoje, essas relações são reguladas estrictamente pelo D. I. e gozam de uma sanção juridica, alem da puramente religiosa e moral.

Especies. - São numerosas e as principaes resultam dos pactos bellicos (pacta belli), i. é., dos ajustes ou accordos entre os belligerantes acerca de objecto, operação ou negocio de guerra, denominados tambem carteis ( $L a$ fayette, II p. 216). Oppenheim define: "Cartels are convention between belligerants concluded for the purpose of permitting certain kinds of non hostile intercourse between in:em which would otherwise be prevented by war" (II p. 312) -

SusPensão DE ARMAS. - "Denomina-se simples suspensão d'armas a cessação das hostilidades limitada ás immediações de uma cidade ou campo e por breve espaço de tempo (in breve et presens tempus), para fim determinado, como para.uma conferencia, para remoção de feridos, enterramento de mortos ou para esperar ordens de evacuar uma praça" (Lafayette, II p. 216).

Armisticio. - O armisticio é uma convenção mais geral do que a simples suspensão de armas, dum caracter politico ou economico e militar, pela qual os belligerantes combinam suspender as hostilidades ( $V$ Bonfils $n$. 1249-1250 sgts). Clovis o define: “ é a suspensão convencional, temporaria, das operações de guerra" (parag. 275). Lafayette distingue o armisticio parcial do ge. 
ral. Si a suspensão d'armas abrange um maior espaço de tempo, si é por espaço de tempo que vá razoavelmente alem do presente, entra na classe do armisticio parcial. $\mathrm{O}$ armisticio geral, accrescenta elle, tem por objecto a ..ssação de todas as hostilidades de parte a parte sem limite de lugar e sem excepção de forças de mar e de terra: produz de facto a suspensão da guerra, como lucta material, mas a deixa subsistindo como estado juridico; crea uma paz temporaria, ou provisoria, mas não põe termo á guerra, porque continuam por decidir as questôes ou litigios que determinam o recurso ás armas ( $\mathrm{V}$ parag. 392).

Capitulações. - "São as capitulações (pacta deditionis) accordos militares que têm por objecto a rendição ou entrega a inimigo de corpos do exercito, destacamentos, fortalezas, praças, cidades, ou de uma certla regiáo ou parte do territorio" (Lafayette, II, p. 223, parag. 395). - Salvo-conducto. "Salvo conducto (jus commeandi) é a permissão escripta que o belligerante concede a subdito inimigo ou neutro para entrar nos lugares e regióes occupadas por suas tropas, percorrel-as, atravessal-as, ou nellas demorar, livres de prisão, constrangimento ou de qualquer violencia que autorizam as leis e usos da guerra" (Lafayette, parag. $396,2 .^{\circ}$ p. 224). -

Salva-guarda. - Salva-guarda é a protecção que os chefes militares concedem, em bem das pessoas ou da propriedade, dentro dos limites de seu commando, contra os attaques de suas proprias tropas. (Lafayette, II p. 226, parag. 397).

Parlamentarios. - As communicações com o inimigo fazem-se por meio de parlamentarios ou de signaes.

Fontes: - Lafayette, II p. 215 parags. 390 e seguintes. Oppenheim, II p. 303. - Phillimore, III parag. 97 - Bonfils, 1237. 
Ponto $35 .^{\circ}$

\section{O. QUE É LICITO NA GUERRA. GUERRA SUBMARINA. GUERRA AEREA, CRIMES DE GUERRA}

O que é licito na guerra, e guerra submarina. Já tratamos da materia anteriormente e no trabalho é licito o uso de submarinos na guerra. (V Revista da Faculdade)

Guerra Aerea. - 0 emprego de balóes na guerra não é muito moderno. Bonfils-Fauchille traz, quando trata da guerra aerea, numerosos exemplos de empregos de balóes nas luctas entre os Estados (n. $\left.{ }^{\circ} 1440 / 5\right)$. Já em Fleurus, "L'Entreprenant" dirigido por Coutelle, fez grande successo. Sitiado em 1815, Carnot, recorre aos balóes para fazer observaçôes. Mas, como ensinam Oppenheim e Alberic Rolin (Les lois modernes del la guerre, II p. 397), só se pode fallar realmente em guerra aerea depois da guerra italo-turca (1911-1912) Dahi em diante generalizou-se o uso de aeronaves na guerra. Nas guerras balkanicas (1912-1913), na guerra de Marrocos (1914). Mas na guierra mundial é que elles foram largamente empregados como meios de destruição.

E' Licito o USO DE AERoNaVEs NA GUERRa? - A conferencia de Haya de 1899 prohibiu o lançamento de projecteis e explosivos do alto de balóes por cinco annos. Mas, devido ao interesse dos Estados essa prohibição não foi mantida em 1907. Comtudo o art. 25 do regulamento de 1899, foi modificado no sentido de prohibir-se o bombardeio aereo. Podemos responder á pergunta da seguinte forma: 'como a guerra aerea não é prohibida, nem pelos usos e costumes, nem por tratados internacionaes, e como as aeronaves foram usadas nas ultimas guerras, é licito o seu uso, podem ser amplamente empregadas, desde que não venham tornar a guerra mais cruel. Assim as aeronaves podem ser empregadas para observações, transportes, 
etc. Chegamos pois a conclusão do Instituto: "La guerre aerienne est permise, mais à la condition de ne pas présenter pour les persones ou la propriété de la population pacifique de plus grands dangers que la guerre terrestre óu maritime" (Prop. Lapradelle-Mercier, 1911).

Principios a APPlicar. - Na falta de regras especiaes devem applicar-se á guerra aerea os principios da terrestre, quando as hostilidades se realizam sobre a terra, e quando se realizam sobre o mar, os da maritima.

Os HYDRo-AviõEs. - O governo allemão os consider rou navios de guerra; o hollandez e o americano, apparelhos miliatres especiaes, sui-generis, movendo-se nos ares (Nota hollandeza 20-1 Agosto 1914 e Americana 19. ].915)

Os Aeronautas. Bismark os queria tratar como espiões (Nota de 19 de Novembro de 1870). Essa these cruel e absurda é sustentada por Geffken, Heffter, Lueder, Holtzendorf, etc.

A these allemã foi condemnada pela decl. de Bruxel. las de 1874, pelas conferencias de Haya, e pelos maiores internacionalistas do mundo civilizado que proclamam que os aeronautas devem, quando capturados, ser tratados como soldados empregados em operações licitas de guerra. (Davis, p. 299, Snow, p. 90, Hall, Risley, Phillimore, etc.)

Crimes de guerra. - São os actos de soldados ou individuos que podem ser punidos pelo inimigo quando captura quem os praticou.

Especies: - Ou são violações das leis da guerra, commettidas por membros das forças armadas; ou actos practicados por individuos que não são dellas e tambenı a espionagem, a traição de guerra e actos de pilhagem.

Fontes: - Arruda-Submarinos de guerra. Oppen heim (II p. 341) Bonfils-Fanchille n. ${ }^{\circ}$ 1440/5.

Guerra aerea. - Mérignac, Despagnet, Ed. d'Hooghe. Bonfils-Fauchille, II p. 599 n. ${ }^{\circ}$ 1440/5. Traz urmai literatura completa) 
Ponto 36.

\section{NEUTRALIDADE. OS NEUTROS E OS BELLIGE RANTES}

Definição. - "Blockade is the blocking by menattitude of imparciality adopted by third states towards belligerants and recognised by belligerants, such attitude creating rights and duties between the impartial states and the belligerants".

(Oppenheim, II p. 400). "Neutralidade é o estado das nações que absolutamente se abstem de tomar parte directa ou indirecta na guerra de terceiros e mantem para com um e outro belligerante como taes a mais perfeita imparcialidade" (Lafáyette, parag. 402, II p. 233).

Os Belligerantes E os Neutros. - Neutros ou neutraes são os Estados que, rompida a guerra, se mantem no estado de neutralidade. "Os deveres dos neutros resumem-se nos seguintes: intervir amigavelmente, em favor da paz, sempre que as circumstancias o permittirem; não prestar concurso directo ou indirecto á acção dỏs belli. gerantes; não estorvar, por qualquer modo, as operações de guerra realizadas fóra de seu territorio, e impedir que, dentro de seu territorio, se executem actos de hostilidades. A violação desses deveres é acto illicito, pelo qual responder o Estado delinquente" (Clovis parag. 295).

Fontes: - Lafayette, II p. 233 parag. 402. Oppenheim, II p. 283.

Ponto $37 .^{\circ}$

\section{BLOQUEIO}

Definiçấo. - "Blockade is the blocking by menof-war of the approach to the enemy coast, or a part of it, for the purpose of preventing ingress and ingress of vessels of all nations" (Oppenheim, II, p. 511). 
Condições. - São condições da valídade do bloqueio: $10^{\circ}$ - que, declarado por autoridade competente, se limite aos portos e costas do inimigo ou occupadas por elles. $2 .^{\circ}$ - que seja effectivo. $3 .^{\circ}$ - notificado aos neutros. $4 .^{\circ}$ - applicado imparcialmente a todos os pavilhões.

Fontes. - Bevilaqua II parag. 287, p. 365. Epitacio, Cod. Art. 594 p. 265. Bonfils-Fauchille, II p. 939-parag. 1589. Oppenheim, p. 51l. Phillimore, III parag. 285. Fiore, III, 1606. Hautefeuille, II p. 189. Hall, parag. 233.

\section{Ponto 38.}

Contrabando. DefiniçÃo « — "Contraband of war is the designation of such goods as by the belligerant are forbidden to be carried to the enemy on the ground that they enable him to carry! on the war with greater vigour" (Oppenheim, II p. 546). "Contrabando de guerra são os objectos suspeitos, que se destinam ou se presume que se destinam á forças combatentes do inimigo.

Diz-se absoluto, quando consiste em objectos exclusivamente empregados na guerra; e relativo, quando consiste em objectos utilizados na paz e na guerra. O contrabando de guerra está sujeito á apprehensão e confisco: e o navio neutro que o transporta pode ser apresado, e, em alguns casos, tambem confiscado" (C. Bevilaqua, II p. 433-parag. 302).

Fontes. - Lafayette, II parag. 439. Hallechk, II parag. 243. Phillimore, III parag. 226. Despagnet 705. Bonfils-Fauchille, II p. 835 n. 1535.

Ponto $39 .^{\circ}$

Visita e captura de navios. Def. de vislita. "The right of visitation is the right of belligerents to visit and, if 
needs be, search neutral merchantmen for the purpose of ascertaining whether these vessels really belong to the merchant marine of neutrals, and, it this is found to be the case, whether they are attempting to break blockade, or carry contraband, or render unneutral "service to the enemy" (Oppenheim, II p. 604). Os navios de guerra dos belligerantes têm o direito de visitar os navios mercantes dos neutros não só em alto mar como nas aguas territoriaes dos Estados em lucta. O navio mercante neutro póde ser capturado por um vaso de guerra do belligerante: 1. - - si tenta fugir ou se oppõe á visita: $2 .^{\circ}-$ si transporta contrabando de guerra: $3 .^{\circ}$ - si presta assistencia hostil: $4 .^{\circ}$ - si viola ou tenta violar um bloqueio regular. (V Clovis, parag. 310, II p. 455).

Fontes: - Bonfils-Fauchille, II 997 n. ${ }^{\circ}$ 1657. Epitacio, Cod., p. 243 art. 558. Oppenheim, II p. 604 Phillimore, III parag. 322. Hall, parag. 270. Nys, III p. 679. Lafayette, parag. 424.

\section{Ponto $40 .^{\circ}$}

\section{ORGÃOS DELIBERATIVOS INTERNACIONAES}

São os congressos e conferencias internacionaes. "International congresses and Conferences are formal meeting of the representatives of several states, for the purpose of discussing matters of "international interest, and coming to an aggreement concerning these matters" $(O p$ penheim, I p. 644). Não ha distinç̧ão juridica entre congressos e conferencias (Oppenhẹim, I p. 645, Clovis, I p. 513, parag. 151).

Fontes. - Bevilaqua, I parag. 151. Oppenheim, I p. 644. Lafayette, II p. 6 parag. 279. 
Ponto $41 .^{\circ}$

\section{ORGÃOS JUDICIARIOS INTERNACIONAES}

Ha varios tribunaes como o tribunal permanente de arbitragem (Oppenheim, I p. 629), os tribunaes de arbitragem escolhidos pelas nações para resolver as questóes que surgem entre ellas, o tribunal internacional de presas (Oppenheim, I p. 637) e a Corte de justiça internacional. (Pacto da Liga das, Nações, art. 14).

\section{Ponto $42 .^{\circ}$}

\section{A AMERICA E O DIREITO INTERNACIONAL}

O Novo Mundo muito contribuiu para o progresso do direito internacional. A America do Norte por circumstancias excepcionaes tornou-se dentro em pouco uma potencia formidavel, uma das primeiras do mundo. $\mathrm{O}$ Brasil, formado por portuguezes, raça forte entre as mais, resistente, nobre, soffredora e heroica, desenvolveu-se com mais difficuldade, Como expliquei no meu artigo sobre os grandes problemas economicos (Revista da Faculdade), os inglezes encontraram nos Estados-Unidos um solo adaptado, ás culturas da metropole, os portuguezes não: aqui vieram crear tudo, tirar tudo do nada, fazer experiencia de methodo de culturas novas: a civilização americana tem muitos seculos, a brasileira apenas quatro! Eis a causa de não ser ainda o Brasil uma grande potencia mundial. Não nos devemos illudir com o progresso americano, portanto. $\mathrm{O}$ progresso material, desde que não seja acompanhado de perto pelo moral e intellectual, de nada vale. Amo a America do Norte de Black, Cooley, Franklin e Edison, cheia de idealismo, de fé e de bondade, mas não posso supportar o americano metalizado que achincalha a França de Lafayette, que usa tabellas de preço 
para os mais nobres sentimentos. Distingamos o povo dos exploradores do povo. Os americanos cheios de dollars, que vão se émbriagar na França, pregar francos nłas paredes e desfeitear os francezes em sua bella patria, não são os vencedores da guerra. São os profiteurs de la guerre, cobardes e sujos, enriquecidos explorando o suor, o sangue não só de francezes como de seus proprios compatriotas. A America do Norte não póde ser responsabilizada por actos de semelhante corja. $\mathrm{O}$ americano que soffreu nas trincheiras ao lado dos francezes teve os seus sentimentos de solidariedade augmentados, e tem, e não póde deixar de ter, entranhado amor aos seus alliados. A Hespanha cavalheiresca e nobre, synthetizada hoje em Unamuno e Blasco Ibañez, não póde ser responsavel pelos actos de Affonso XIII e Primo da Rivera, a Italia de Nitti, não é a de Mussolini Devemos, poiš, não desanimar, trabalhemos e dentro em breve o Brasil será um dos primeiros paizes do mundo do ponto de vista material, que riquezas e uberdade do solo não lhe faltam. Não devemos invejar ou imitar o progresso de outros Estados: procuremos desenvolver uma cultura, uma civilização puramente nossa, genuinamente brasileira, original e brilhante. E' por esse motivo que sou contrario á immigração. Um povo não é grande qựando tem muitos milhões de almas, como a China, a Russia, ou a India, mas sim, quando tem uma populaçą̃o culta, trabalhadora, civịlizada, que pensa e produz. Temos milhões de braços inuteis no paiz, procuremos aproveital-os. Intensifiquemos - nosso trabalho, aperfeiçoemos os nossos methodo, de cultura, augmentemos a productividade dos nossos habitantes individual e collectivamente. A raça é boa, deve ser aperfeiçoada e aproveitada. Nada de immigrantes, que vêm exclusivamente satisfazer os desejos de plutocratas inconscientes, que venderiam a propria patria a bom preço, que pensam, como disse algures, com o estomagc e não com o cerebro, sentem com os intestinos em vez de scn. 
tirem com o coração. Como em monumental trabalho provou o brilhante jornalista José Bonifacio de Souza Amaral, com a immigração diminuiu a nossa capacidade de trabalho, ella é, pois, por esse e por outros motivos, condemnavel, pelo menos da maneira porque tem sido feita até agora. Procuremos obter, por todos os meios, a democracia e com um bom governo conseguiremos solver os nossos grandes problemas economicos e internacionaes. E' essa a missão que temos, e a Patria espera que cada um cumpra fielmente o seu dever.

As duAs tendencias. - Separadas as nações europeas por seculares rivalidade, no principio do equilibrio europeu, foram ellas procurar a garantia da paz. Na America não, não ha odios nem rivalidades, a politica era, e é ainda simples, e, em dois principios foram basear os Estados' americanos a sua politica internacional: a doutrina de Monroe e o pan-americanismo.

Doutrina de Monroe. - Como já vimos, deante das ameaças de intervenção da Santa-Alliança, Monroe na sua celebre Mensagem de 2 de Dez. de 1823, formula a sua celebre doutrina. Alguns á reduziram á formula: - $a$ America para os americanos. Contem a doutrina duas partes: $1 .^{a}$ principio de não colonização europea. Condemna a intervenção europea na America; 2. ${ }^{a}$ Os Estados-Unidos não intervirão ną politica europea. A AmERICA PARA OS A,MERICANOS. DO NORTE! Eśsa condemnação da interferencia de Estados europeus, transformou-se logo em uma politica de hegemonia, como provaremos dentro em pouco. Oppenheim, o celebre internacionalista, affirma falsamente, que, depois do apparecimento da doutrina de Monroe não houve conquista na America. (II, p. 232) E as ilhas Malvinas? Demais, a America interveio na Grande-Guerra. 0 que querem os americanos é afastar a intervenção europea e firmar a hegemonia, o protectorado americano na America. 
Cuba. - Quando, em 1898, os Estados-Unidos declararam guerra á Hespanha, repudiaram, em resolução conjuncta de suas camaras "toda intenção de exercer uma soberania, uma jurisdicção ou um contrôle qualquer sobre a Ilha de Cuba, excepto para a pacificação", e affíirmaram a "determinação dos Estados-Unidos, de deixarem o governo da ilha ao seu povo, quando fosse feita a pacificação" (Rev. Gen. de D. Int. Publ., 1898653). Proclamada a independencia pelo trat. de Paris (10-12-1898), a Assembléa Constituinte achou qua podia proclamar a soberania de Cuba em termos absolutos (Const. de 1901). Mas, os americanos temerosos de que os cubanos abusassem de sua independencia, não fizessem bom uso de sua soberania, declararam que as tropas americanas só evacuariam a Ilha si uma clausula da Constituição cubana autorizasse a intervenção americana "para garantir a independencia de Cuba e sustentar um governo que garantisse a vida, a propriedade e a liberdade individual" (Reproduzida no art. 3 do trat. de 22-Maio-1903).

Palavras de Roosevelt. - "Si uma nação mostra que sabe agir com raciocinio e decencia nas questóes politicas e sociaes, si mantem a ordem interiormente e cumpre suas obrigações, não deve ter meido da intervenção americana. Perturbações chronicas ou uma impotencia tendo como consequencia o relaxamento dos vinculos que existem em uma sociedade civilizada podem exigir na America, como em outro logar, a intervenção de uma nação civilizada, e no hemispherio occidental a affirmação pelos E. U. A. da doutrina de Monroe, póde obrigalos, apesar de sua relpugnancia, áa agir em uma acção de verdadeira policia internacional" $\mathrm{E}$ mais: " é um verdadeiro truismo dizer que toda nação que quer conservar sua liberdade, sua independencia deve comprehender que tem obrigação de servir-se bem dessa independencia" (Mensagem, 5-12-904). Os americanos, portanto, 
dominaram Cuba pelo mesmo motivo por que os politicós brasileiros não dão ao nosso povo o voto secreto e outras liberdades, de pena: "Coitado! Não está preparado " E, Roosevelt arvóra desassombradamente a bandeira da politica americana: "A America para os americanos.. do Norte" Podemos, comtudo, responder aos americanos que agradecemos muito a sua generosa policia, e que não precisamos absolutamente della.

Palavras de Taft. - A 13 de Janeiro de 1903 o presidente Taft prevenia ao presidente da Republica Dominicana que si as desordens se renovassem em S. Domingos "seria dever imperioso dos EE. UU não ser indifferentes ao restabelecimento da paz e da ordem"

Wilson. - Foi outro grande intervencionista, que via com maus olhos mudanças de governo e governos rèvoluntarios. Deseja extender dia a dia a politicaintervencionista, e chegou a impor após a guerra suas ideas. A Liga das Nações no seu pactó é essencialmente intervencionista

Politica americana. - Escudados na doutrina de Monroe, os Estados-Unidos atiraram-se $(1845,46,48)$ sobre, o Texas, o Oregon e o Yucatan; de 1857 a 60, projetam estabelecer um protectorado sobre o Norte do Mexico, Nicaragua e Colombia; em 1869 e 70, voltam os olhos para a bahia de. Samana e para a ilha de S. Domingos. Em 1903 engolem Panamá. Vêm em seguida as intervenções em S. Domingos, Haiti, Honduras, Nicaragua e Mexico.

Opinião de Root. - “E' uma questão de tempo, o Mexico, a America Central e as ithas que nos faltam ainda no Mar das Antilhas, ficarão sob o nosso dominio O Haiti, o Mexico, a Colombia, Nicaragua e outros Estados da America Central, só poderão prosperar sob o nosso protectorado" (Rev. G. de Dr. Int., t. XXI, p. 460). 
A revolução de 1893. Bonfils-Fauchille, v. I, p. 621, n. 31323, declara: "On doit toutefois signaler qu'en 1893 . 4 l'escadre des E'tats-Unis, mouillée dans la baie de Rio de Janeiro, déjoua, pas son attitude, une tentative de restauration monarchique au Brésil" Têm a palavra os historiadores patrios Conclusão. A doutrina de Monroe é uma doutrina imperalista e de hegemonia americana. A politica dos Estados-Unidos é de absorpção, de conquista: devemos prevenir-nos contra ella.

Panamericanismo. - A idea de que existe entre os Estados americanos uma solidariedade, vinculos indissoluveis, communhão de interesses e de ideas, vem de Bolivar, que, já em 1826, defendia essas idéas panamericanistas no Congresso de Panamá. Tomou grande incremento e celebraram-se varias conferencias panamericanas (1889 em Washington, 1901 no Mexico; 1906, no Rio; em 1910, em Buenos-Aires). O trabalho é enorme: tentase codificar o D. I., funda-se o Instituto Americano de D. I., forma-se o A. B. C. (Argentina, Brasil e Chile), propugna-se o arbitramento, etc.

These Drago. - Sustentou este grande jurista argentino, quando, em 1902, navios inglezes, allemães e italianos vieram cobrar violentamente da Venezuela alguns milhares de contos de particulares, que a divida publica não pode dar logar a intervenção armada, e muito menos á occupação do territorio americano por uma potencia europea.

A doutrina de Tobar, Porter, etc. O exame dessas doutrinas é inụtil. Já estudamos a materia da intervenção, e demos a nossa opinião Devemos nos prevenir contra o imperialismo americano e contra os vendidos a americanos.

Conclusão. - Em synthese: - devemos procurar estreitar os laços de sympathia entre os Estados americanos. Os modos porque se poderá obter esse desideratum estão indicados nos seguintes trabalhos: Dr. João Arruda 
- União Sul Americana, Dr. Braz de Souza Arruda $O$ interesse economico em relações internacionaes $\mathrm{e}$ intercambio intellectual com as republicas americanas (Revista da Faculdade) Só assim conseguiremos a grandeza da civilização americana e a prosperidade brasileira.

Fontes: - Bonfils-Fauchille, v. I, p. 591, n. 312.

Oppenheim, v. I, p. 231.

João Arruda, obra cit.

Braz Arruda, obra cit.

IIImo. e Exmo. Snr. Dr. Director da Faculdade de Direito de S. Paulo.

Communico a V. E. que, em obediencia ás disposições do dec. 16.782-A de 13 de Janeiro deı 1925, art. 149, letra $\mathrm{b}$, expliquei toda a materia, da minha cadeira, providenciando por todos os meios ao meu alqance para que, de accordo com a letra d - do mesmo artigo, o ensino sob minha responsabilidade fosse o mais efficiente possivel.

Ainda mais, no curso die Direito Internacional Publico, o mais completo que já se fez em nossa terra, tratei pela primeira vez, das questões referentes, ao Direito Aereo, ao fundo do mar á radiotelephonia, não fallando já nas explicações que dei sobre as Sociedades commerciaes em D.to Internacional.

Essa minha affirmação é provadá pelo resumo de minhas prelecçốes, que tenho a honra de passar ás mãos de $\mathrm{V}$ E.

Como verá V. E. o methodo de ensino por mim inaugurłado na Faculdade só hoje está sendo adoptado nas principaes Universidades do Mundo, inclusive na célebre Academie de Derit International de ha Haya, em Paris, Harward e Buenos Aires. 
Communico mais a V E. (Art. 149-letra h. dec. 16782 A-cit) que a maior difficuldade encontrada no meu curso foi a má vontade constante dos alumnos em realizar trabalhos praticos, notando-se que se trata dla mesma turma que em 1925, fez as magnificas theses sobre a reforma constitucional, de accordo com o art. 24 do dec. que mereceram tão elogiosas referencias da imprensa desta Capital e do Rio de Janeiro. Acho pois que seria die bom alvitre cumprir-se a disposição do art. 221 letra c) pela qual só podem inscrever-se na $1 .^{a}$ epocha os alumnos que tiverem realizado $3 / 4$ partes dos trabalhos praticos determinados pelo professor da cadeira.

Suggiro mais que se destina para o proximo anno uma verba para que 2 alumnos cursem a Academia de Direito Internacional de Haya, pois reputo vexatorio o que se passou em relação ao assumpto neste de 1926: ficamos abaixo da China, da Persia e do Sião!

Sinto dizer que observei não terem os alumnos um curso regular die preparatorios, e assim pois julgo ser util mais severidade no exame vestibular. Na minha qualidade de professor de Direito Internacional Publico, ligo a maior importancia ao estudo da Historia. Muito trabalho me seria poupado, si os meus alumnos tivessem desenvolvido conhecimento de tal assumpto.

Pasło ás mãos de V. E. a lista dos pontos para a 1. ${ }^{2}$ epocha (art. 228 do dec. 16782-A), para ser approvada pela Congregação.

Reputo pessimo o systhema adoptado pelo dec. 16.782A, mas submetto-me estrictamente ás suas determinações.

Passo mais ás mãos de V E. os documentos comprobatorios das minhas asserções. 